\title{
The Provenance, Use, and Circulation of Metals in the European Bronze Age: The State of Debate
}

\author{
Miljana Radivojević ${ }^{1,5}$ - Benjamin W. Roberts ${ }^{2}$. Ernst Pernicka ${ }^{3}$. \\ Zofia Stos-Gale ${ }^{4}$ Marcos Martinón-Torres ${ }^{1,5}$. Thilo Rehren ${ }^{5,6} \cdot$ Peter Bray ${ }^{7}$. \\ Dirk Brandherm ${ }^{8}$. Johan Ling ${ }^{4}$. Jianjun Mei ${ }^{1}$. Helle Vandkilde ${ }^{9}$. \\ Kristian Kristiansen $^{4}$. Stephen J. Shennan ${ }^{5}$. Cyprian Broodbank ${ }^{1}$
}

Published online: 2 July 2018

(c) The Author(s) 2018

\begin{abstract}
Bronze is the defining metal of the European Bronze Age and has been at the center of archaeological and science-based research for well over a century. Archaeometallurgical studies have largely focused on determining the geological origin of the constituent metals, copper and tin, and their movement from producer to consumer sites. More recently, the effects of recycling, both temporal and spatial, on the composition of the circulating metal stock have received much attention. Also, discussions of the value and perception of bronze, both as individual objects and as hoarded material, continue to be the focus of scholarly debate. Here, we bring together the sometimes-diverging views of several research groups on these topics in an attempt to find common ground and set out the major directions of the debate, for the benefit of future research. The paper discusses how to determine and interpret the geological provenance of new metal entering the system; the circulation of extant metal across time and space, and how this is seen in changing compositional signatures; and some economic aspects of metal production. These include the role of metal-producing communities within larger economic settings, quantifying the amount of metal present at any one time within a society, and aspects of hoarding, a distinctive European phenomenon that is less prevalent in the Middle Eastern and Asian Bronze Age societies.
\end{abstract}

Keywords Bronze Age $\cdot$ Metal $\cdot$ Mining $\cdot$ Provenance $\cdot$ Circulation $\cdot$ Recycling . Trade

Miljana Radivojević

mr664@cam.ac.uk

$\bowtie$ Benjamin W. Roberts

benjamin.roberts@durham.ac.uk

Extended author information available on the last page of the article 


\section{Introduction}

The main objectives of this article are to provide an overview of recent archaeometallurgical research in copper-based metals across Bronze Age Europe and beyond and, through project-generated examples, to show how both old and new approaches and the reinterpretation of results have major repercussions for the interpretation of early metal-using societies of the past. One theme is provenance studies that aim to identify copper-mining centers involved in satisfying the demand for metals in the near and the far and hence tracking the routes of dispersal from the primary producer to consumers. The other main theme concerns the circulation and uses of those same metals, with particular emphasis on the lifetime of units of metal to estimate degrees and roles of recycling and the effects of related technological practice. The focus for the two themes is the production, movement, and consumption of copper-based metals in the European Bronze Age (c. 2500-800 BC), which represents by far the most intensively archaeologically, geologically, and archaeometallurgically investigated period and region in world archaeology. Given the universal nature of the two themes and the advanced state of the relevant scholarship, the paper has a far wider geographical and temporal relevance beyond those aspects that are specific to the European Bronze Age.

During the last half-century, waves of major research projects generated a wide range of perspectives on the archaeometallurgy of Bronze Age Europe (c. 2500-800 BC). The bases for many of these studies are published data lists of compositional (trace element) and lead isotope analyses of metal artifacts and exploited ore deposits. These data have been applied to considering individual objects, hoards, regional assemblages, and even more broadly the circulation of metals across time (as heirlooms, through hoarding, and recycling) and space (through trade and exchange) in Bronze Age Eurasia. However, despite the frequent use of common datasets, a wealth of scientific expertise, and support from numerous funding agencies, there have been very strong disagreements expressed by some key protagonists as to the use, interpretation, and explanation of available data. These disagreements have been aired in a variety of media, book chapters, conference discussions, and journal papers and relate to both methods and interpretations. Such debates go well beyond minutiae of laboratory protocols and greatly matter to the broader archaeological community, both professionals and students, due to the fundamental role of metallurgy and metal objects in Bronze Age research relating to chronological frameworks, subsistence economies, craft specialization, trade and exchange, mobility, warfare, and ritual deposition and social identity (e.g., Anthony 2007; Bartelheim 2007; Broodbank 2013; Chernykh 2013; Fokkens and Harding 2013; Frachetti 2008; Harding 2000; Kohl 2007; Kristiansen and Larsson 2005; Kuzmina 2008; Pare 2000; Vandkilde et al. 2015).

The desire for a more in-depth and constructive academic debate among all those involved led to a small workshop "The Provenance, Use and Circulation of Metals in the European Bronze Age," organized by the two senior authors and held in March 2016 at the McDonald Institute for Archaeological Research, 
University of Cambridge. The trigger for this event was a recent surge in archaeometallurgical projects across Europe and discussions, including opposing interpretations, arising from subsequent publications that targeted long-distance trade of copper in the European Bronze Age or proposed models of metal recycling based on chemical composition of artifacts in this period (Bray et al. 2015; Ling et al. 2014; Pernicka et al. 2016a). The underlying aim of all participants (coauthors here) was to identify how best to acquire, analyze, and interpret extensive archaeometallurgical data for building both small and large-scale archaeological narratives for Bronze Age societies in Europe and beyond.

Two general questions in this respect provided the focus for debate and serve as primary headings in the present article. Where was the metal coming from, and going to, in Bronze Age Europe (c. 2500-c. 800 BC)? What do we know about metal circulation and use in European Bronze Age communities?

Each participant presented and discussed their various research aims, approaches, and results, and although the workshop did not always achieve a strong consensus, it usefully highlighted exactly where agreements and differences exist. This collectively authored paper summarizes the main issues emerging from the discussion, in the hope that they will guide future work within and beyond the study of western Eurasian Bronze Age metallurgy.

\section{Identifying the Key Issues for the European Bronze Age}

Communities across the European continent during the Bronze Age comprised agricultural and pastoral groups living mainly in villages, beyond the borders of the palace civilizations of the East Mediterranean (see Broodbank 2013; Cline 2010; Fokkens and Harding 2013; Shelmerdine 2008). One focus for current scholarly debate lies in the nature of the interrelationships among these communities. There is currently a spectrum of interpretation, ranging from a smaller-scale perspective where economies and identities are perceived as community based and trade and interaction are regional and not yet commodity based (Harding 2013; Kienlin 2015, 2017), to a more global perspective where the Bronze Age is considered an early form of globalization/world system and trade is interregional and commodity based (Kristiansen 2017; Kristiansen and Larsson 2005; Sherratt 2006; Vandkilde 2016). At the core of this long-standing debate is the relationship between European Bronze Age metals and societies, which consequently have been the subject of much scholarship, especially as metals can be used as a proxy for populations, trade systems, conflict, religious practices, and institutional dynamics. Emphasis continues to be placed on the multiple connections between metal objects, metal trade, and elites (e.g., Earle et al. 2015; Kristiansen and Suchowska-Ducke 2015; Vandkilde et al. 2015).

At the broadest spatial and temporal scale of this metal-oriented perspective on the past, Vandkilde (2016) recently argued for the Bronze Age as bronzizationa globalization-like multiscalar process across wide tracts of Afro-Eurasia led by a shared desire for bronze and maintained by innumerable interconnecting activities within and between shifting spheres of interaction. It commenced around 2000 BC and unfolded decisively around c. 1600/1500 BC with tighter and longer 
interconnections; a long phase of shrinkage and growing fragmentation occurred around $1200 \mathrm{BC}$. It also has been argued that metal may have been valued equally across the Bronze Age macroregion regardless of a society's size or status as urban or nonurban, but nevertheless came to be used in culturally distinct and meaningful ways (Wengrow 2011, pp. 136-137). Although there is no consensus on this matter, with potentially too many assumptions rather than systematic analyses, the question it raises of the values placed on metals, and especially bronze, by European Bronze Age societies is fundamental to our debates on metal production, circulation, and consumption.

Within debates concerning metal value, there is frequently too little consideration within many pan-European Bronze Age interpretative frameworks of the substantial differences in metal production, circulation, and consumption across the continent. These differences include technical parameters of metal smelting/alloying and the scale and broader organization of metal production and circulation across Bronze Age Europe. For instance, the large-scale production of copper oxhide ingots from around 1500 BC in Late Bronze Age Cyprus (Gale and Stos-Gale 2005; Stos-Gale et al. 1997) stands in stark contrast to the very small-scale decentralized co-smelting and cementation of arsenical copper and tin bronze that is typical of Bronze Age Iberia (Bartelheim 2007; Rovira 2002, 2007). There are also clear differences between the compositions of some categories of ingots in central Europe (Butler 1979; Junk et al. 2001), Mediterranean oxhide ingots (Stos-Gale 2000), high-lead Armorican socketed axes (Briard 1995), and contemporary, and even contextually associated, finished bronze objects whose inbuilt potential was to end up as "ingots." Finally, within the shared propensity for sacrificial hoarding in non-Mediterranean Europe, there are also considerable variations across the depositional practices of metalwork, presumably due to varying rationales locally and regionally (Bradley 2017; Fontijn 2002; Hansen 2013; Dietz and Jockenhövel 2016; Milcent 2012; Wiseman 2018). The recovery and recording of Bronze Age metal objects by archaeologists, of course, also varies with national heritage, research traditions, and legal frameworks (Murgia et al. 2014; Novaković et al. 2016; Webley et al. 2012).

At the general level of academic practice, there is widespread agreement on the need for greater emphasis on the sharing of data, especially given that much of the scholarship depends on large datasets and addresses issues of pan-European connectedness and mobility. Ideally, all data, legacy and new, should be published, as was done with pioneering projects such as the large-scale studies of Otto and Witter (1952), another project organized by the Ancient Mining and Metallurgy Committee of the Royal Anthropological Institute (Case 1954; Coghlan and Cook 1953), a large-scale study of Copper and Bronze Age metal artifacts in the Balkans led by the Russian Academy of Sciences (Chernykh 1978), and the Studien zu den Anfängen der Metallurgie (SAM) project (Junghans et al. 1954; 1960, 1968, 1974) and its successor, The Stuttgart Metal Analysis Project (SMAP) (Krause and Pernicka 1996). The latter assembled some 35,000 compositional analyses of prehistoric metal objects, including 22,000 from the SAM project that were converted into digital format, together with approximately 5000 from the Max Planck Institute for Nuclear Physics in Heidelberg (E. Pernicka), around 2000 from Otto and Witter (1952), and a few thousand more compiled from the literature by H. Schickler of 
the Württembergisches Landesmuseum in Stuttgart. The work of numerous scholars at the British Museum has contributed several hundred chemical analyses of metal objects relevant to these discussions (Craddock 1976, 1978, 1985). A pioneer in creating an online open access repository in this field is the Oxford Archaeological Lead Isotope Database (OXALID) published by Zofia Stos-Gale (Table 1). Also, some 26,000 analyses were classified with average-link cluster analysis by Pernicka (1990), which formed the basis for an archaeological evaluation that includes the database in digital format (Krause 2003). Several studies have thrived on these databases of metal compositions, which come alive through dialogue with the objects and their contexts (e.g., Bray and Pollard 2012; Lorenz 2010; Rassmann 2011; Vandkilde 1996). The influence of SAM and other pioneering projects on subsequent major archaeometallurgical investigations of early metallurgy, notably the Arqueometalurgia de la Península Ibérica project (Table 1), is strongly evident (Montero and Delibes 1999; Rovira and Gómez Ramos 2003; Rovira et al. 1997).

However, it is not yet common that access to archaeometallurgical data is facilitated by open access platforms beyond some "big" journals (e.g., Archaeometry, Journal of Archaeological Science); analytical data often get published in conference proceedings, local journals, and other publications that may not always reach wide circulation (cf. Pearce 2016). With the advancement in analytical techniques over the past decades, it is also fair to point out that some of the produced data need

Table 1 List of projects and associated websites mentioned in the text

Project title Website

An archaeological fingerprint: Isotopes as a key to trace Denmark's metal supply and routes of transfer in Early Bronze Age (2100-1500 BC)

Arqueometalurgia de la Península Ibérica

Extraction of copper in Sweden during the Bronze Age? Possibility, myth or reality?

Flow of ancient metals across Eurasia (FLAME)

Oxford archaeological lead isotope database (OXALID)

Reproducibility initiative

Scandinavia's role in the copper networks of Europe in the 2nd millennium BC

The Pile in Scania project with focus on the period around $2000 \mathrm{BC}$

Tin isotopes and the sources of Bronze Age tin in the Old World (BronzeAgeTin)

Travels, transmissions and transformations in temperate northern Europe during the 3rd and 2nd millennium BC: The rise of Bronze Age societies

Must Farm
https://goo.gl/RiEnwU

http://humanidades.cchs.csic.es/ih/paginas/arque ometalurgia/apipro.htm

http://historiskastudier.gu.se/english/research/extra ction_of_copper_in_sweden_during_the_bronz e_age

http://flame.arch.ox.ac.uk/index.html\#home

http://oxalid.arch.ox.ac.uk

http://validation.scienceexchange.com/\#/reproducib ility-initiative

http://historiskastudier.gu.se/english/research/scand inavian-role-in-copper-networks

n.a.

http://www.cez-archaeometrie.de/?p=1028

https://the-rise.se/

http://www.mustfarm.com/ 
to be critically reassessed, whether in light of analytical improvements or an associated contextual/archaeological (re)interpretation. Noteworthy here is the Reproducibility Initiative (Table 1), a platform set up for independent validation of experimental and other results (though mostly aimed at the life sciences), which also serves as a reminder of an ethical obligation to make such data available in a timely manner, given that scholars in our field work with public heritage materials and almost exclusively using public funds. Most EU countries now have policies, even demands, in place for data management and open access and open source publication of data.

While publication of full datasets including all relevant metadata and associated information is imperative, we emphasize here the need for the fuller acknowledgment of prior scholarship, in Europe as much as worldwide, relating not only to the production of primary data but also to the interpretation of that data, particularly referencing work done outside English-speaking countries. Considering previous approaches and their internal logic, whether agreed with or not, strengthens current debate. It is also important to put previous scientific programs into the context of their contemporary reception and recognize innovative advances both in the past and the present. This is why, in the system where (legacy) data stand for a proxy of past human behavior, we encourage diversity in both instrumental and interpretative approaches.

There is also a need for greater clarity in the description of the methods used and a justification as to why they were used. Furthermore, it is important to document and publish the place where the sample has been taken from a studied object. Publication of the weight of metal objects also is crucial for closer evaluation of the quantity of metal trade and circulation, discussions of standardization of production, and the emergence of weight systems. Finally, greater rigor is required in the presentation of quantitative data, including analyses of reference materials and full datasets. For instance, while it may be appropriate to discuss average values for series of chemical data, presentation of the shape of the distribution of compositional data, the statistical significance, or the standard deviation add significantly to the clarity and quality of analytical undertakings. For dealing with isotopic data, Kernel density estimate (KDE) contours (e.g., Charlton et al. 2012), isotope mixing models (Pernicka 1990; 2014; Pollard and Bray 2015), or calculated Pb model ages (Albaréde et al. 2012), may provide useful complements or alternatives to the wellestablished lead isotope ratio biplots.

Requirements for sample sizes have continuously been reduced due to the advance of analytical methods. However, for reliable bulk analysis of archaeological metal objects, it is advisable to obtain a representative sample. Craddock (1976) discussed this in some detail and suggested to extract a sample by drilling with a 1-mm diameter drill to a depth of $1 \mathrm{~cm}$ to ensure that enough material is obtained so that the sample is representative of the whole. This would be equivalent to about 80-100 mg sample mass, while the SAM team routinely used $40 \mathrm{mg}$. However, Pernicka (1984) found no difference between sample masses of $40 \mathrm{mg}$ and down to $3 \mathrm{mg}$ using remaining material from the SAM study. Today even smaller samples collected by laser ablation may prove useful (Walaszek et al. 2013), but this certainly applies only to small objects that cooled quickly enough upon casting so that no segregation of their particular components was possible. With the development 
of portable X-ray fluorescence (XRF) instruments, it became possible to perform noninvasive analyses directly in the museum collections. However, this method yields information only on the composition of the surface, which in most cases is not representative of the whole object, due to effects of patination and corrosion, among others. If patinas can be removed, however, XRF allows for relatively inexpensive analyses of many objects, which may allow for more representative overall pictures of compositional trends. For lead isotope analyses, only very small samples are needed: a few milligrams of material with a few parts per million (ppm) of lead are usually sufficient. The samples can be taken from the surface, providing that there is no contamination with lead from the environment. Overall, rather than an absolute "best" technique, their choice needs to be assessed against the questions being asked, although the use of various techniques does render efforts of data pooling for reanalysis more challenging.

At this point we emphasize that the choice of artifacts for analyses also may significantly affect the narratives we construct on the basis of provenance. There may have been different spheres of metal circulation, partly overlapping in space and time but catering to different functional or social needs, hence the typology and context of the objects analyzed may have a strong bearing on the resulting picture (cf. Rehren and Pusch 2012). Rather than focusing on individual objects that may prove that some "contacts existed," we should investigate the nature, scale, and actual significance of such contacts. For this, a rigorous approach to sampling is required, both in the selection of objects to be analyzed and the sampling spot and size itself. This is not always possible owing to curatorial or other constraints, but at least researchers should be explicit in acknowledging their sampling frames and any potential biases in their sample selection.

\section{The "Provenance Question" in Bronze Age Europe: Where Was the Metal Coming from and Where Was It Going?}

The fundamental question in provenancing Bronze Age metal objects to the specific ore deposits or regions of origin continues to be addressed by comparing the results from both trace element and lead isotope analyses of the metal objects and the potential ore sources. However, provenance studies are only one part of the scientific characterization of an analyzed (metal) object, for which the source of the ore is only one component of the provenance. With mines as the natural starting point of metal entering circulation, the "provenance" label can take on a variety of layered meanings, including from where ancient craftsmen acquired their metal and from which workshops consumer groups obtained their objects (Pernicka 2014; Pollard et al. 2014). After the discard or burial of an artifact, the provenance question can have answers ranging from the exact archaeological context or grave group to subsequent ownership and potentially illicit sales (Rehren 2016, p. 257). With a focus on the material origin of the metal, the identification of supply networks of raw materials could be addressed through the application of agent-based modeling, spatial analyses, or complex networks analyses, all of which would ideally match the chemical groupings of metal artifacts and metal production evidence with networks 
of acquisition and circulation (Ducke and Rassmann 2010; Perucchetti et al. 2015; Radivojević and Grujić 2017). The time element of these metal movements also needs to be considered, so that changes of ore and metal supply over time become evident. The provenance analyses thus contain interpretative powers that, in combination with other analytical techniques, should allow us to characterize the more complex socioeconomic processes indicated in the metal movement (cf. Bray et al. 2015; Pernicka et al. 1990; Pollard and Bray 2014).

The challenges and possibilities of scientific provenancing were recognized early on in trace element analyses by a range of research groups. These include pioneers such as Otto and Witter (1952), Pittioni (1957), Coghlan and Case (1957), and the authors of the largest program of pan-European Bronze Age compositional analyses - the SAM project (Junghans et al. 1960, 1968, 1974). The SAM authors explained that, in their view, the identification of the geological source of the metal would not be possible due to the large number of analyses required to characterize all known copper deposits and smaller occurrences in Europe. Instead, since it was thought that the complexities induced by the smelting of ores and (re)melting of metals would anyway make it difficult to relate metal objects to specific ore sources, the project sought to identify compositional groupings of metal objects to study their distribution in space and time. Among other aspects, critics claimed to have detected weaknesses in the statistical approach employed by the SAM project (see below). The later introduction of the determination and interpretation of lead isotope abundance ratios to questions of provenance also requires the exercise of caution, as discussed below (cf. Pernicka 1990; 2014; Stos-Gale 2016). There is currently no technique of direct provenancing in metallurgy comparable to geologically distinctive lithics such as obsidian (e.g., Tykot 2002) or jadeite (Pétrequin et al. 2012).

\section{Provenance Techniques}

The use of lead isotope (LI) data in archaeology relies on the unique property of lead to be characterized by its isotope abundance ratios in an ore deposit (Gale and Stos-Gale 2000), which is associated with the average terrestrial "ore-lead" at the time of mineralization (Loveless 1975). Since three of the four lead isotopes continuously form from the decay of uranium and thorium in the Earth's crust, this ratio constantly changes. Most ore-forming processes physically separate the "mother" elements uranium and thorium from the accumulated crustal lead, which is then concentrated in an ore deposit within which no further changes in the LI ratio occur. Interpreting the LI data has been challenging because ore deposits that formed at the same geological time in different locations might have very similar ranges of lead isotope abundance ratios. Also, the LI data are highly correlated for geochemical reasons, and it is therefore more difficult to group them into distinctive clusters than in the case of trace element data.

The main strength, therefore, of the application of LI analyses in archaeology is that the LI ratios in metal artifacts of interest can determine definitely where the metal could not have come from. However, a positive match of the LI ratios of a metal artifact with the LI ratios of a potentially relevant ore deposit (in terms of 
geography and geochemistry) may indicate the source from which that metal could have originated. The term often used when the LI abundance ratio data of an artifact and an ore source correspond is that LI ratios for an object are consistent with a potential source (Pernicka 2014). Yet, we can be confident about a possible relation between an artifact and an ore deposit based on LI analysis only when we can exclude all other potential sources.

Thus, the process of interpretation for these kinds of data is a complex search for overlapping patterns on a diagram; today we build on just under 10,000 published LI datasets for samples of copper and lead/silver ores (many of which also include their geochemistry and exact location in the deposit) and several thousand European Bronze Age metal artifacts. This estimate is based on the data available via OXALID (Table 1) and in published articles, many of which have been cited here. Judging the possibility of whether a specific metal sample originates from a given ore source relies not only on the comparisons of the LI ratios, together with the chemical composition, but also (and most importantly) on testing the provenance hypothesis against archaeological and archaeometallurgical information from the region of interest (e.g., Artioli et al. 2016; Höppner et al. 2005; Hunt-Ortiz 2003; Pernicka 1990; Pernicka et al. 1997; Rohl and Needham 1998; Stos-Gale 2016). The importance of testing the provenance hypothesis against archaeological and archaeometallurgical information still needs to be strongly emphasized to avoid poor practice in lead isotope data interpretation, such as the recent suggestion that the tin and/ or bronze for mid-second millennium BC Chinese leaded tin bronzes originated in southern Africa, or indeed the Sahara (Sun et al. 2016). Suffice it to say that neither tin bronze artifacts, nor any other copper alloys, were known or made in southern Africa or the Sahara at that time, nor is there any indication of contact between Africa and China during the mid-second millennium BC (S. Liu et al. 2018).

Physico-chemical and metallurgical considerations (Pernicka 1987, 1999) and experimental data (Merkel 1990; Tylecote and Boydell 1978) have shown that the trace element pattern of copper does preserve some chemical information from the ores of which it was made. The rationale for establishing a provenance with trace element analysis is very similar to LI analysis: it mainly serves to exclude possible ore sources under consideration. Importantly, isotopically overlapping sources may sometimes be distinguished by their trace element pattern and vice versa (Rohl and Needham 1998). However, it is obvious that the analyst must consider archaeological context and the technological history of the object of interest, which may include remelting, mixing, and so forth. Ideally, as many data as possible should be brought to bear on these complex problems, because chemical and isotopic datasets together provide more discrimination between ore sources than either one alone, and they are fundamentally strengthened by careful dating and archaeological context.

There are, however, many fewer data in the literature on the chemical composition (trace element) of ore deposits than there are LI analyses. This is mainly due to the fact that most ancient ore deposits have been mined in more recent times, and it is often difficult to obtain representative samples of ore that could have been accessible to prehistoric miners. The LI analyses do not face such a problem because the LI ratios are normally the same within different minerals of an ore deposit, while for trace element analysis it is not only necessary to obtain relatively large samples of 
ore for chemical analysis but also as many as possible to characterize an ore body that may be several hundred meters in extent. Generally, the knowledge of economic geology and concepts of ore genesis and ore provinces is helpful in this discussion. Furthermore, while the largest datasets of LI analyses are very accurate and can therefore be pooled together, this is often not true for chemical analyses, not only for ores but also for artifacts (Chase 1974). Even in cases where we can assign an artifact to a geological source with some confidence, this link does not always and necessarily represent a direct archaeological connection between both locations: knowledge, materials, and people may circulate on different pathways and timescales-a point explored in more detail in the following section.

It is within this context that the recent development of tin isotope analysis-currently by the ERC-funded, Tin Isotopes and the Sources of Bronze Age Tin in the Old World (BronzeAgeTin) Project (Table 1) - may enable small variations in the tin isotope abundance ratios of the tin sources of Bronze Age bronze objects to be identified. The pioneering application of tin isotope analysis on the Nebra Sky Disc found in Germany indicated that the tin within the bronze did not derive from the relatively close tin ores in the Erzgebirge (Figs. 1 and 2) but instead is consistent with ores in Cornwall in southwestern England (Haustein et al. 2010). Further experiments on the loss of tin during smelting and casting suggested that the fractionation is small but measurable when compared to the variation of tin isotope composition within a deposit (Berger et al. 2016, 2017; Brügmann et al. 2017), which indicates that the tin provenancing method is reliable; however, thus far little is known about potential fractionation during pouring or re-melting under variable redox conditions, as typical of prehistoric technologies, which might pose a challenge to the potential of the method (see also Balliana et al. 2013; Mason et al. 2016).

\section{The SAM Project and Its Impact}

When the SAM project was published, many archaeologists questioned the meaning of the compositional groups, which were often criticized especially in the northwestern European literature (e.g., Coles 1970; Liversage 1994; McKerrell and Tylecote 1972; Tylecote 1970; Waterbolk and Butler 1965). Besides criticism of the analytical approach and the validity of small sample size, which has been refuted by Pernicka (1984), a major criticism regarded the reasoning and methodology behind the statistical grouping of data. Namely, the SAM project used analysis of variance and frequency analysis to identify chemically similar groups of artifacts, a precursor to later multivariate approaches (Junghans et al. 1954). Pernicka (1990) reported good correlation of these with average-linkage cluster analysis on log-normally distributed data. The rationale behind this approach is the fact that minor and trace elements are log-normally distributed in nature and that the physico-chemical laws governing the processes involved in the production of metals are multiplicative, which implies that a log-normal distribution of minor and trace elements in the final products (metal artifacts) is expected.

The meaning of the SAM compositional groups was clearly outlined by Sangmeister (1971): metallurgists will produce compositionally similar metal, if they 


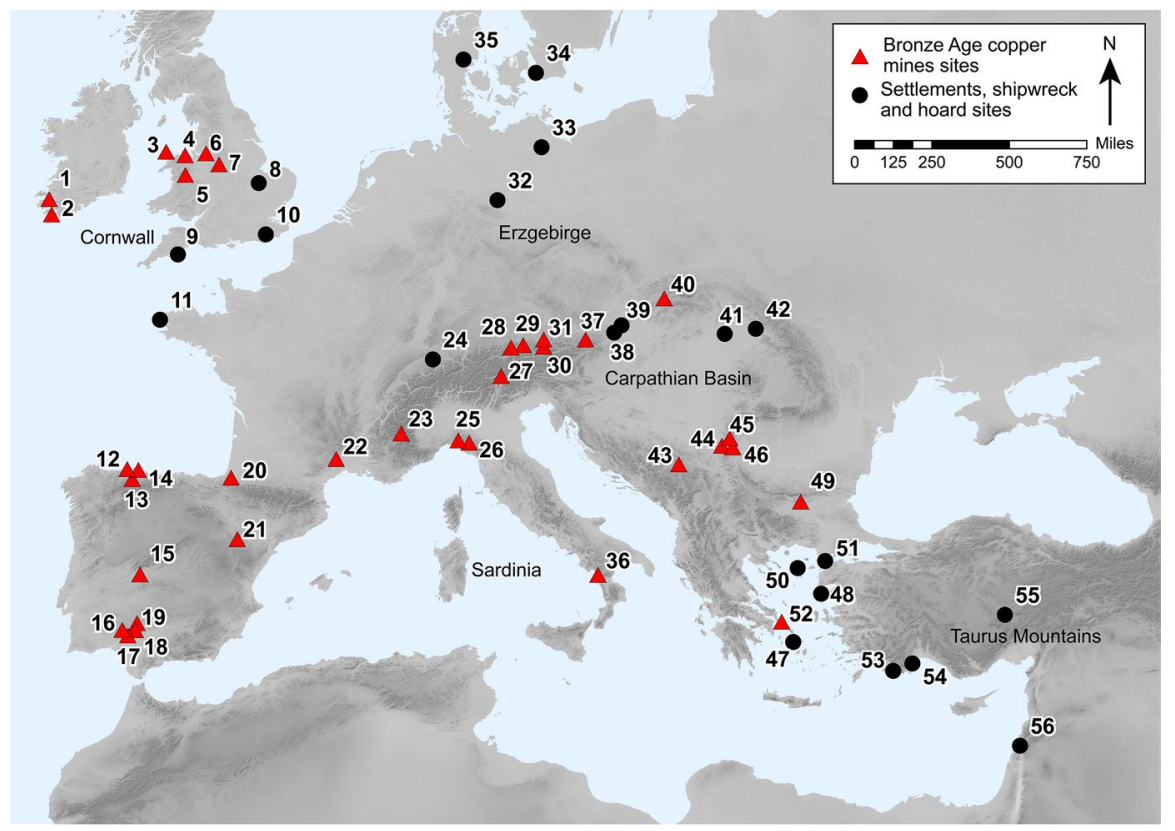

Fig. 1 An overview of Chalcolithic and Bronze Age copper mines $(\Delta)$ in Europe together with settlements, shipwreck, and hoard sites mentioned in the text (o). 1, Ross Island; 2, Mount Gabriel; 3, Parys Mountain; 4, Great Orme; 5, Cwm Ystwyth; 6, Alderley Edge; 7, Ecton; 8, Must Farm; 9, Salcombe; 10, Langdon Bay; 11, St Renan; 12, El Aramo; 13, La Profunda; 14, El Milagro; 15, San Cristóbal de Logrosán; 16, Cuchillares; 17, Chinflón; 18, La Loba; 19, Berrocal; 20, Causiat; 21, Loma de la Tejeria; 22, Cabrières; 23, St. Véran; 24, Sursee-Gammainseli; 25, Libiola; 26, Monte Loreto; 27, Trentino; 28, Schwaz-Brixlegg; 29, Glemmtal; 30, St. Veit; 31, Mitterberg-Bischofshofen; 32, Nebra; 33, Tollense; 34, Pile; 35, Egtved; 36, Grotta della Monaca; 37, Eisenerz; 38, Mannesdorf; 39, Hainburg; 40, Špania Dolina; 41, Hajdúsámson; 42, Apa; 43, Jarmovac; 44, Ždrelo; 45, Majdanpek; 46, Rudna Glava; 47, Kastri; 48, Thermi; 49, Aibunar; 50, Poliochni; 51, Troy; 52, Lavrion; 53, Uluburun; 54, Cape Gelidonya; 55, Kanesh; 56, Nahal Mishmar

always acquire their raw materials from the same source, always mix different raw materials in the same proportions, and use the same smelting and refining technologies. Thus, the SAM compositional groups may be regarded as representative of production centers or regions that draw on specific ore sources. Furthermore, the SAM study also considered the typology of artifacts together with the compositional groups they produced, as best exemplified in the identification of a specific metal type related to the Early Bronze Age neck-rings with flat-hammered rolled ends (the so-called Ösenringe, see Fig. 3) (Junghans et al. 1968; Vandkilde 2005).

Some criticism of the SAM grouping system discusses the appropriateness of data clustering approaches for characterizing copper-alloy metallurgy, such as the logic behind trying to identify distribution patterns of elemental concentrations in the data and linking these with ore sources. Waterbolk and Butler (1965) and McKerrell and Tylecote (1972) both critiqued the concept of identifying log-normal distributions within elemental data, arguing that normal metallurgical processes would 


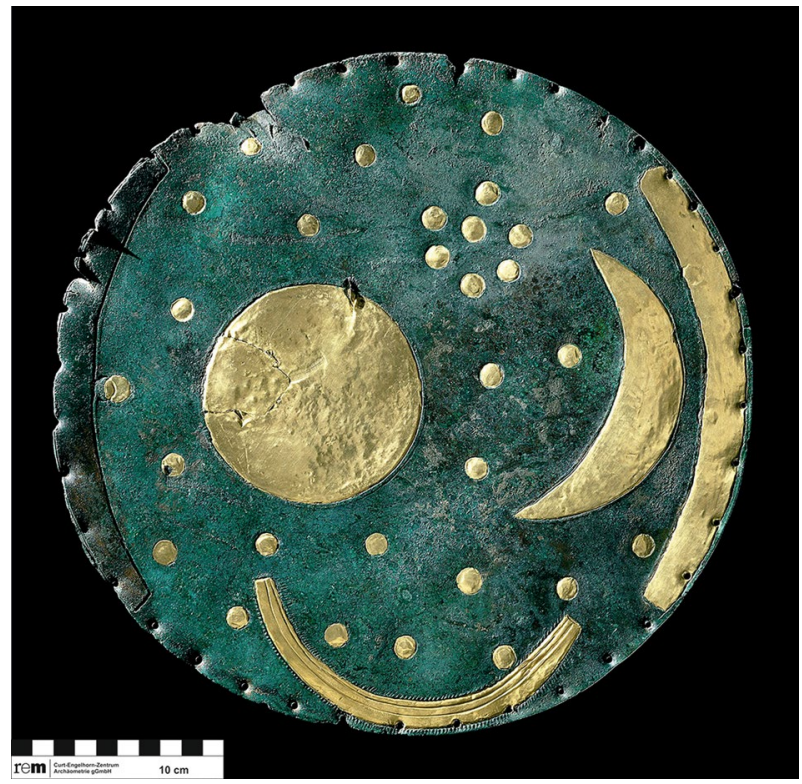

Fig. 2 The Sky Disc of Nebra, the earliest astronomically correct representation of the night sky (Copyright: Landesamt für Denkmalpflege und Archäologie Sachsen-Anhalt, Juraj Lipták)

alter and mix chemical compositions. Waterbolk and Butler (1965) encouraged the use of histograms of the concentrations of the same four elements the SAM study used (As, Sb, Ag, Ni) to characterize the nature and history of the Early Bronze Age copper alloys, but they also used logarithmic concentrations. Härke (1978) showed that both approaches resulted in similar compositional groupings, a finding subsequently echoed by Vandkilde $(1996,2017 a)$, who showed that at the onset of the Nordic Bronze Age, broadly the same copper groupings reappear regardless of the statistical method employed (so-called Ösenring, Ösenring++, and Singen-like copper, see also Fig. 3). In his review of the debate, Liversage (1994) questioned the compositional groupings of SAM, expressing doubts regarding their validity in the precomputer era; nevertheless, he, too, used a similar method by defining chemical groups based on histograms of the same elements as the SAM team. The choice of these four elements is a crucial point in the debate. It is one of the few areas of true consensus that they are of highly diagnostic value to archaeologists; however, what they reveal is still hotly debated.

One of the crucial differences between the SAM study and other interpretive schemes is that the latter used preselected objects according to typology (Waterbolk and Butler 1965) or region (Liversage 1994) for their classification, and they discussed them in greater detail. In doing so, they were not attempting to define a single set of compositional groups, rather to set a greater focus on the artifacts under study and characterize their nature. In the SAM study, the emphasis was more on the overview of the composition of metal objects and their compositional changes throughout the European continent, although typological studies were considered, 


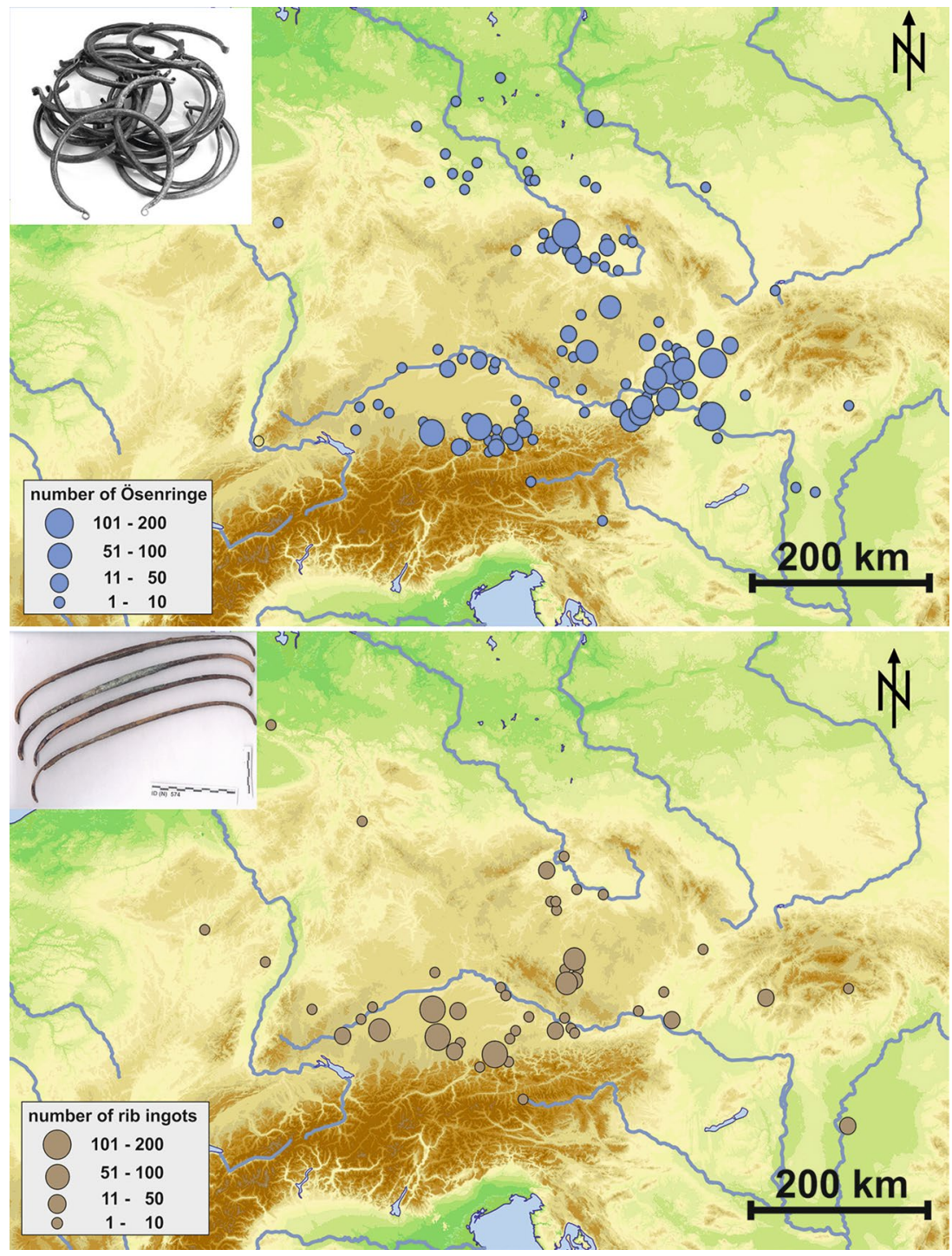

Fig. 3 Geographical distribution of two major types of ingots in the European Early Bronze Age: Ösenringe (loop or neck-rings, above) and Rippenbarren (rib ingots, below). The ingots were distinct in their morphology and in their trace element patterns (Ösenringe: $1-3 \% \mathrm{Sb}, 1-3 \% \mathrm{As}, 0.5-1 \% \mathrm{Ag},<0.1 \% \mathrm{Ni}$, $0.1-0.2 \% \mathrm{Bi}$; Rippenbarren: $0.5 \% \mathrm{Sb}, 0.5-3 \% \mathrm{As}, 0.3 \% \mathrm{Ag}, 0.5-3 \% \mathrm{Ni},<0.1 \% \mathrm{Bi}$ ) (Prepared by E. Pernicka)

too. Another indicated limitation of the SAM data is that this project dealt only with the European early metal ages up to the developed Early Bronze Age, and that the classification scheme they produced can be applied only to this region and time, even though scholars could follow their methodology for other case studies. Nonetheless, the SAM data have constantly been (re)used due to their reliability, and 
various research teams have either confirmed the mathematical procedures of the SAM team or expanded the method to address circulation of metals on a broader, Eurasian scale (e.g., Hodson 1969; Krause and Pernicka 1996).

The Oxford group (Bray 2016; Bray et al. 2015; Bray and Pollard 2012) takes a different stance by arguing that the SAM approach to chemical data clustering was based on what compositional array a single source and a consistent production technology were assumed to produce, with little regard on how this may be altered through subsequent melting, work, and use of the metal. We now understand that local differences in mines and production techniques produce variation in chemical elements in the produced metal (cf. Pernicka 2014). For example, from an archaeological perspective, the first objects produced from primary smelted metal need not be the "final products," as melting and mixing of objects can create further chemical structure that needs to be noted and understood, hence the biographical or characterization approach of the Oxford Group (cf. Bray 2016; Bray and Pollard 2012). They stress that specific patterns of human behavior can be inferred from meaningful variations in chemical composition of metal artifacts dictated by local (or regional) technological practices; this is where the SAM and Oxford Group meet.

These "localized" examples, such as local networks of exchange, re-melting, and a multiplicity of different techniques, have, for instance, been shown to take place across Early Bronze Age western Europe (Bray et al. 2015). One of the baselines is the argument that the individual skews and patterns in the arsenic distribution within an assemblage can be used to distinguish between primary and re-melted metal. An exemplary case study presents metal objects in Scotland as having been made from re-melting existing objects produced in Ireland, associated with the Late Chalcolithic-Early Bronze Age mine of Ross Island (Bray and Pollard 2012; cf. O'Brien 2004). Another example includes the investigation of a link between arsenical copper and copper containing arsenic and antimony in Early Bronze Age Iberia and exploring the history of individual units and assemblages of this metal (Bray et al. 2015). The observation that the concentration of arsenic in copper-alloy artifacts from this period drops with increasing distance from Iberia, with the overall distribution of arsenic skewing lower in France, suggests the movement of said metal from Iberia into France (Fig. 4). It is argued that this metal from Iberia was re-melted into local shapes in France in a process that resulted in the loss of arsenic as oxide (Bray et al. 2015). It is noteworthy that the SAM group identified different regional groups of arsenical copper on the same assemblages in southern Iberia and on the British Isles (termed groups E01A and E11A/B), whose spatial distributions appear mutually exclusive across the late third and early second millennium BC (Junghans et al. 1968, pp. 128-138, maps 44-47, 52-56) (Figs. 5 and 6). With the knowledge of their time and before the discovery of the copper mines on Ross Island (O'Brien 2004), SAM suggested that the copper group in Britain ultimately derived from central Europe, while today it is known that Ross Island was a major source of arsenical copper for the British Isles in the late Chalcolithic and the Early Bronze Age.

The Oxford Group maintains that the essence of SAM groups is static and that they do not reflect the nature of copper-alloy technology. Further, they argue that the best way to achieve Sangmeister's (1971) aims is to build explanatory models 


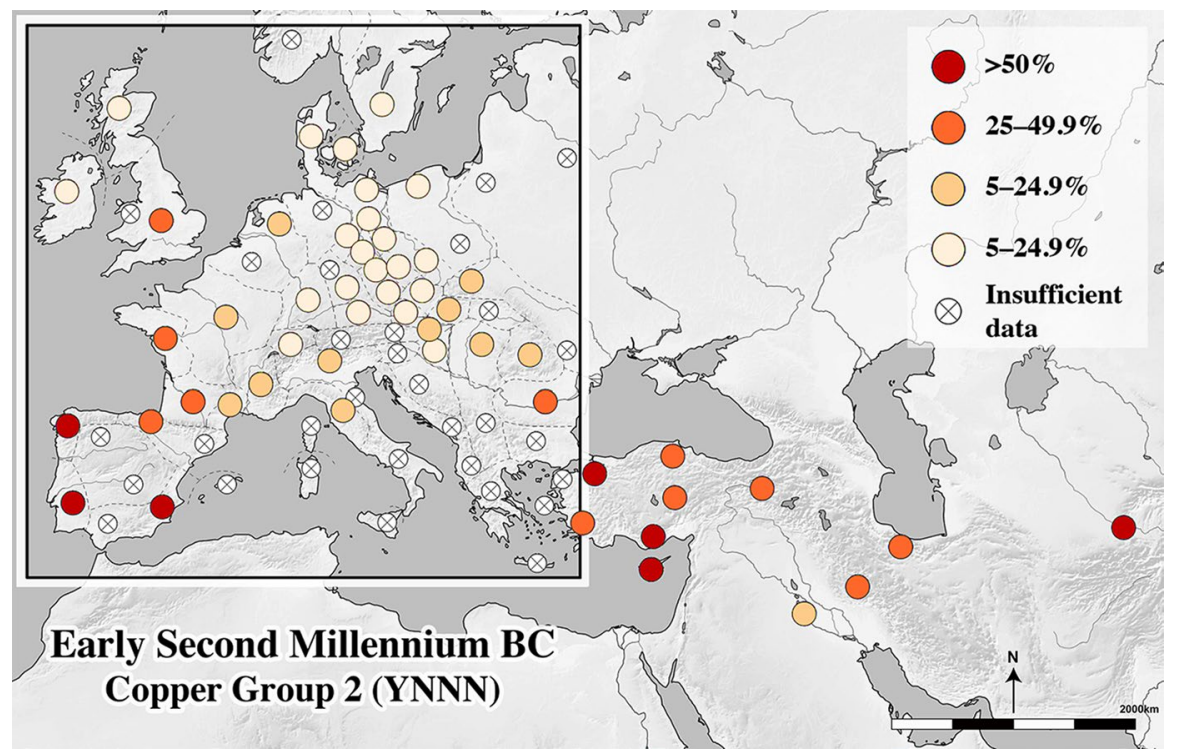

Fig. 4 Distribution of arsenical copper Group 2 as defined by Bray et al. (2015) (traces: As $>0.1 \%, \mathrm{Sb}$, $\mathrm{Ni}$, and $\mathrm{Ag}<0.1 \%$ ) in the European and western Asian Early Bronze Age. The inset map of Europe suggests an Atlantic coast transport of such metal into France and Britain and possibly another source coming into southeastern Europe via Anatolia. The larger map of western Asia is less complete but shows the distribution of this metal in the Near East with possible sources in Anatolia and Afghanistan (Adapted from Bray et al., p. 206, fig. 2; prepared by P. Bray and T. P. Leppard)

through characterization and comparison of the compositional analyses of relevant archaeological assemblages. This is developed via a multistep process that starts with 16 combination groups defined by presence or absence above a fixed threshold of four trace elements (As, $\mathrm{Sb}, \mathrm{Ag}$, and $\mathrm{Ni}$ ), set at $0.1 \mathrm{wt} \%$; the approach has been argued to present the full potential of the chemical space that these elements afford. By investigating where in this multidimensional space the various chemical compositions sit, the 16 combination groups are used as a characterization tool for any set of chemical data for copper alloys, which are then further interpreted along with the available archaeological and technological evidence (Bray et al. 2015).

The approach of Bray et al. (2015) to characterization, rather than provenance, is shown to be equally applicable to any set of analytical data for copper alloys, regardless of the region or time period (see Bray 2016; Bray and Pollard 2012 for Britain; Cuénod et al. 2015 for Iran; Hsu et al. 2016 for the Eurasian Steppe Iron Age; Perucchetti et al. 2015 for Italy; Pollard et al. 2015 for a Roman and Anglo Saxon study; Pollard et al. 2017a, b for China). Stretching from Atlantic Europe, through Russia and central Asia, to the Pacific Coast of China, the aim of the Oxford-based current research project (ERC-funded, Flow of Ancient Metals across Eurasia-FLAME, Table 1) is to synthesize published compositional data for third, second, and first millennium BC copper alloys based on the multistaged model discussed above. The described procedure stands in contrast to the approach of the SAM team and many other scholars, who searched for clustered groups in the multidimensional space 
Fig. 5 Geographical distribution of the (SAM) arsenical copper group E11A (top, "Irish" copper, traces: As $0.25-1.6 \%$, Sb $0.25-1.25 \%, \mathrm{Ag} 0.2-1.25 \%$, Ni 0-0.02\%) and (SAM) arsenical copper group E01A (bottom, "Iberian" copper, traces: As $0.13-2.5 \%$, Sb and $\mathrm{Bi}<0.01 \%, \mathrm{Ag}<0.1 \%, \mathrm{Ni}<0.015 \%$ ) in the late third millennium BC. The shading indicates positive (darker) or negative (lighter) deviation from an assumed equal distribution over 48 cultural regions in Europe outlined by the dashed lines. At the time of publication, the arsenical copper horizon in southeastern and central Europe was dated to the third millennium BC, while we now know from radiocarbon dates that it is actually a feature of the fourth millennium BC. Accordingly, this copper type is mainly found in the Iberian Peninsula in the third millennium BC and was compositionally distinguished from the "Irish" arsenical copper (From Junghans et al. 1968; prepared by E. Pernicka)

defined by five elements (As, $\mathrm{Sb}, \mathrm{Ni}, \mathrm{Ag}$, and $\mathrm{Bi}$ ) by using their whole concentration ranges. This approach, however, has since been met with criticism by Pernicka, who questions the geochemical and metallurgical justification of a fixed threshold of 0.1 wt $\%$ for trace elements.

Another aspect to consider in this debate is that grouping or "fingerprinting" of metal objects by chemical, isotopic, or typological means does not always necessarily need to focus on assigning them to broad provenance regions. As a first step, chemical or isotopic data may allow us to group objects that come from the same source or pool of metal, with further investigations to evaluate any proposed connections or origins (e.g., Junghans et al. 1960, 1968; Pernicka 1989; Pernicka et al. 1990; Pollard and Bray 2014). Likewise, by combining chemical data with detailed studies of style and manufacturing traits, it is possible to assign artifacts to individual workshops or artisans, or specific metal batches, under the broader level of "provenance regions," even when the geological source of raw materials may remain unknown (e.g., Leusch et al. 2015; Martinón-Torres et al. 2014; Martinón-Torres and Uribe-Villegas 2015). Microtypological analyses, aided by geometric morphometrics, can help identify objects that were cast in the same molds (e.g., Forel et al. 2009; Li et al. 2014; Monna et al. 2013). This information is useful for a more detailed characterization, not only of production organization or the make up of a hoard but also of mechanisms for trade and interaction across longer distances.

The measurement and comparison of elemental concentration data produced by different analytical laboratories represents yet another contested matter in our field. It essentially comes down to accuracy and precision of obtained measurements. Both terms are often used synonymously in colloquial speech; however, they have specific meaning in the context of scientific measurements. The accuracy of a measurement system shows how close the measurements of a quantity are to the true value. Low accuracy often is a result of a systematic error. The precision of a measurement system indicates the degree to which repeated measurements under unchanged conditions produce the same results. Low precision is a result of a reproducibility error. A measurement can therefore be accurate and precise, or neither, or accurate but not precise, or precise but not accurate.

The SAM data, for instance, are rather accurate but have low precision, with a standard deviation of $30 \%$ (Pernicka 1984). It is fortuitous that the elements Ni, $\mathrm{Ag}$, As, and Sb were reliably measured with the method used by the SAM project (atomic emission spectrometry, AES) and were, together with $\mathrm{Bi}$, the main elements used for the classification. These are still today, along with Au and possibly Co and 

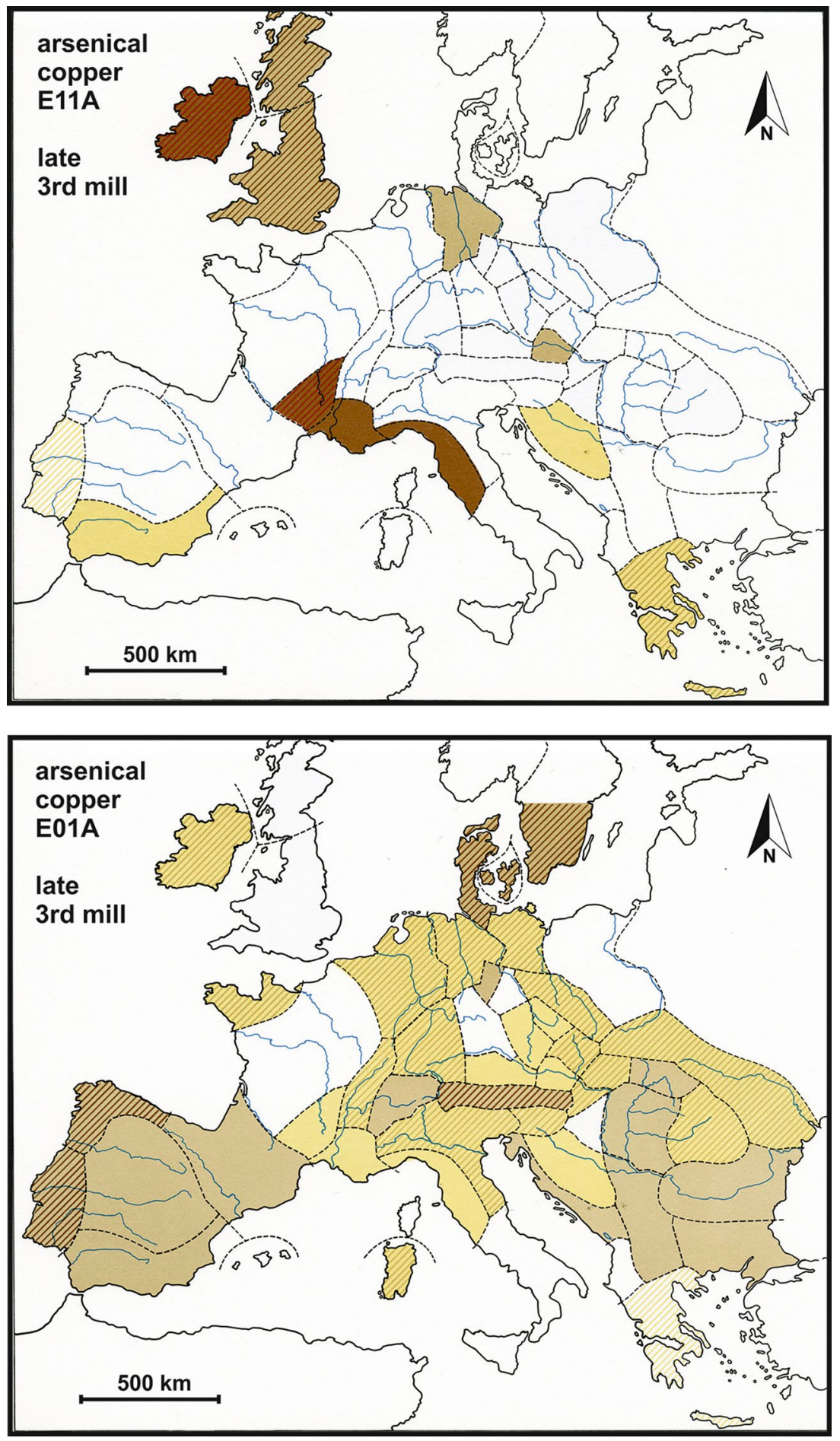
Fig. 6 Geographical distribution of the (SAM) arsenical copper group E11A (top, "Irish" copper) and (SAM) arsenical copper group E01A (bottom, "Iberian" copper) in the early second millennium BC with the same shading as in Fig. 5. This figure exhibits different approaches to interpreting legacy data of SAM to that of the Oxford Group (see Fig. 4). While the Oxford Group identified a single type of arsenical copper metal in the early second millennium BC Europe (called Copper Group 2), SAM distinguished different compositional groups showing development patterns of distribution of the "Irish" and "Iberian" arsenical copper groups in the late third and early second millennium BC Europe, leading to a different interpretation (From Junghans et al. 1968; prepared by E. Pernicka)

Se, the most useful trace elements that are now quantified more precisely with more sensitive analytical techniques (Pernicka 1999). However, for inter-laboratory comparison and for pooling data from different laboratories, it is essential to produce not only precise but also accurate data, which can be assured only by regular inter-laboratory comparisons. This highlights the urgent need for all data producers to keep reporting their analytical procedures in greater detail, including analyses of certified reference materials, to facilitate more reliable processing of large datasets.

\section{The Relationship of Source and Consumption Regions in the European Bronze Age}

Ore deposits are not evenly distributed but concentrated in certain geological formations and metallogenic provinces. They are exposed and accessible to early miners only in mountainous regions, typically far from the fertile lowlands that facilitated the formation of early complex societies. Following a century of archaeology focused on urban centers and cemeteries, much fieldwork in recent decades has been dedicated to the excavation and radiocarbon dating of prehistoric copper mines and smelting/melting sites. This has revealed many Bronze Age copper production centers throughout Europe, including mines in southwestern Ireland, Wales, England, Spain, France, Switzerland, Austria, Italy, Slovakia, Bulgaria, Romania, Greece, and Cyprus (see Fig. 1; Betancourt 2006; Boroffka and Heck 2006; Fontanals et al. 2017; Höppner et al. 2005; O’Brien 2015; Popov et al. 2011; Saez et al. 2003; StosGale 1989, 1998; Timberlake 2009; Weisgerber and Pernicka 1995 and references therein). Already it seems clear, however, that several large copper-mining areas were able at different times to establish dominant positions in metal supply in different regions (cf. O’Brien 2015, p. 34), with a major shift point observed around c. 1600/1500 BC (see below).

On the other hand, tin ore deposits are far fewer than copper deposits and are extremely unevenly distributed. The largest deposits are in western and central Europe-e.g., Cornwall, Brittany, the western Iberian Peninsula, and the Erzgebirge (Giumlia-Mair and Lo Schiavo 2003; McGeehan-Liritzis and Taylor 1987; Merideth 1998; Penhallurick 1986) with much smaller tin mineralizations found elsewhere (e.g., Ireland, southern France, Italy, and the Balkans) (see Fig. 1). However, there are currently no tin-mining sites in Europe that have been radiocarbon dated to the Bronze Age, in marked contrast to regions farther east (Boroffka et al. 2002; Garner 2014; Parzinger and Boroffka 2003; Stöllner et al. 2011; Yener et al. 2015). The archaeological evidence for potential sites of tin ore extraction relies on associated 

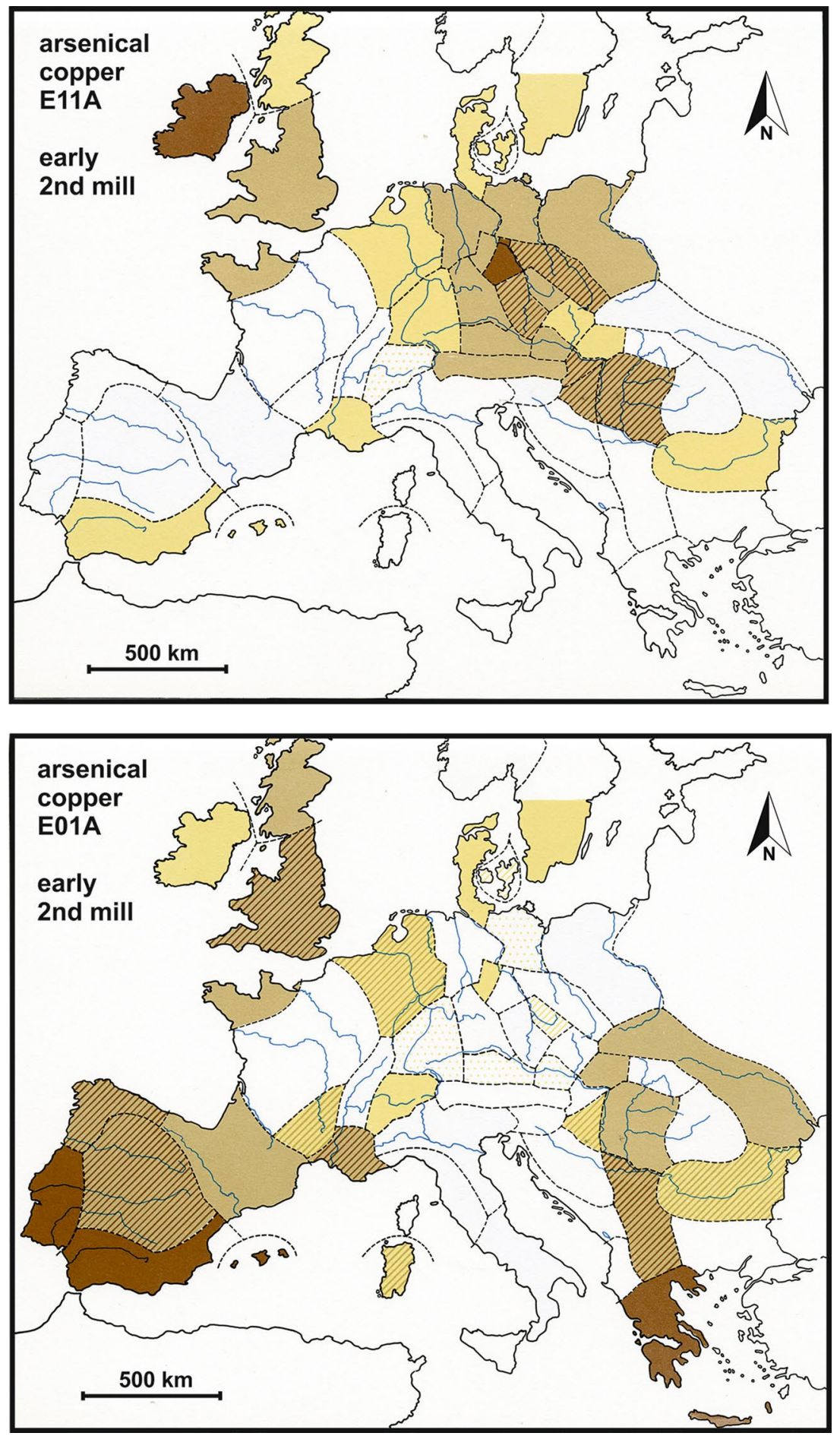
Bronze Age material culture or settlement activity, as at San Cristóbal de Logrosán in Spain or St. Renan, Finistère, in northwestern France (Mahé-le Carlier et al. 2001; Rodríguez et al. 2013). Bronze Age tin objects remain extremely rare and invariably comprise small beads, pendants, and other ornaments, such as those found at Tollense in northeastern Germany (Krüger et al. 2012). More substantial Bronze Age tin ingots are rarer still, whether found individually as at Sursee-Gammainseli in Switzerland (Nielsen 2014) or in larger groups, such as the 40 ingots found at the shipwreck site of Salcombe in southwestern England (Wang et al. 2016). Even though the relationships between tin sources and regions of tin consumption may, at the very least due to their geological distribution, have been of even greater significance than the relationships between copper sources and Bronze Age communities, it is the far more extensive copper-related evidence on which the current debates are founded.

Evidence for early metal production is mainly confined to smelting sites in metalliferous regions such as the Balkans, the Taurus, the Zagros Mountains, the Caucasus, and the Arabah Valley in the fifth/fourth millennium BC. Later, in the third and early second millennium $\mathrm{BC}$, metal production expanded to the Aegean, southern Iberia, the British Isles, the Alps, and the Slovakian Ore Mountains. However, most metal artifacts are not found in the primary production centers but in geographically related cultural centers. Further examples for strong regional patterning of the circulation of metal objects from the Chalcolithic to the Late Bronze Age are known in the Balkans (e.g., Dimitrov 2002; Gale et al. 2003; Pernicka et al. 1993, 1997; Radivojević and Grujić 2017), Iberia (e.g., Hunt-Ortiz 2003; Montero Ruiz et al. 2014; Murillo-Barroso et al. 2015; Stos-Gale 2001), the British Isles (Northover et al. 2001; Rohl 1996; Rohl and Needham 1998; Williams 2015), and wider central Europe (e.g., Artioli et al. 2014; Duberow et al. 2009; Frank and Pernicka 2012; Höppner et al. 2005; Niederschlag et al. 2003; Pernicka et al. 2016a, b; Schubert and Pernicka 2013).

The picture in Scandinavia is substantially different. Five recent, interrelated archaeometallurgy projects in the region (Table 1) provide more than 400 readings of chemical and lead isotopic data for bronzes dated from c. 2000 to c. 700 $\mathrm{BC}$, with the aim to advance knowledge on metal acquisition routes in this part of Europe (Ling et al. 2014; Vandkilde 2017a). There is currently no archaeological evidence of Bronze Age exploitation of copper ores in Scandinavia, despite the very rich archaeological record of bronze artifacts in the region. This absence of mining activity has been confirmed recently by lead isotope analysis, which demonstrated convincingly that southern Scandinavian bronzes could not have been made from southern Scandinavian copper ores (Ling et al. 2013). The clear implication is that, during the Scandinavian Bronze Age, all raw materials for making bronze artifacts were brought into the region from elsewhere, whether as copper or tin ingots, or as bronze artifacts, and then largely cast locally into new objects of regional typology (e.g., Kristiansen and Larsson 2005; Ling et al. 2014; Vandkilde 2014, 2017a). Current analytical results conclude that there are chronological variations in the supply of copper metal related to various ore types and geographical areas. The interpretation of new data suggests a new and much more complex picture of possible connections between Scandinavia and Europe in the Bronze Age than was previously 
anticipated. It is very clear that maritime traffic and networking were crucial in situating Scandinavia as a key region in Bronze Age Europe right from the onset (Ling et al. in press; Vandkilde 2017a).

The raw material of the earliest Scandinavian copper objects was coming from distant regions such as the eastern Alps, Slovakia, or the British Isles, which has been archaeologically and chemically confirmed (Klassen 2000, 2004; Klassen and Pernicka 1998; Ling et al. 2014; Pernicka et al. 2016a). The acquisition routes of copper for early (low) tin bronzes in Scandinavia (c. 2100-1700 BC) are now more clearly understood, as exemplified by the Pile hoard at the edge of the sea in southwestern Scania (Vandkilde 2017a). The emerging picture suggests that copper was mostly originating in the northeastern Alps (including Mitterberg and North Tyrol) and Slovakia, mediated by an Únĕtician interrelation between the Erzgebirge and the Baltic Sea, while a few artifacts are consistent with copper ores from the British Isles (cf. Vandkilde 2016) and ores from the Slovak Carpathians. During the first phase of the Middle Bronze Age (c. 1600-1500 BC), there was a change in copper supply; the reason for this is still being discussed (Ling et al. 2014).

While copper from the rising production of the Mitterberg mines reached consumers across temperate Europe (Pernicka et al. 2016a), Scandinavia seems to have relied on a string of copper sources, which apart from Mitterberg and the Slovak Carpathians, include the British Isles, the Italian Alps, and Iberia in the Late Bronze Age (Ling and Stos-Gale 2015; Pernicka et al. 2016a). It is hard to overestimate the significance of this in light of the substantial social transformations that were taking place in and beyond Scandinavia between 2100 and 1500 BC, with 1600 BC as a major threshold (e.g., Vandkilde 2014). During the Middle Bronze Age (c. 1500-1300/1200 BC), most of the Scandinavian artifacts are consistent with origin from copper deposits in the Italian Alps; a minority are consistent with British, Irish, and Iberian ores. Around 1200/1100 BC, in connection with the expansion of the Atlantic Bronze Age network, there was a visible shift in the sources of copper for the Scandinavian bronzes to southern Spain (Ling et al. 2014; Ling and Uhnér 2014).

Metal flow, however, is not necessarily unilateral from ore source to consumer site. In Mediterranean Europe, the expansion of long-distance metal flow during the Late Bronze Age is reflected in the wide distribution of copper oxhide ingots from Cyprus across the Mediterranean (Stos-Gale et al. 1997) and beyond (Primas and Pernicka 1998; S. Sabatini 2016). However, some tin bronze objects from Cyprus show consistency with copper deposits in the western Mediterranean, in Turkey, and possibly Iran (Gale and Stos-Gale 2012; Stos-Gale 2015), indicating the use of sources external to the island, even if the exact metal origins for these artifacts remain unknown.

The situation is therefore more complex than a simple model of production centers with a diffusion halo, with "foreign" metals also being found in various regions that otherwise could have supplied themselves. Early examples are Chalcolithic copper implements along the Danube to the Black Sea that can be related to, for example, the large copper deposit of Majdanpek (eastern Serbia) in the Balkans, and metal implements made from Aibunar copper (Bulgaria) (see Fig. 1) found in the vicinity of Majdanpek (Gale et al. 2003; Pernicka et al. 1997; Radivojević et al. 
2010). Similarly, most of the copper objects of the Nahal Mishmar hoard did not originate from the nearby copper deposits in the Arabah Valley; instead they may have derived from the Caucasus (Tadmor et al. 1995). Also, a number of copper and bronze artifacts from the Aegean (Troy II, Thermi, Poliochni, Kastri on the Cycladic island of Syros) show links to distant (i.e., beyond the eastern Mediterranean) and thus far unidentified ore deposits (Begemann et al. 1992; Pernicka et al. 1984, 1990; Stos-Gale 1992; Stos-Gale et al. 1984). The nature of these individual cases of "foreign" metal needs to be explored individually for each example, and any general assumptions on long-distance trade and exchange ought to be taken with caution.

In light of the available provenance data, it seems that throughout the entire Bronze Age in Europe different regions had distinctive patterns and therefore separate organizations of copper supply networks. A major change in these networks occurred possibly around 1600/1500 BC as evidenced in central Europe and the British Isles, for instance (Figs. 7 and 8), when a small number of sources witnessed an expansion in the scale of production and long-distance connections grew in size. Generally speaking, the largest copper deposits in operation before circa $1600 / 1500$ BC remained important afterwards, with the notable intensification of regional mining and exploitation activities. However, the characteristic lead isotope ratios of smaller exploitation activities (for example, on the Cycladic Islands and some occurrences in Bulgaria) disappeared from the later assemblages of analyzed bronzes. Lead isotope analyses indicate that the regions of Europe that were rich in copper mainly used metal from their local sources. The groups of analyzed bronze artifacts from the post-1600/1500 BC eastern Mediterranean, Alpine, Iberian, and Italian sites show distinctive lead isotope patterns characteristic of the local sources: e.g., Cyprus and Lavrion for the Aegean, southern Spain for Iberia, and Alpine copper for central Europe and Italy. Hence, and despite some metal objects crossing from one region into another, there was no noticeable widespread re-melting and mixing of metals between these regions in the mentioned period. This, however, does not exclude the possibility of metal being recast into new shapes or mixed with itself within these regions (see Rohl and Needham 1998 for the Great Orme ores), or that we may build models with various degrees of metal mixing across the observed regions or geographical boundaries; this matter certainly needs more future work and detailed elaboration.

\section{What Do We Know About Metal Circulation and Use in European Bronze Age Communities?}

Identifying what happened to a Bronze Age metal object between production and deposition is arguably a far greater challenge than establishing the geological provenance of the metal itself, yet such knowledge has the potential to reveal far more about the societies involved and to more comprehensively reflect past realities. This is primarily due to the nature of archaeological data. Aside from Bronze Age shipwreck sites, such as Salcombe and Langdon Bay off the coast of southern England (Needham et al. 2013; Wang et al. 2016) and Cape Gelidonya and Uluburun off the coast of southern Turkey (see Fig. 1) (Bass 1967; Hauptmann et al. 2002; Muhly 

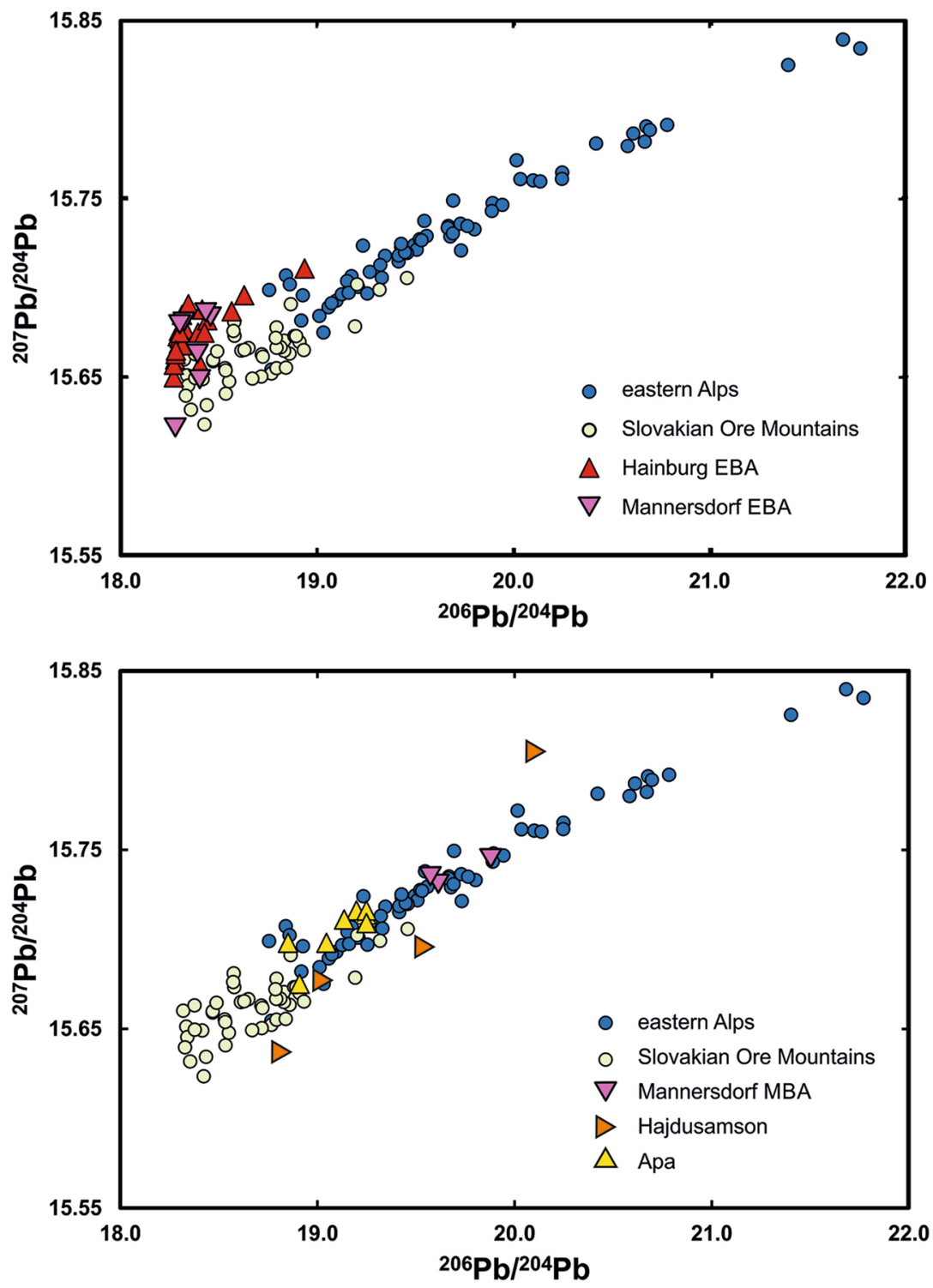

Fig. 7 A change in copper supply in pre-1600/1500 BC (above) and post-1600/1500 BC (below) central Europe. Above: Lead isotope analyses of an assemblage of Early Bronze Age bronze artifacts from the cemeteries of Hainburg an der Donau and Mannersdorf am Leithagebirge (Austria) are shown as consistent with Slovakian Ore Mountains. Below: Lead isotope analyses of an assemblage of Middle Bronze Age artifacts from the cemetery of Mannersdorf am Leithagebirge (Austria) and hoards in Apa (Romania) and Hajdusamson (Hungary) are shown as consistent with eastern Alpine copper sources (Data from Duberow et al. 2009; Pernicka et al. 2016b; prepared by E. Pernicka) 

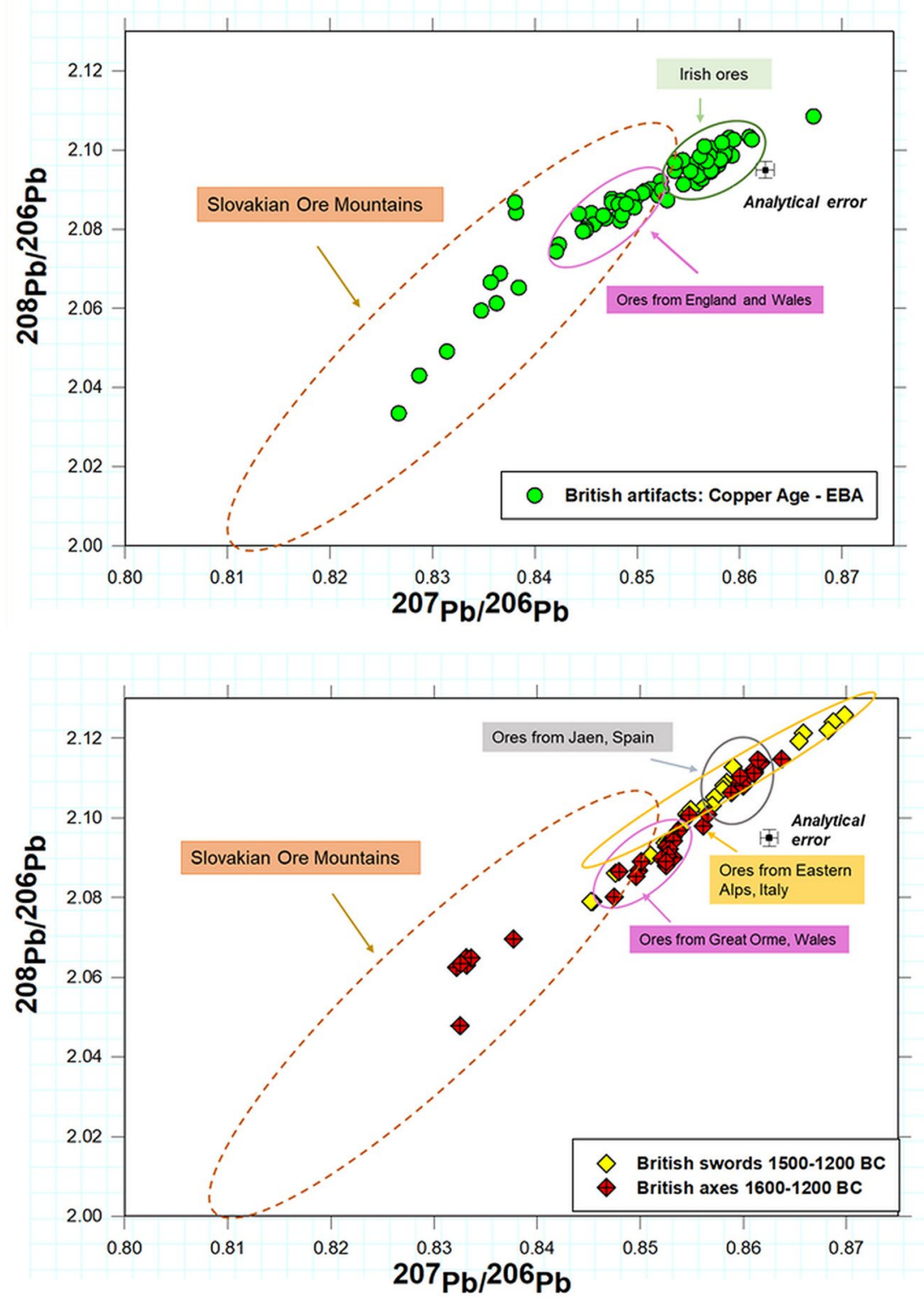

Fig. 8 Lead isotope analyses of British bronzes before and after circa 1600/1500 BC. Above: Bronze artifacts (92) from England, Wales, and Ireland analyzed for their lead isotope (LI) ratio and dated to before circa 1600/1500 BC (Copper Age-EBA IV) are shown as consistent in varied proportions with the ores from the British Isles and Slovak Ore Mountains. The dashed ellipse of Slovak Ore Mountains field shows only the approximate range of LI ratios for this deposit; the solid line ellipses indicate the groups of artifacts consistent with ores from Ireland, England, and Wales. Below: Bronze artifacts from England, Wales, and Ireland analyzed for their lead isotope (LI) ratio and dated to after circa 1600/1500 BC (MBA) are shown as consistent with ores from the Slovak Ore Mountains, Spain, Italy, and Wales. The solid line ellipses indicate the groups of artifacts consistent with ores from Jaen, eastern Alps, and Great Orme (Data from Rohl and Needham 1998; prepared by Z. Stos-Gale) 
et al. 1977; Pulak 1998, 2010), it is rare that Bronze Age metal is discovered in the act of movement (see Lucas-Pellicer and Gomez-Ramos 1993) rather than in its (un) intended resting place.

Secondly, the intentional, and primarily votive, nature of European Bronze Age metalwork deposition means that the vast majority of the recovered metal objects are not likely to be straightforwardly representative of the far broader range of metalwork in circulation and use (e.g., Bradley 1998, 2017; Fontijn 2002; Hansen 2013; Yates and Bradley 2010). Beyond Europe, the striking absence of metal objects in the archaeological record relative to the substantial presence of metal in textual sources relating to the Bronze Age metals trade from Anatolia to Afghanistanmost recently at Kanesh, Turkey (Larsen 2015)_provides a cautionary perspective. One may suggest that the urban and state societies in those areas applied a different value system to metal that led to fewer depositional practices and/or far greater rates of re-melting and recycling in comparison to Europe. We address some sources of metal loss through analytical and experimental evidence in greater detail below.

Thirdly, difficulties arise from the ability of Bronze Age metalsmiths to remelt, recycle, and resharpen any metal object, thus altering its form, composition, and any evidence of use. Clearly, the metalsmiths at the time of these events must have learned how different treatments affected mechanical properties of the desired object and acted accordingly. Taking two primary prehistoric copper alloys as an example (copper arsenic and copper tin), different ratios of arsenic and tin, respectively, to copper in the binary alloys dictate tensile strength and ductility (Lechtman 1996; Maréchal 1958; Northover 1989); these differences likely were noted by Bronze Age metalsmiths. Thus, depending on the desired function of a new object, as well as its aesthetic appeal (cf. Mödlinger et al. 2017; Radivojević et al. 2017), the production process from raw or recycled metal must have required different levels of control.

Fourthly, the development of use-wear analyses on Bronze Age objects is starting to see more widespread application as are better recording systems, fewer untested assumptions, and a greater awareness of the complexities of interpretations (see Dolfini and Crellin 2016; Gutiérrez-Sáez and Martín-Lerma 2015; Horn 2013; Kristiansen 1978, 1984, 2002; Kristiansen and Suchowska-Ducke 2015; Kuijpers 2017, 2018; Molloy 2008, 2009, 2010; Molloy et al. 2016; Roberts and Ottaway 2003; Uckelmann and Mödlinger 2011). What is required is an approach to analyzing and understanding Bronze Age metal circulation and use that can evaluate and further advance the established models and interpretations based on morphologies, typologies, and distributions of Bronze Age copper and bronze objects throughout Europe. The potential for such scholarship is substantial, as exemplified over the last 50 years by the 187 volumes of the excellent Prähistorische Bronzefunde series (see review by Jockenhövel 2016).

Importantly, the current use of chemical composition data for the characterization of ancient metals in space and time via statistical analyses builds on earlier projects, particularly the work of Coghlan and Case (1957), Waterbolk and Butler (1965), the SAM group (Junghans et al. 1960, 1968, 1974), Liversage (1994), Northover (1980, 1982), and Chernykh (1992). Other classification systems use, for instance, methods based on the spread of elemental patterns (Needham 2002; Northover 1980), complex networks science (Radivojević and Grujić 2017), or the application of GIS 
techniques (e.g., Perucchetti et al. 2015). Similarly, using GIS coupled with multivariate data modeling of metal compositions as well as information on settlements, hoarding, and metalwork, Rassmann (2011) tracked aspects of metal production, circulation, and consumption in the Early Bronze Age of non-Mediterranean Europe. These studies highlight the great potential of such large datasets. How to recognize recycling and determine when and the degree to which it occurred is a promising research area.

The impact of recasting and mixing on the chemical character of ancient copper alloys is actively debated. The notion that recycling would cause some chemical alteration of the metal has been widely agreed; however, the question that remains is how to estimate the amount of metal lost during re-melting and the frequency of recycling. Had metal recycling been a predominant practice in the European Bronze Age, then, as Pernicka argues, the original Early Bronze Age metal artifacts would not have survived a couple of generations, if we take into account an estimated loss of 5\% during metal re-melting. This calculation has been demonstrated by Patterson (1972) for silver metal, which disappears with a half-life of 23 years at an annual loss rate of only $3 \%$. Furthermore, if large-scale metal mixing were a general practice in the Bronze Age, scholars would not have been able to observe large compositional differences of prehistoric copper objects in space and time, since constant mixing would have homogenized the metal stock (Fig. 9). This conforms with the prevailing trend of low-impurity copper in the later Bronze Age metal types in the SAM study (cf. Junghans et al. 1968, vol. 2), which can be explained by the increased use of chalcopyrite ores across time in Bronze Age Europe rather than large-scale mixing.

We need, however, to acknowledge the fine detail of the term recycling, which covers a range of interlinked behaviors, some of which, such as re-melting and recasting a whole object into a new shape, would not obscure an overall pattern of the chemical elements. We have already discussed the movement of metal from a

Fig. 9 Recycling or mixing of two or more components that can be present in individual objects or groups of objects with similar composition necessarily leads to homogenization as shown in this hypothetical diagram of two chemical elements and five metal objects (the dots) that are mixed. If more than two metal objects are mixed, it is practically impossible to reconstruct the composition of the end members (Prepared by E. Pernicka)

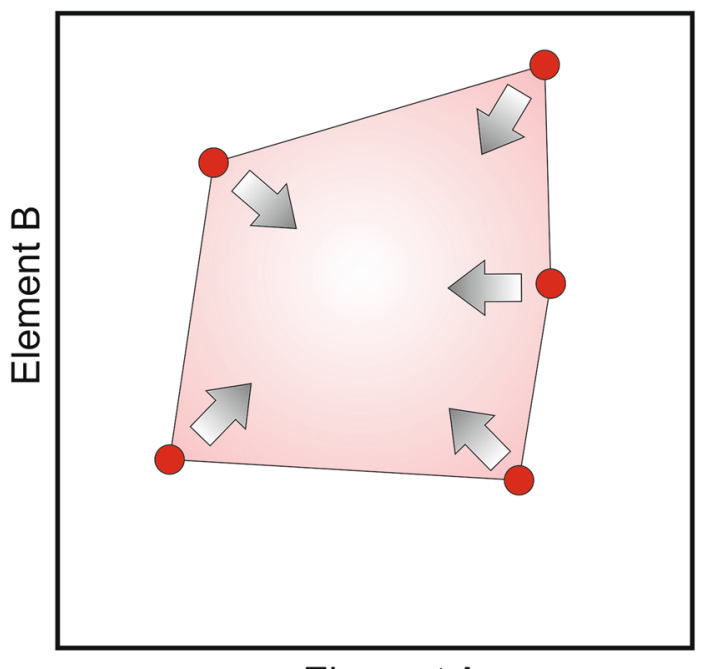

Element A 
range of sources into Scandinavia, which are then recast into locally appropriate shapes. This modification and manipulation of the metal stock is socially significant and central to understanding the movement and conception of metal. For example, the life history of a quotidian and utilitarian object is unlikely to be similar to the Nebra Sky Disc, mentioned above. The monolithic term "recycling" hence hides the numerous ways that copper alloys can be manipulated; more often than not, it leads scholars into contentious debates at cross-purposes, as they do not share the same terminology.

The loss of arsenic through re-melting of metal is yet another point that has been discussed at length in the past few decades (e.g., Northover 1988). The idea of tracing recycling patterns through the depletion of arsenic in arsenical bronzes was voiced in a recent study of the Early Bronze Age in Britain mentioned above (e.g., Bray and Pollard 2012). McKerrell and Tylecote (1972, p. 211, table 3) began to explore the mechanisms under which this loss occurs, by showing that arsenic will be lost (as arsenious oxide) during re-melting under oxidizing conditions, particularly when present at higher concentrations in an alloy, but not below c. $2 \mathrm{wt} \%$. In order to understand the principles behind the arsenic loss, it is important to note that arsenic is not lost directly out of molten copper; it oxidizes, and then that oxide is rapidly lost. McKerrell and Tylecote (1972) demonstrated that little chemical change occurs during melting in fully reducing conditions, which explains why elements from copper ore partition into smelted copper (e.g., Tylecote et al. 1977 and literature therein). The behavior of arsenic and arsenious oxide under oxidizing conditions does not happen in a simple linear pattern, and the nature of this relationship has recently undergone extensive theoretical modeling. Sabatini (2015) confirmed through thermodynamic modeling that significant losses of arsenic only come with the introduction of oxygen to the system; even in the presence of low amounts of oxygen, such as might occur in a reducing environment controlled by charcoal in the past, the evaporation of arsenious oxide is predominantly responsible for arsenic losses. He further confirmed the earlier observation that it becomes increasingly challenging to remove arsenic from copper, the lower the concentrations of the former are, even at moderately oxidizing conditions. The reason for this is the self-inhibiting effect of the strong affinity of arsenic to molten copper that leads to a depletion of arsenic at the surface of the melt on oxidation. The arsenic becomes less available for oxidation on the surface, and its loss from the copper melt decreases (B. Sabatini 2015, p. 2990). In addition, Meeks (1993), Budd (1991), and most recently Mödlinger and Sabatini (2016) demonstrate the extreme inverse segregation that arsenic undergoes in copper during solidification. This causes profound surface enrichment, which makes arsenic vulnerable to both oxidative losses from the surface and removal by mechanical abrasion. Beyond these effects we also need to consider the potential for mixing to obscure chemical signals.

The overall trend of arsenic's vulnerability during metallurgical processes is extremely useful for identifying the direction and nature of (s)melting operations. While experiments demonstrate what happens to arsenic loss in a variety of redox conditions, the next challenge is to reconstruct these conditions for past re-melting processes. There is a general consensus today that ancient re-melting of copper alloys took place in crucibles covered with burning charcoal, and that within such a 
pyrometallurgical design the redox conditions were on average at least mildly reducing. Yet, local conditions would have varied and included more highly oxidizing areas (Müller et al. 2004), e.g., directly in front of the blow pipe nozzle, where rapid loss of arsenic might have happened. Overall, while oxidative losses of arsenic may have occurred, the scale of loss remains unclear. In sum, the major disagreement among scholars rests on the matter of when and to what extent rather than whether metal recycling occurred in the Bronze Age and how to identify it.

The analytical evidence for metal mixing in the Bronze Age has recently been highlighted in a study of 1200 metal objects from southern Germany and Austria dating from the Early to the Late Bronze Age, including whole and fragmented implements and ingots. The main difference between these two types of objects was in the trace element signature, where a small number stood out with a mixed trace element signature of fahlore and chalcopyrite copper (Pernicka et al. 2016a). The term fahlore copper is reserved for objects made of copper smelted from ores dominated by fahlore minerals, commonly containing arsenic and antimony in the percent range, while chalcopyrite copper is usually recognized by low-impurity levels and, especially in the eastern Alps, by equal concentrations of arsenic and nickel. Both metal types were produced from the Early Bronze Age onward in southern Germany and Austria. In analyses of metal artifacts from the Early Bronze Age, the fahlore copper predominated (Fig. 10), before chalcopyrite copper replaced it by the end of this period. If recycling had been dominant, then we should have seen an increasingly diluted fahlore copper with arsenic and antimony concentrations fading out with time (i.e., in the Middle Bronze Age); however, this has not been observed (Fig. 10). It is unclear why the preference for fahlore copper reemerged in the Late Bronze Age, although it is possible that either mixing and/or recycling became a popular/necessary activity only in this period, or that the use of fahlore copper was a reaction to a potential tin shortage (or limited access to), since arsenic and antimony from fahlore would have had similar effects on the physical properties of copper metal (for these properties, see Lechtman 1996 and literature therein). An example from the same region (eastern Alps) displayed in Fig. 11 shows the end members (fahlore copper and chalcopyrite-type copper) being mixed in Late Bronze Age metal artifacts, but comparably less so in contemporary bun ingots from this region.

With experiments providing useful baselines to model what may happen to the composition of metals during smelting, alloying, remelting, recycling, and smithing, it is important that the parameters for those experiments are based on actual parameters determined archaeologically. The temperature and atmosphere of metallurgical processes are best inferred from the study of production debris such as slag, crucibles, tuyères, furnaces, and so on (e.g., Craddock 1995; Hauptmann 2014; Killick 2014; Martinón-Torres and Rehren 2014; Rehren 2003; Tylecote 1976; Tylecote and Boydell 1978). The study of European Copper and Bronze Age metal production shows a wide variety of systems operating at different temperatures and redox environments, which would affect metal composition in various ways (e.g., Bourgarit 2007; Höppner et al. 2005; 2007; Müller et al. 2004; Murillo-Barroso et al. 2017; Radivojević and Rehren 2016; Rovira 2004). If we focus on bronze specifically, there is widespread archaeological evidence, primarily from the Iberian Peninsula, for the production of the alloy by the co-smelting 


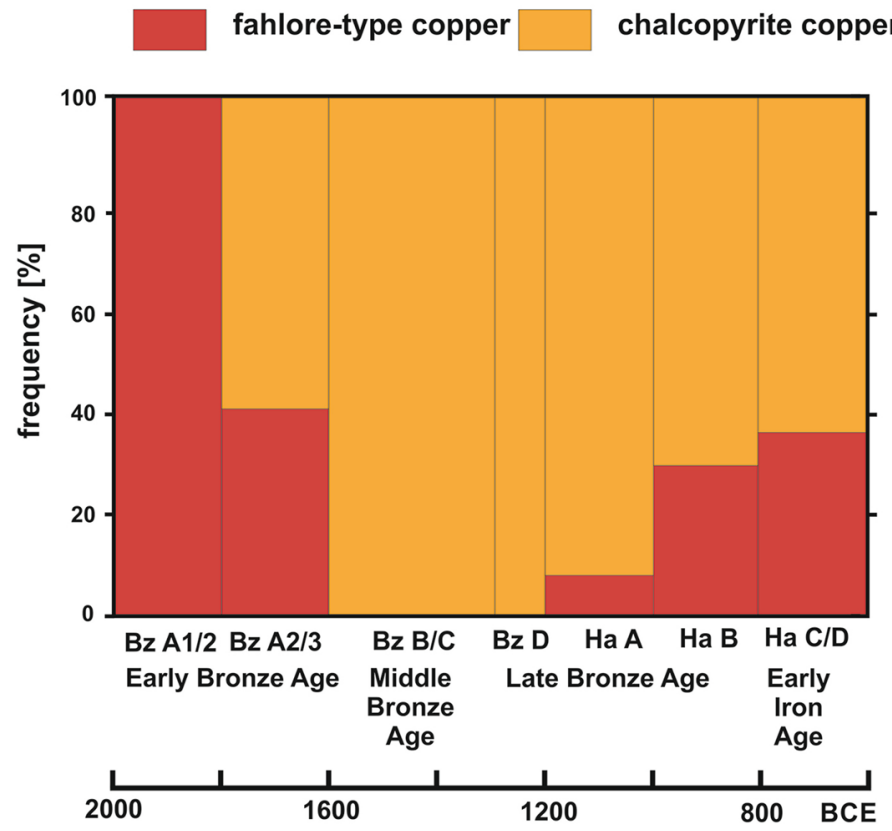

Fig. 10 Abundances of copper with fahlore and chalcopyrite signatures produced in the eastern Alps from the beginning of the Bronze Age into the Hallstatt period based on the compositions of approximately 1200 prehistoric metal artifacts from Tyrol, Salzburg, and southern Bavaria. Had recycling been regularly practiced, we would have seen an increasingly diluted fahlore-type copper with arsenic and antimony concentrations continuing into the Middle Bronze Age phase. Instead, there were abrupt changes over time, with fahlore-type copper reappearing in the Late Bronze Age (Data from Pernicka et al. 2016a; prepared by E. Pernicka)

of copper and tin minerals, or the cementation of metallic copper with cassiterite in crucibles in rather wasteful reactions (i.e., with much tin lost in the slag), and with highly variable temperature and redox conditions within individual crucibles (e.g., Farci et al. 2017; Figueiredo et al. 2010; Rademakers and Rehren 2016; Rovira 2007; Valério et al. 2014). Such conditions are difficult to replicate in a laboratory or model by computing, but the archaeological evidence should at least caution against undue generalizations. These problems may challenge inferences about the change in metal composition during smelting and remelting, but they also call for more experimentation on different alloying practices, including both primary production and subsequent remelting. It is thus imperative that, as far as possible, the evidence from extractive metallurgy is brought into the debates on provenance and recycling and is considered in the building of inferences on patterns of metal production.

We also should be cautious with chronologies (cf. Pollard et al. 2014) and avoid sweeping, generalizing statements about "metal circulation in the Bronze Age." According to the existing body of both LI and trace element data, there is no evidence for a large continental "melting pot" that would have compositionally 


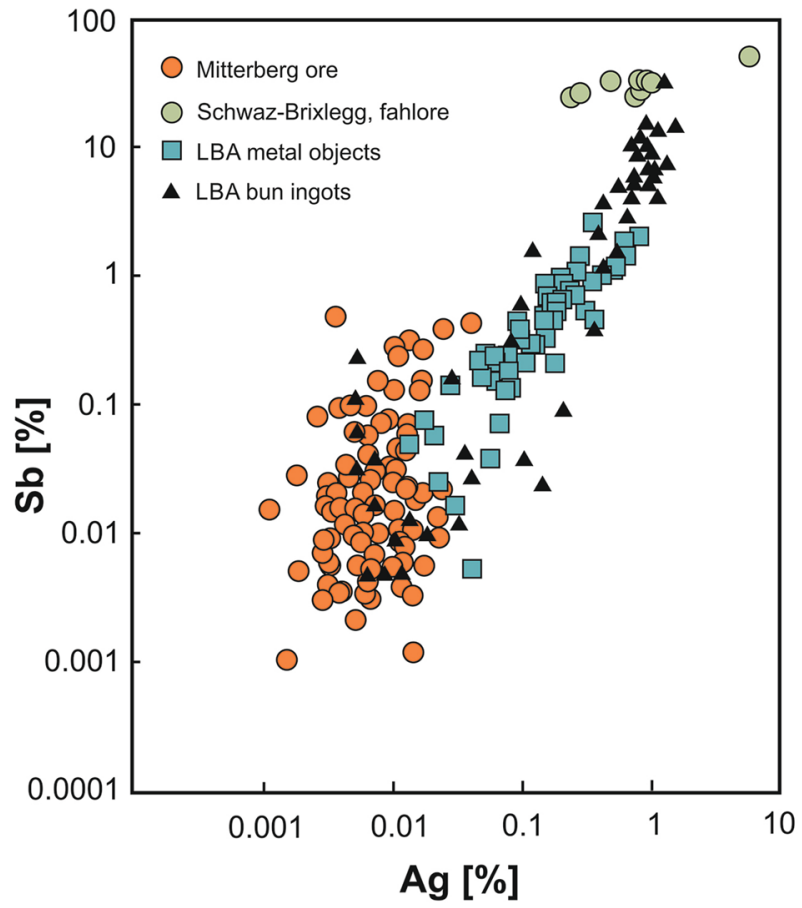

Fig. 11 An example of mixing of fahlore-type copper metal from Schwaz-Brixlegg and low-impurity copper ore of the Mitterberg region, both in the eastern Alps. Most Late Bronze Age bun ingots from the region consist either of fahlore-type metal or chalcopyrite copper with a few in between, suggesting mixed copper. Most Late Bronze Age objects from the same region are scattered between the two extreme compositions, with Late Bronze Age bun ingots produced from Schwaz-Brixlegg fahlore and from Mitterberg chalcopyrite ore. This could be due to recycling or intentional mixing of the two types of metals to produce objects (Data from Pernicka et al. 2016a; prepared by E. Pernicka)

homogenized the metal used for European bronze making and trading prior to circa 1600/1500 BC. We have highlighted the likely scenario that different regions have distinctive patterns and therefore most likely separate copper supply networks throughout most of the Bronze Age. Furthermore, we reiterate that the available analytical evidence speaks of a major change that occurred around $1600 / 1500 \mathrm{BC}$, with a change in the scale of production for a select number of sources and an expansion of long-distance connections.

Analyzing the circulation and use of metals in the European Bronze Age is therefore a complex task that requires knowledge of metal technology, working, and usage at ideal equilibrium conditions as well as real (i.e., nonequilibrium) conditions. Similarly, an understanding of postdepositional, postexcavation, and analytical treatments to which objects of study have been exposed is essential. Needless to say, researchers should focus their efforts on artifacts sourced in known archaeological sites and be wary of the ethical and research risks of trying to derive archaeological information from unprovenanced antiquities (e.g., Pernicka and Wunderlich 2017). Bearing in mind 
and addressing these challenges will eventually enable us to better understand the relationships between European Bronze Age metallurgy and societies.

\section{European Bronze Age Metals and Societies}

We address the theoretical and methodological challenges here in approaching the analysis of the value of metal to European Bronze Age societies primarily, and most productively, from the perspective of copper-mining economies, metal trade and exchange, and the creation and societal impact of bronze hoards.

\section{Copper-Mining Economies}

The occurrence of early mining and metal production on anything more than a very small scale implies production for the purposes of exchange and raises questions about what benefits were being gained by the producers from their involvement in such production, which is both arduous and complex. This apparent contradiction of costs and benefits was addressed directly by Shennan (1999) on Alpine copper using Ricardo's "law of comparative advantage" in a paper that continues to resonate with current approaches. Small autonomous Alpine communities produced copper in the early second millennium $\mathrm{BC}$ from sources located on the periphery of the main settlement area where the consumers of the copper lived. The essence of copper production was that it was produced for exchange; it would have taken very little to satisfy the needs of the communities themselves. The reason why communities immediately outside the mining region did not engage in primary copper smelting may seem obvious: the ore was not locally available. Yet this did not prevent primary smelting from being carried out at some distance from ore sources in other times and places. It may be that such communities could get higher returns on their labor by engaging in other activities, such as keeping cattle and obtaining their copper by means of exchange, but certainly they too must have been using some of their production for exchange purposes. Mountaindwelling communities would have gained less return on agricultural activities because of inferior growing conditions.

This example shows that a further understanding of the economic organization of mining requires a regional and interregional perspective recognizing that we are not just dealing with local systems; quantitative experimental studies, on the basis of the archaeological evidence, of the labor productivity of different ores and different production procedures, from mine to metal, and indeed of other resources such as salt; and isotope-based characterization studies, not just of metals but also of animal remains, to establish the movement of resources, the scale and intensity of regional production systems, and specific patterns of specialization (e.g., Stöllner 2003).

\section{Metal Trade and Exchange}

The role of metals in Bronze Age trade and exchange throughout Europe, and particularly as potential pre-monetary currency, remains a key point of debate (Harding 
2013; Kristiansen 2017). There are complexities in the evidence that go beyond the identification of weight systems (cf. Lo Schiavo 2006; Pare 1999, 2013; Rahmstorf 2010, 2011) or the classification and distribution of ingot forms (e.g., GomezRamos 1993; Le Carlier et al. 2014) and defy simple explanations. For example, the role of ingots as a potential pre-monetary currency is complicated by the evidence for Early Bronze Age ingot metal such as the Ösenring copper, which has a distinctively different composition from other bronze objects, suggesting that the metal tied up in them was only exceptionally converted into items of everyday use. In contrast, it appears that Bronze Age rib ingots were the mediators of some of the new stocks of copper that began to spread at $1700 \mathrm{BC}$ and had a literal breakthrough circa 1600 BC (cf. Lenerz-de Wilde 1995, 2002) (see Fig. 3). In reference to the latter, over roughly one millennium, the prolific Mitterberg mines in the Austrian Alps (c. 1700-700 BC) produced around 20,000 metric tons of copper (Pernicka et al. 2016a, pp. 28, table 2); this would have produced around 200,000,000 rib ingots of around $100 \mathrm{~g}$ each. Thus far some 1500 extant examples of rib ingots were investigated by Junghans et al. (1968), and most recently approximately 600 more (Seewald 2017), most weighing 90-120 g. The number of analyzed items speaks of the fragmentary nature of our knowledge of metallurgy at the time.

The existence of large hoards of broken metal objects, perhaps more appropriately termed "hack-bronze," which became increasingly common in Europe from the mid-second millennium BC onward, presents an additional level of complexity (Armada and Martinón-Torres 2016; Dietrich 2014; Wiseman 2018). In the hoard record, both categories_-standardized ingots and hack-bronze-occur largely in mutual exclusion, which seems to support the notion that they represent two fundamentally different systems of pre-monetary currencies, one based on units with fixed denomination, the other freely scalable within the constraints of the relevant weight system (Brandherm 2004). While the metallurgical composition of hack-bronze normally corresponds to a cross section of the metal in circulation within its ambit, this does not necessarily hold true of pre-monetary currencies based on standardized units with fixed denomination, whose issue requires much tighter social control and consequently may draw on a much more specific stock of raw material.

The increasing flood of new data relating to Bronze Age Europe, as well as our abilities to analyze them, has significantly enhanced potential estimations and calculations relating to absolute numbers of settlements, materials, or people (e.g., Holst et al. 2013). Thus, if we combine data from well-excavated settlements with exceptional preservation, such as Must Farm in England (see Table 1) or the lakeshore settlements of Switzerland (Menotti 2001, 2004), where we get a glimpse of the everyday use of bronze tools and objects, with statistics from larger regions, we arrive at figures with a rather high degree of probability. In Must Farm (see Fig. 1), every house had a bronze assemblage that included seven axes, two spears, two sickles, two chisels/gouges, and a razor (Wiseman 2018, p. 46); similar assemblages have been found in Bronze Age Swiss lakeshore settlements. We may thus assume that each farm during the Bronze Age had a set of tools with at least two axes and two sickles. Similarly, we may use well-surveyed/excavated regions, such as Thy in northwestern Jutland, Denmark, as a parameter for calculating the density of farmhouses in the wider settled regions. With many farmsteads and barrows in the richest 
areas of Thy, overall household density was about 1/square $\mathrm{km}$ and locally higher (Bech and Mikkelsen 1999; Earle and Kolb 2010). With a household consisting of ten extended family members and perhaps five slaves, a population density of 15 people per square km seems plausible.

We can now start combining estimates for the number of farms with estimates for the number of bronze tools in use and ask how large were stocks of bronze in Denmark during the Bronze Age and how fast was the rate of replacement? For the period between 1500 and $1100 \mathrm{BC}$, if we use a conservative estimate based on the distribution of circa 50,000 Early Bronze Age barrows (Holst et al. 2013), combined with our knowledge of farm densities, we can assume that half of Denmark $(22,000$ square $\mathrm{km}$ ) was settled at one farm per square $\mathrm{km}$ and each farm had at least two working axes of $500 \mathrm{~g}$, which were the most important tool for daily purposes. In this scenario, the 22,000 farms required a stock of 22 metric tons of bronze. Since axes would have been worn by daily use and sharpening, they were conservatively reduced annually by $5 \%$ (25 g/farm), which suggests a replacement rate for Denmark Bronze Age metal of about 1 metric ton per year. One metric ton of metal (or $1000 \mathrm{~kg}$ ) would equal around 30-35 oxhide ingots (each around $30 \mathrm{~kg}$ ).

We can then add to this a considerable consumption of bronze sickles, weapons, and ornaments needed for use, replacements, and burial and hoard consumption; the figure for the deposition of swords alone around $1300 \mathrm{BC}$ (Period II-III of the Nordic Bronze Age) ranges between 10,000 and 20,000 (Bunnefeld and Schwenzer 2011; Kristiansen and Suchowska-Ducke 2015). From these rough extrapolations, the annual imports of metal in the region must have been very high, at least from 1600 BC onward and would have required regular and well-organized trade expeditions. Such regular long-distance movement was clearly feasible and probably happened regularly, as shown by the annual travel of the Egtved woman between south/ central Germany and Jutland (Frei et al. 2015, 2017).

In addition to extensive metal imports, woolen textiles, whether finished or semifinished, would have been imported. In northern Europe at this time, apparently no wool industry existed; $80 \%$ of the analyzed textiles from there have nonlocal origins (cf. Frei et al. 2015). Again, such imports must have been substantial and costly. Considering the estimate of Denmark's population during the period after $1500 \mathrm{BC}$ (c. 220,000-300,000 people), thousands of pieces of cloth must have been imported annually from the south. The picture of an organized, regular, long-distance commodity trade emerges from these figures.

When evaluating models of exchange, we need to consider not only the extent to which people and ideas moved with metals but also the other commodities that may have been exchanged for ores, ingots, or finished metal artifacts. Livestock was mentioned above; amber is another important good. Baltic amber is often cited as a key material that moved south while metals moved north, and it has been used to explain the purported presence of Iberian metals in the Scandinavian Bronze Age from circa 1200 BC (Ling and Uhnér 2014). However, when viewed from the Iberian perspective, the evidence for the contemporary acquisition and consumption of Baltic amber is less clear-cut. For instance, before c. 1000 BC, amber finds in Iberia are clustered in Catalonia, far from the main Iberian copper sources or any of the routes the metal would have to take to get to Scandinavia. The amber is also invariably non-Baltic 
and deposited in collective burials. After $1000 \mathrm{BC}$, there is more evidence for Baltic amber finds, when they are found in individual burials and in settlements (MurilloBarroso and Martinón-Torres 2012). However, the presence of amber is overwhelmingly linked to an orientalizing or "precolonization" context tied into the nexus of intensifying Mediterranean contacts at that time. As Vilaça (2008, p. 376) argued, it seems most likely that the Baltic amber came to the central Mediterranean and from there made its way to the west with other commodities through Phoenico-CypriotSardinian connections. This is not to deny the role or likely importance of Baltic amber as a valuable material in Bronze Age trade systems, including exchanges involving metal, but to highlight the difficulties of establishing direct exchange relationships and the ongoing need for models to be proposed and evaluated.

\section{Creation and Societal Impact of Bronze Hoards}

Bronze objects were frequently hoarded either as single depositions or as several objects in one ensemble in a practice that, once established prior to $2000 \mathrm{BC}$, was maintained for the whole duration of the Bronze Age throughout Europe. This contrasts with the Bronze Age in the Near East where metal largely remained in circulation or is only occasionally found in religious structures (Gernez 2013; Philip 1988), or the Bronze Age in East Asia where metal was invariably, but not exclusively, deposited in funerary contexts; these differences deserve further investigation (Bagley 2014; Chen et al. 2016; L. Liu and Chen 2012; Wengrow 2011). In Europe, sometimes the hoarded objects may have been meant for retrieval on a later occasion, but in most cases they were clearly not. Albeit embedded in many different societies and not equally frequent throughout the macroregion, the hoarding practice of the Bronze Age entails a shared logic. This may be due to the interconnectivity established with bronzization at circa 2000 BC (sensu Vandkilde 2016), since hoarding did not previously exist on such a large and expanding scale. Having said this, the practice of hoarding is also embedded in local culture and developments linked to increasing social inequality and the accumulation of wealth.

Bronze hoarding reveals at least two-sometimes entangled-motivations, namely, curation of direct benefit for the living and sacrifice to gods or ancestors of indirect benefit for the living (Hansen 2013; Osborne 2004; Wengrow 2011). The existence of these two perspectives is evident throughout the scholarship surrounding Bronze Age hoarding practice (Vandkilde 2017b). One instance is the debate surrounding the intentional fragmentation of deposited bronze objects. This practice has been taken by some scholars as an indicator of commodification (cf. Bradley 1985), while others have interpreted it as a sign of nonutilitarian ritual decommissioning (cf. Boulud and Mélin 2009; Nebelsick 2000). Yet, hoards also may gather objects with disparate or linked histories and with short or long life courses. This is vividly exemplified by the Pile hoard ritually deposited in a wetland circa 2000 BC with a content of new and old, local and foreign, exotic and ordinary, and complete and broken items, none of which were meant to be retrieved again by living persons. The state of brokenness nevertheless reflects the work of a smith who resided in the nearby settlement (Vandkilde 2017b). However, differences in the compositions and 
fragmentation patterns within metalwork hoards, as well as other evidence of the peri-depositional treatment of objects, in many cases do make for a clear distinction between assemblages deposited for their symbolic value on the one hand and those deposited for their material value as commodities on the other, regardless of their likely character as votive offerings in both instances (Brandherm 2016; Brandherm and Moskal-del Hoyo 2014). It is important to distinguish between the motives behind the intentional fragmentation of objects, on the one hand, and the rationale for their deposition on the other. With some categories of hoards, these are intricately linked, but not so with others.

\section{Conclusions and Directions for Future Research}

The widespread use and preservation of copper and bronze, together with the long traditions of scholarship surrounding archaeological metal objects, and latterly metal production, make it a fundamental material for understanding societies in Bronze Age Europe. Numerous projects over the last half-century have applied sciencebased approaches to the study of metalwork to address archaeological questions of alloy selection, development, distribution, and provenance, the latter long considered the "Holy Grail" of the discipline. We are witnessing the problems of data compatibility, issues of sample selection, lack of documentation, and isolated (regional) case studies. Responses to our questions are not straightforward, even when cuttingedge analytical tools are being used. Chemical analyses can exhibit meaningful patterning for classification and provenance as well as for models of metal circulation. However, we need to be cautious about the high-resolution detail of this patterning and with the fact that we may see what we want to see-that is what fits well with the existing (or our preferred) narratives.

A single perspective or single strand of evidence is never sufficient for building explanatory models of the past. We need to ensure that the models we make show statistical significance, are based on open data, and ideally on archived sample material. Any data analysis must be replicable and samples available for reanalysis, making it possible for future generations of archaeologists to (re)address them with more advanced scientific methods. It is our responsibility to leave a (data) legacy that is as thoroughly documented as possible. We also notice the growing importance of the careful reconstruction of past smelting/melting practices, both experimentally and theoretically, which could provide useful models for understanding the whole production chain and eventual loss of elements during these operations. This knowledge of metal making also emerges as ever so important in the discussions of connectivity in the European Bronze Age, in particular the acknowledgment of the modes and extent of transmission of ideas and/or skills while mapping the small- and largedistance connectedness during this period.

At present, we see a rather dynamic "metallurgical landscape" during the European Bronze Age, with numerous local and regional metal producers feeding the demand for metal, mostly copper and copper alloys. Eventually, some of these producers gained super-regional importance, possibly together with (or aided by) a recognizable "brand value," such as the neck-ring and rib ingots of central Europe in 
the first half of the second millennium $\mathrm{BC}$ or the oxhide ingots of the Mediterranean during the later Bronze Age (from c. 1600/1500 BC). Some of the large centers produced relatively low-impurity copper from large and consistent ore deposits, such as the chalcopyrite veins in the eastern Alps or the ophiolitic copper deposits in Cyprus, serving large regions with relatively limited material interaction among these regions. The loss of copper through regular attrition as well as hoard deposition and other forms of burial or loss requires ongoing replenishment from geological sources and constrains the minimum amounts of fresh copper that need to be produced annually to maintain metal supply in a given society and to sustain population growth.

The recycling of metal is closely related to the notion of metal value, both as a material and for functional or ideological purposes. However, details of how, when, at what rate, and the degree to which it occurred are still obscure and delineate an important field of study to pursue. While metal consumption in the Early Bronze Age seems to have been restricted to the elites, metal objects seemingly had a much wider application, including other social sectors in the Late Bronze Age and leading to yet another boost of metal production and consumption. It is important that we test, based on archaeological data, such hypotheses. Some would argue that the notion of recycling rates being linked with Early Bronze Age "expansion" is too general to be useful and that a more detailed approach exploring where specific objects and assemblages may have been melted, mixed, and otherwise manipulated is required.

From the mid-second millennium BC onward, we see the appearance of hoards that contain broken metal objects, which traditionally have been interpreted as stored scrap metal for future recycling. However, their ritual connotation remains a potential explanation, too. In this light, many scholars emphasize that weapons, such as swords, were unlikely produced from scrap metal, since their composition and hence the properties of the resulting alloy could not have been controlled. For instance, some scrap components such as lead would have had a detrimental effect on the fracture strength and hence endanger the user of any weapon made from such recycled lead-rich metal. The use of fresh metal for sword making is further corroborated by the research by Jung et al. (2011) and Jung and Mehofer (2013), who showed that the Late Bronze Age swords can be traced back to their source regions. Noteworthy, though, is a different approach that compares the metal stock of British Late Bronze Age swords with that of socketed axes; both classes of objects were drawn from the same, highly recycled metal supply. It is argued that the smiths at the time were drawing no distinction between sword-appropriate or axe-appropriate metal, with the same leaded-bronze being ubiquitous for several centuries (Bray 2016).

Recycling may have become more substantial toward the end of the second millennium BC, but the internal organization of the Bronze Age metal stock, in terms of (re)casting, mixing, alloying, curation, value attribution, and organization of production and distribution, are challenging concepts; still far too little is known to develop detailed models based on archaeological evidence. However, the continued dialogue across specialisms and collaborations on focused archaeological questions should continue to reward the field. To understand trends observed in the data available 
to date, such as the increasing production of low-impurity copper in some regions, requires a wide range of interdisciplinary talents.

Much debate is ongoing concerning the material and social value of copper and bronze, and how this is reflected in the selective depositing of certain artifact types and copper varieties as votive or utilitarian hoards. This is closely linked to the discussion of long-distance trade of certain copper types as part of the pan-European Bronze Age economic setting, but it also affects the evolving specialization of labor and the emergence of mining communities in mountainous areas unsuitable for subsistence based on agriculture alone.

Pulling these various strands of research together shows the huge potential of integrated research approaches that consider all these aspects of the role of metal in the European Bronze Age and emphasizes the need for research that is conscious of its neighboring aspects. Such research ought to maintain a basis of data compatibility and accessibility that promotes dialogue and cross-disciplinary research, spanning the geological and geochemical foundations to the various metallurgical processes of primary production and secondary manufacturing through to social and economic values, drivers, and constraints, all in the quest to better understand the human actions, thoughts, and beliefs behind the archaeological record. Along with the central importance of scientific compatibility and data access, we must finally stress the human factor and the importance of collegiality. At a time of tremendous upheaval in European archaeology, particularly in terms of funding, access, and career structure, we must maintain friendly, positive, and wide collaborations. Collaborating across the diversity of approaches and viewpoints in European Bronze Age archaeometallurgy makes this diversity a tremendous asset rather than hindrance for future research.

Acknowledgments First and foremost, we acknowledge the fundamental previous scholarship, in a multitude of languages and academic fora, on which all our own work is based, implicitly or explicitly, and without which any of this debate would be impossible. It is impossible within the limits of a paper such as this to do justice to this foundational research, and we apologize for any omissions of relevant contributions despite our intention here of being as inclusive as possible. Much of the research referred to here has been very generously supported by numerous funding bodies, as individually acknowledged in the respective original publications; it is hoped that the combination of individual results will add further value to these, beyond the original outcomes. The contribution to our developing thinking on the matters discussed here from colleagues, students, and the wider public is often difficult to pinpoint but continues to be essential for any progress to be made. Comments from anonymous reviewers have helped us improve the paper; any remaining shortcomings are our own. We thank J. Pendić, T. P. Leppard, and E. Caswell for preparing the illustrations for this article. Finally, we are grateful to the University of Cambridge McDonald Institute for Archaeological Research for having hosted the workshop upon which this paper is based.

Open Access This article is distributed under the terms of the Creative Commons Attribution 4.0 International License (http://creativecommons.org/licenses/by/4.0/), which permits unrestricted use, distribution, and reproduction in any medium, provided you give appropriate credit to the original author(s) and the source, provide a link to the Creative Commons license, and indicate if changes were made. 


\section{References Cited}

Albaréde, F., Desaulty, A. M., and Blichert-Toft, J. (2012). A geological perspective on the use of Pb isotopes in archaeometry. Archaeometry 54: 853-867.

Anthony, D. W. (2007). The Horse, the Wheel, and Language: How Bronze-Age Riders from the Eurasian Steppes Shaped the Modern World, Princeton University Press, Princeton, N.J.

Armada, X.-L., and Martinón-Torres, M. (2016). The ALBIMEH Project-Atlantic Late Bronze Age metal hoards compared. Archaeology International 19: 49-53.

Artioli, G., Angelini, I., Nimis, P., Addis, A., and Villa, I. M. (2014). Prehistoric copper metallurgy in the Italian Eastern Alps: Recent results. Historical Metallurgy 47: 51-59.

Artioli, G., Angelini, I., Nimis, P., and Villa, I. M. (2016). A lead-isotope database of copper ores from the southeastern Alps: A tool for the investigation of prehistoric copper metallurgy. Journal of Archaeological Science 75: 27-39.

Bagley, R. G. (2014). Erligang bronzes and the discovery of the Erligang culture. In Steinke, K., and Ching, D. C. Y. (eds.), Art and Archaeology of the Erligang Civilization, Trustees of Princeton University, Princeton, pp. 19-48.

Balliana, E., Aramendía, M., Resano, M., Barbante, C., and Vanhaecke, F. (2013). Copper and tin isotopic analysis of ancient bronzes for archaeological investigation: Development and validation of a suitable analytical methodology. Analytical and Bioanalytical Chemistry 405: 2973-2986.

Bartelheim, M. (2007). Die Rolle der Metallurgie in Vorgeschichtlichen Gesellschaften, Forschungen zur Archäometrie und Altertumswissenschaft 2, Leidorf, Marie Leidorf, Rahden/Westf.

Bass, G. F. (1967). Cape Gelidonya: A Bronze Age shipwreck. Transactions of the American Philosophical Society 57: 1-177.

Bech, J. H., and Mikkelsen, M. (1999). Landscapes, settlement and subsistence in Bronze Age Thy, NW Denmark. In Fabech, C., and Ringtved, J. (eds.), Settlement and Landscape: Proceedings of a Conference in Århus, Denmark May 4-7, 1998, Jysk Arkæologisk Selskab, Højbjerg, pp. 69-77.

Begemann, F., Schmitt-Strecker, S., and Pernicka, E. (1992). The metal finds from Thermi III-V: A chemical and lead isotope study. Studia Troica 2: 219-243.

Berger, D., Brügmann, G., Figueiredo, E., and Pernicka, E. (2016). Zinnisotopenverhältnisse von Verhüttungsprodukten von Kassiterit und ihre Bedeutung für die Herkunftsbestimmung von Zinn. In Greiff, S., Kronz, A., Schlütter, F., and Prange, M. (eds.), Archäometrie und Denkmalpflege 2016, Metalla, Sonderheft 8, Deutsches Bergbau-Museum Bochum, Bochum, pp. 194-197.

Berger, D., Brügmann, G., and Pernicka, E. (2017). On smelting cassiterite in geological and archaeological samples: Preparation and implications for provenance studies on metal artefacts with tin isotopes. Archaeological and Anthropological Sciences online, https://doi.org/10.1007/s1252 0-017-0544-z.

Betancourt, P. P. (2006). The Chrysokamino Metallurgy Workshop and Its Territory, American School of Classical Studies at Athens, Athens.

Boroffka, N., Cierny, J., Lutz, J., Parzinger, H., Pernicka, E., and Weisgerber, G. (2002). Bronze Age tin from central Asia. In Boyle, K., Renfrew, C., and Levine, M. (eds.), Ancient Interactions: East and West in Eurasia, McDonald Institute Monographs, Cambridge, pp. 135-159.

Boroffka, N., and Heck, G. (2006). Resursele minerale din România şi stadiul actual al cercetărilor privind mineritul preistoric. Apulum 43: 71-94.

Boulud, S., and Mélin, M. (2009). Étude comparative des modalités de dépôt en milieu terrestre et en milieux humides en région armoricaine à l'âge du Bronze final. In Bonnardin, S., Hamon, C., Lauwers, M., and Quilliec, B. (eds.), Du matériel au spirituel: Réalités archéologiques et historiques des «dépôts» de la préhistoire à nos jours, XXIXe Rencontres Internationales d'Archéologie et d'Histoire d'Antibes, Éditions APDCA, Antibes, pp. 249-260.

Bourgarit, D. (2007). Chalcolithic copper smelting. In La Niece, S., Hook, D., and Craddock, P. (eds.), Metals and Mines: Studies in Archaeometallurgy, Archetype Publications, London, pp. 3-14.

Bradley, R. (1985). Exchange and social distance: The structure of bronze artefact distributions. Man 20: $692-704$.

Bradley, R. (1998). The Passage of Arms, Oxbow, Oxford.

Bradley, R. (2017). A Geography of Offerings: Deposits of Valuables in the Landscapes of Ancient Europe, Oxbow, Oxford. 
Brandherm, D. (2004). Ein neuer Fund eines Langquaidbeils und einer Lanzenspitze aus Speyer: Zum Beginn und zur Deutung der Brucherzdeponierungssitte in Süddeutschland. Archäologisches Korrespondenzblatt 34: 357-374.

Brandherm, D. (2016). Zur Deutung der endbronzezeitlichen Waffendeponierung aus der Ría de Huelva: Eine Fallstudie zur Mustererkennung und -deutung in multifunktionstypisch zusammengesetzten Mehrstückdeponierungen der europäischen Bronzezeit. In Dietz, U. L., and Jockenhövel, A. (eds.), 50 Jahre Prähistorische Bronzefunde. Bilanz und Perspektiven, Beiträge zum internationalen Kolloquium vom 24 bis 26 September 2014 in Mainz, Prähistorische Bronzefunde XX/14, Steiner, Stuttgart, pp. 61-98.

Brandherm, D., and Moskal-del Hoyo, M. (2014). Both sides now: The carp's-tongue complex revisited. Antiquaries Journal 94: 1-47.

Bray, P. (2016). Metal, metalwork and specialisation: The chemical composition of British Bronze Age swords in context. In Koch, J. (ed.), Celts from the West III: Proceedings of the AEMA Conference, Cardiff 2014, Centre for Welsh and Celtic Studies, University of Aberystwyth, Cardiff, pp. 229-246.

Bray, P., Cuénod, A., Gosden, C., Hommel, P., Liu, R., and Pollard, A. M. (2015). Form and flow: The 'karmic cycle' of copper. Journal of Archaeological Science 56: 202-209.

Bray, P., and Pollard, A. M. (2012). A new interpretative approach to the chemistry of copper-alloy objects: Source, recycling and technology. Antiquity 86: 853-867.

Briard, J. (1995). L'Âge du Bronze. In Giot, P.-R., Briard, J., and Pape, L. (eds.), Protohistoire de la Bretagne, 2nd edition, Éditions Ouest-France, Rennes, pp. 25-198.

Broodbank, C. (2013). The Making of the Middle Sea: A History of the Mediterranean from the Beginning to the Emergence of the Classical World, Thames and Hudson, London.

Brügmann, G., Berger, D., and Pernicka, E. (2017). Determination of the tin stable isotopic composition in tin-bearing metals and minerals by MC-ICP-MS. Geostandards and Geoanalytical Research 41: $437-448$.

Budd, P. (1991). Eneolithic arsenical copper: Heat-treatment and the metallographic interpretation of manufacturing processes. In Pernicka, E., and Wagner, G. A. (eds.), Archaeometry '90: International Symposium on Archaeometry, Birkhäuser Verlag, Heidelberg, pp. 35-44.

Bunnefeld, J., and Schwenzer, S. (2011). Traditionen, Innovationen und Technologietransfer zur Herstellungstechnik und Funktion älterbronzezeitlicher Schwerter in Niedersachsen. Prähistorische Zeitschrift 86: 207-253.

Butler, J. J. (1979). Rings and ribs: The copper types of the "ingot hoards" of the central European Early Bronze Age. In Ryan, M. (ed.), The Origins of Metallurgy in Atlantic Europe: Proceedings of the Fifth Atlantic Colloquium, Dublin, 30th March to 4th April 1978, Stationery Office, Dublin, pp. 345-362.

Case, H. J. (1954). Studies of Irish and British early copper artefacts: Second series, Reports of the Ancient Mining and Metallurgy Committee of the Royal Anthropological Institute. Man 54: 18-27.

Charlton, M. F., Blakelock, E., Martinón-Torres, M., and Young, T. (2012). Investigating the production provenance of iron artifacts with multivariate methods. Journal of Archaeological Science 39: 2280-2293.

Chase, W. T. (1974). Comparative analysis of archaeological bronzes. In Beck, C. W. (ed.), Archaeological Chemistry, Advances in Chemistry Series No. 138, American Chemical Society, Washington, DC, pp. 148-185.

Chen, K., Mei, J., Rehren, Th., and Zhao, C. (2016). Indigenous production and interregional exchange: Late second-millennium BC bronzes from the Hanzhong basin, China. Antiquity 90: 665-678.

Chernykh, E. N. (1978). Gornoe Delo i Metallurgiya v Dreivneishei Bolgarii, Bolgarskoi Akademii Nauk, Sofia.

Chernykh, E. N. (1992). Ancient Metallurgy in the USSR: The Early Metal Age, Cambridge University Press, Cambridge.

Chernykh, E. N. (2013). Nomadic Cultures in the Mega-Structure of Eurasian World, Vol 1 (in Russian), Jaziki Slavjanskoi Kulturi, Moscow.

Cline, E. H. (ed.) (2010). The Oxford Handbook of the Bronze Age Aegean (ca. 3000-1000 BC), Oxford University Press, Oxford.

Coghlan, H. H., and Case, H. J. (1957). Early metallurgy of copper in Ireland and Britain. Proceedings of the Prehistoric Society 23: 91-123. 
Coghlan, H. H., and Cook, M. (1953). Studies of British and Irish celts: First Series, Reports of the Ancient Mining and Metallurgy Committee of the Royal Anthropological Institute. Man 53: 97-101.

Coles, J. (1970). Review of Kupfer und Bronze in der frühen Metallzeit Europas: Studien zu den Anfängen der Metallurgie, 2 (S. Junghans, E. Sangmeister, and M. Schröder). Antiquity 44: 233-234.

Craddock, P. T. (1976). The composition of the copper alloys used by the Greek, Etruscan and Roman civilizations 1: The Greeks before the Archaic period. Journal of Archaeological Science 3: 93-113.

Craddock, P. T. (1978). The composition of the copper alloys used by the Greek, Etruscan and Roman civilizations 3: The origins and early use of brass. Journal of Archaeological Science 5: 1-16.

Craddock, P. T. (1985). Three thousand years of copper alloys: From the Bronze Age to the Industrial Revolution. In England, P. A., and Van Zelst, L. (eds.), Application of Science in Examination of Works of Art: Proceedings of the Seminar, September 7-9, 1983, Research Laboratory, Museum of Fine Arts, Boston, pp. 59-67.

Craddock, P. T. (1995). Early Metal Mining and Production, Edinburgh University Press, Edinburgh.

Cuénod, A., Bray, P., and Pollard, A. M. (2015). The "tin problem'" in the prehistoric Near East: Further insights from a study of chemical datasets on copper alloys from Iran and Mesopotamia. Iran 53: $29-48$.

Dietrich, O. (2014). Learning from 'scrap' about Late Bronze Age hoarding practices: A biographical approach to individual acts of dedication in large metal hoards of the Carpathian Basin. European Journal of Archaeology 17: 468-486.

Dietz, U. L., and Jockenhövel, A. (eds.) (2016). 50 Jahre Prähistorische Bronzefunde: Bilanz und Perspektiven, Beiträge zum internationalen Kolloquium vom 24 bis 26 September 2014 in Mainz, Prähistorische Bronzefunde XX/14, Franz Steiner Verlag, Stuttgart.

Dimitrov, K. (2002). Die Metallfunde aus den Gräberfeldern von Durankulak. In Todorova, H. (ed.), Durankulak, Band II: Die prähistorischen Gräberfelder von Durankulak, Teil 1, Publishing House Anubis, Berlin-Sofia, pp. 127-158.

Dolfini, A., and Crellin, R. J. (2016). Metalwork wear analysis: The loss of innocence. Journal of Archaeological Science 66: 78-87.

Duberow, E., Pernicka, E., and Krenn-Leeb, A. (2009). Eastern Alps or Western Carpathians: Early Bronze Age metal within the Wieselburg culture. In Kienlin, T. L., and Roberts, B. W. (eds.), Metals and Societies, Studies in Honour of Barbara S. Ottaway, Universitätsforschungen zur Prähistorischen Archäologie, Band 169, Habelt, Bonn, pp. 336-349.

Ducke, B., and Rassmann, K. (2010). Modellierung und Interpretation der Kommunikationsräume des 3. und frühen 2. Jahrtausends v. Chr. in Europa mittels Diversitätsgradienten. Archäologischer Anzeiger 2010/1: 239-261.

Earle, T. K., and Kolb, M. (2010). Regional settlement patterns. In Earle, T. K., and Kristiansen, K. (eds.), Organizing Bronze Age Societies, Cambridge University Press, Cambridge, pp. 57-86.

Earle, T. K., Ling, J., Uhnér, C., Stos-Gale, Z. A., and Melheim, L. (2015). The political economy and metal trade in Bronze Age Europe: Understanding regional variability in terms of comparative advantages and articulations. European Journal of Archaeology 18: 633-657.

Farci, C., Martinón-Torres, M., and Álvarez, D. G. (2017). Bronze production in the Iron Age of the Iberian Peninsula: The case of El Castru, Vigaña (Asturias, NW Spain). Journal of Archaeological Science: Reports 11: 338-351.

Figueiredo, E., Silva, R. J. C., Senna-Martinez, J. C., Araújo, M. F., Braz Fernandes, F. M., and Inês Vaz, J. L. (2010). Smelting and recycling evidences from the Late Bronze Age habitat site of Baiões (Viseu, Portugal). Journal of Archaeological Science 37: 1623-1634.

Fokkens, H., and Harding, A. F. (eds.) (2013). The Oxford Handbook of the European Bronze Age, Oxford University Press, Oxford.

Fontanals, N. R., Soriano, I., and Delgado-Raack, S. (eds.) (2017). A Prehistoric Copper Mine in the North-East of the Iberian Peninsula: Solana del Bepo (Ulldemolins, Tarragona), Universitat de Lleida, Lleida.

Fontijn, D. R. (2002). Sacrificial Landscapes: Cultural Biographies of Persons, Objects and Natural Places in the Bronze Age of the Southern Netherlands c. 2300-600 BC, Analecta Praehistorica Leidensia 33/34, University of Leiden Faculty of Archaeology, Leiden.

Forel, B., Gabillot, M., Monna, F., Forel, S., Dommergues, C. H., Gerber, S., Petit, C., Mordant, C., and Chateau, C. (2009). Morphometry of Middle Bronze Age palstaves by discrete cosine transform. Journal of Archaeological Science 36: 721-729. 
Frachetti, M. D. (2008). Pastoralist Landscapes and Social Interaction in Bronze Age Eurasia, University of California Press, Berkeley.

Frank, C., and Pernicka, E. (2012). Copper artefacts of the Mondsee group and their possible sources. In Midgley, M. S., and Sanders, J. (eds.), Lake Dwellings after Robert Munro. Proc. Munro Int. Seminar: The Lake Dwellings of Europe, 22 and 23 October 2010, University of Edinburgh, Leiden, pp. $113-138$.

Frei, K. M., Mannering, U., Kristiansen, K., Allentoft, M. E., Wilson, A. S., Skals, I., Tridico, S., Nosch, M. L., Willerslev, E., Clarke, L., and Frei, R. (2015). Tracing the dynamic life story of a Bronze Age female. Scientific Reports 5: 10431, https://doi.org/10.1038/srep10431.

Frei, K. M., Villa, C., Jørkov, M. L., Allentoft, M. E., Kaul, F., Ethelberg, P., Reiter, S. S., Wilson, A. S., Taube, M., Olsen, J., Lynnerup, N., Willerslev, E., Kristiansen, K., and Frei, R. (2017). A matter of months: High precision migration chronology of a Bronze Age female. PLoS ONE 12: e0178834, https://doi.org/10.1371/journal.pone.0178834.

Gale, N. H., and Stos-Gale, Z. A. (2000). Lead isotope analyses applied to provenance studies. In Ciliberto, E., and Spoto, G. (eds.), Modern Analytical Methods in Art and Archaeology, Chemical Analyses Series, Vol. 155, John Wiley and Sons, New York, pp. 503-584.

Gale, N. H., and Stos-Gale, Z. A. (2005). Zur Herkunft der Kupferbarren aus dem Schiffswrack von Uluburun und der spätbronzezeitliche Metallhandel im Mittelmeerraum. In Yalcin, U., Pulak, C., and Slotta, R. (eds.), Das Schiff von Uluburun: Welthandel vor 3000 Jahren, Deutsches BergbauMuseum, Boshum, pp. 117-132.

Gale, N. H., and Stos-Gale, Z. A. (2012). The role of the Apliki mine region in the post c. 1400 BC copper production and trade networks in Cyprus and the wider Mediterranean. In Kassianidou, V., and Papasavvas, G. (eds.), Eastern Mediterranean Metallurgy and Metalwork in the Second Millennium BC, Oxbow Books, Oxford, pp. 70-83.

Gale, N. H., Stos-Gale, Z. A., Raduncheva, A., Panayotov, I., Ivanov, I., Lilov, P., and Todorov, T. (2003). Early metallurgy in Bulgaria. In Craddock, P., and Lang, J. (eds.), Mining and Metal Production Through the Ages, British Museum Press, London, pp. 122-173.

Garner, J. (2014). Das Zinn der Bronzezeit in Mittelasien II: Die montanarchäologischen Forschungen an den Zinnlagerstätten, Deutsches Bergbau-Museum, Bochum.

Gernez, G. (2013). Une exceptionnelle découverte à Tell Mabtouh Sharqi: Les dépôts d'armes et objets en métal du Temple N: Etude préliminaire. Studia Orontica 11: 41-57.

Giumlia-Mair, A., and Lo Schiavo, F. (eds.) (2003). The Problem of Early Tin: Actes of the 14th UISPP Congress, University of Liège, Belgium, 2-8 September 2001, Archaeopress, Oxford.

Gomez-Ramos, P. (1993). Tipologia de lingotes de metal y su hallazgo en los depositos del Bronce final de la peninsula ibérica. Cuadernos de Préhistoria y de Archéologia de la Universidad Autónoma de Madrid 20: 73-105.

Gutiérrez-Sáez, C., and Martín-Lerma, I. (2015). Traceology on metal: Use-wear marks on copper-based tools and weapons. In Marreiros, J., Gibaja, J. F., and Bicho, N. (eds.), Use-wear and Residue Analysis in Archaeology, Springer, New York, pp. 171-188.

Hansen, S. (2013). Bronzezeitliche Deponierungen in Europa nördlich der Alpen. Weihgaben ohne Tempel. In Raue, D., and Gerlach, I. (eds.), Sanktuar und Ritual: Heilige Plätze im Archäologischen Befund, Marie Leidorf, Rahden/Westf., pp. 371-388.

Harding, A. F. (2000). European Societies in the Bronze Age, Cambridge University Press, Cambridge.

Harding, A. F. (2013). World systems, cores, and peripheries in prehistoric Europe. European Journal of Archaeology 16: 378-400.

Härke, H. (1978). Probleme der optischen Emissionsspektralanalyse in der Urgeschichtsforschung. Prähistorische Zeitschrift 53: 165-276.

Hauptmann, A. (2014). The investigation of archaeometallurgical slag. In Roberts, W. B., and Thornton, P. C. (eds.), Archaeometallurgy in Global Perspective: Methods and Syntheses, Springer, New York, pp. 91-105.

Hauptmann, A., Maddin, R., and Prange, M. (2002). On the structure and composition of copper and tin ingots excavated from the shipwreck of Uluburun. Bulletin of the American Schools of Oriental Research 328: 1-30.

Haustein, M., Gillis, C., and Pernicka, E. (2010). Tin isotopy: A new method for solving old questions. Archaeometry 52: 816-832.

Hodson, F. R. (1969). Searching for structure within multivariate archaeological data. World Archaeology 1: $90-105$. 
Holst, M. K., Rasmussen, M., Kristiansen, K., and Bech, J.-H. (2013). Bronze Age 'Herostrats': Ritual, political, and domestic economies in Early Bronze Age Denmark. Proceedings of the Prehistoric Society 79: 265-296.

Höppner, B., Bartelheim, M., Huijsmans, M., Krauss, R., Martinek, K. P., Pernicka, E., and Schwab, R. (2005). Prehistoric copper production in the Inn Valley (Austria), and the earliest copper in central Europe. Archaeometry 47: 293-315.

Horn, C. (2013). Weapons, fighters and combat: Spears and swords in Early Bronze Age Scandinavia. Danish Journal of Archaeology 2: 20-44.

Hsu, Y.-K., Bray, P. J., Hommel, P., Pollard, A. M., and Rawson, J. (2016). Tracing the flows of copper and copper alloys in the Early Iron Age societies of the eastern Eurasian steppe. Antiquity 90: $357-375$.

Hunt-Ortiz, M. A. (2003). Prehistoric Mining and Metallurgy in South-West Iberian Peninsula, BAR International Series 1188, Archaeopress, Oxford.

Jockenhövel, A. (2016). 50 Jahre Prähistorische Bronzefunde: Versuch einer ersten Bilanz. In Dietz, U. L., and Jockenhövel, A. (eds.), 50 Jahre Prähistorische Bronzefunde: Bilanz und Perspectiven, Beiträge zum internationalen Kolloquium vom 24 bis 26 September 2014 in Mainz, Prähistorische Bronzefunde XX/14, Franz Steiner Verlag, Stuttgart, pp. 1-32.

Jung, R., and Mehofer, M. (2013). Mycenaean Greece and Bronze Age Italy: Cooperation, trade or war? Archäologisches Korrespondenzblatt 43: 175-192.

Jung, R., Mehofer, M., and Pernicka, E. (2011). Metal exchange in Italy from the Middle to the Final Bronze Age (14th-11th century BCE). In Betancourt, P. P., and Ferrence, S. C. (eds.), Metallurgy: Understanding How, Learning Why: Studies in Honor of James D. Muhly, Prehistory Monographs 29, INSTAP Academic Press, Philadelphia, pp. 231-248.

Junghans, S., Klein, H., and Scheufele, E. (1954). Untersuchungen zur Kupfer- und Frühbronzezeit Süddeutschlands. Bericht der Römisch-Germanischen Kommission 34: 77-114.

Junghans, S., Sangmeister, E., and Schröder, M. (1960). Metallanalysen kupferzeitlicher und frühbronzezeitlicher Bodenfunde aus Europa, Mann, Berlin.

Junghans, S., Sangmeister, E., Schröder, M. (1968). Kupfer und Bronze in der frühen Metallzeit Europas: Studien zu den Anfängen der Metallurgie, 1-3, Mann, Berlin.

Junghans, S., Sangmeister, E., and Schröder, M. (1974). Kupfer und Bronze in der frühen Metallzeit Europas: Studien zu den Anfängen der Metallurgie, 4, Mann, Berlin.

Junk, M., Krause, R., and Pernicka, E. (2001). Ösenringbarren and the classical Ösenring Copper. In Metz, W. H., van Beek, B. L., Steegstra, H. (eds.), PATINA: Essays Presented to Jay Jordan Butler on the Occasion of his 80th Birthday, Metz, Van Beek \& Steegstra, Groningen, pp. 353-366.

Kienlin, T. L. (2015). Bronze Age Tell Communities in Context-An Exploration Into Culture, Society and the Study of European Prehistory, Part 1-Critique: Europe and the Mediterranean, Archaeopress, Oxford.

Kienlin, T. L. (2017). World systems and the structuring potential of foreign-derived (prestige) goods: On modelling Bronze Age economy and society. In Scholz, A. K., Bartelheim, M., Hardenberg, R., and Staecker, J. (eds.), Resource Cultures: Sociocultural Dynamics and the Use of ResourcesTheories, Methods, Perspectives, University of Tübingen, Tübingen, pp. 143-157.

Killick, D. (2014). From ores to metals. In Roberts, B. W., and Thornton, C. P. (eds.), Archaeometallurgy in Global Perspective: Methods and Syntheses, Springer, New York, pp. 11-45.

Klassen, L. (2000). Frühes Kupfer im Norden: Untersuchungen zu Chronologie, Herkunft und Bedeutung der Kupferfunde der Nordgruppe der Trichterbecherkultur, Jutland Archaeological Society 36, Aarhus University Press, Aarhus.

Klassen, L. (2004). Jade und Kupfer: Untersuchungen zum Neolithisierungsprozess im westlichen Ostseeraum unter besonderer Berücksichtigung der Kulturentwicklung Europas 5500-3500 BC, Jutland Archaeological Society 47, Moesgård Museum, Aarhus.

Klassen, L., and Pernicka, E. (1998). Eine kreuzschneidige Axthacke aus Südskandinavien? Ein Beispiel für die Anwendungsmöglichkeiten der Stuttgarter Analysedatenbank. Archäologisches Korrespondenzblatt 28: 35-45.

Kohl, P. L. (2007). The Making of Bronze Age Eurasia, Cambridge University Press, Cambridge.

Krause, R. (2003). Studien zur kupfer- und frühbronzezeitlichen Metallurgie zwischen Karpatenbecken und Ostsee, Vorgeschichtliche Forschungen 24, Marie Leidorf, Rahden.

Krause, R., and Pernicka, E. (1996). Das neue Stuttgarter Metallanalysenprojekt "SMAP.” Archäologisches Nachrichtenblatt 1: 274-291. 
Kristiansen, K. (1978). The consumption of wealth in Bronze Age Denmark: A study in the dynamics of economic processes in tribal societies. In Kristiansen, K., and Paludan-Müller, C. (eds.), New Directions in Scandinavian Archaeology, National Museum of Denmark, Copenhagen, pp. $158-190$.

Kristiansen, K. (1984). Krieger und Häuptlinge in der Bronzezeit Dänemarks: Ein Beitrag zur Geschichte des bronzezeitlichen Schwertes. Jahrbuch Des Römisch-Germanischen Zentralmuseums 31: $187-208$.

Kristiansen, K. (2002). The tale of the sword: Swords and swordfighters in Bronze Age Europe. Oxford Journal of Archaeology 21: 319-332.

Kristiansen, K. (2017). Interpreting Bronze Age trade and migration. In Kiriatzi, E., and Knappett, C. (eds.), Human Mobility and Technological Transfer in the Prehistoric Mediterranean, Cambridge University Press, Cambridge, pp. 154-181.

Kristiansen, K., and Larsson, T. (2005). The Rise of Bronze Age Society: Travels, Transmissions and Transformations, Cambridge University Press, Cambridge.

Kristiansen, K., and Suchowska-Ducke, P. (2015). Connected histories: The dynamics of Bronze Age interaction and trade 1500-1100 BC. Proceedings of the Prehistoric Society 81: 361-392.

Krüger, J., Nagel, F., Nagel, S., Jantzen, D., Lampe, R., Dräger, J., Lidke, G., Mecking, O., Schüler, T., and Terberger, T. (2012). Bronze Age tin rings from the Tollense Valley in northeastern Germany. Prähistorische Zeitschrift 87: 29-43.

Kuijpers, M. H. (2017). The Bronze Age, a world of specialists Metalworking from the perspective of skill and material specialization. European Journal of Archaeology, doi: https://doi.org/10.1017/ eaa.2017.59.

Kuijpers, M. H. (2018). An Archaeology of Skill: Metalworking Skill and Material Specialization in Early Bronze Age Central Europe, Routledge, London.

Kuzmina, E. E. (2008). The Prehistory of the Silk Road, University of Pennsylvania Press, Philadelphia.

Larsen, M. T. (2015). Ancient Kanesh: A Merchant Colony in Bronze Age Anatolia, Cambridge University Press, Cambridge.

Le Carlier, C. L., Edme, M., and Fily, M. (2014). Lingots et déchets de fonderie dans les dépôts de l'horizon de l'épée à pointe en langue de carpe (Bronze final IIIb): Proposition de typologie. Bulletin de la Société Préhistorique Française 111: 509-522.

Lechtman, H. (1996). Arsenic bronze: Dirty copper or chosen alloy? A view from the Americas. Journal of Field Archaeology 23: 477-514.

Lenerz-de Wilde, M. (1995). Prämonetäre Zahlungsmittel in der Kupfer- und Bronzezeit Mitteleuropas. Fundberichte aus Baden-Württemberg 20: 229-327.

Lenerz-de Wilde, M. (2002). Bronzezeitliche Zahlungsmittel. Mitteilungen der Anthropologischen Gesellschaft in Wien 132: 1-23.

Leusch, V., Armbruster, B., Pernicka, E., and Slavčev, V. (2015). On the invention of gold metallurgy: The gold objects from the Varna I cemetery (Bulgaria)-Technological consequence and inventive creativity. Cambridge Archaeological Journal 25: 353-376.

Li, X. J., Bevan, A., Martinón-Torres, M., Rehren, Th., Cao, W., Xia, Y., and Zhao, K. (2014). Crossbows and imperial craft organisation: The bronze triggers of China's Terracotta Army. Antiquity 88: $126-140$.

Ling, J., Earle, T. K., and Kristiansen, K. (in press). Maritime mode of production: Raiding and trading in seafaring chiefdoms. Current Anthropology.

Ling, J., Hjärthner-Holdar, E., Grandin, L., Billström, K., and Persson, P.-O. (2013). Moving metals or indigenous mining? Provenancing Scandinavian Bronze Age artefacts by lead isotopes and trace elements. Journal of Archaeological Science 40: 291-304.

Ling, J., and Stos-Gale, Z. A. (2015). Representations of oxhide ingots in Scandinavian rock art: The sketchbook of a Bronze Age traveller? Antiquity 89: 191-209.

Ling, J., Stos-Gale, Z. A., Grandin, L., Billström, K., Hjärthner-Holdar, E., and Persson, P.-O. (2014). Moving metals II: Provenancing Scandinavian Bronze Age artefacts by lead isotope and elemental analyses. Journal of Archaeological Science 41: 106-132.

Ling, J., and Uhnér, C. (2014). Rock art and metal trade. Adoranten 2014: 23-43.

Liu, L., and Chen, X. (2012). The Archaeology of China: From the Late Paleolithic to the Early Bronze Age, Cambridge University Press, Cambridge.

Liu, S., Chen, K. L., Rehren, Th., Mei, J., Chen, Y., and Killick, D. (2018). Did China import metals from Africa in the Late Bronze Age? Archaeometry 60: 105-117. 
Liversage, D. (1994). Interpreting composition patterns in ancient bronze: The Carpathian Basin. Acta Archaeologica 65: 57-134.

Lo Schiavo, F. (2006). Western weights in context. In Alberti, M. E., Ascalone, E., and Peyronel, L. (eds.), Weights in Context: Bronze Age Weighing Systems of Eastern Mediterranean: Chronology, Typology and Archaeological Contexts: Proceedings of the International Colloquium, Rome (2224 November 2004), Studie Materiali 13, Istituto Italiano di Numismatica, Roma, pp. 359-379.

Lorenz, L. (2010). Typologisch-chronologische Studien zu Deponierungen der nordwestlichen Aunjetitzer Kultur, Universitätsforschungen zur Prähistorischen Archäologie aus dem Institut für Ur- und Frühgeschichte der Universität Kiel, Band 188, Verlag Rudolf Habelt, Bonn.

Loveless, A. J. (1975). Lead isotopes: A guide to major mineral deposits. Geoexploration 13: 13-27.

Lucas-Pellicer, M. R., and Gomez-Ramos, P. (1993). Transporte marítimo del metal como material prima durante del Bronce Final. Cuadernos de Prehistoria y Arqueología de la Universidad Autónoma de Madrid 20: 107-131.

Mahé-le Carlier, C., Lulzac, Y., and Giot, P.-R. (2001). Etude des déchets de réduction provenant de deux sites d'exploitation d'étain armoricain de l'Age du Bronze et du Moyen Age. Revue Archéologique de l'Ouest 18: 45-56.

Maréchal, J.-R. (1958). Etude sur les proprietes mechaniques des cuivres a l'arsenic. Métaux Corrosion Industries 33: 377-383.

Martinón-Torres, M., Li, X., Bevan, A., Xia, Y., Zhao, K., and Rehren, Th. (2014). Forty thousand arms for a single emperor: From chemical data to the labor organization behind the bronze arrows of the Terracotta Army. Journal of Archaeological Method and Theory 21: 534-562.

Martinón-Torres, M., and Rehren, Th. (2014). Technical ceramics. In Roberts, B. W., and Thornton, C. P. (eds.), Archaeometallurgy in Global Perspective: Methods and Syntheses, Springer, New York, pp. 107-131.

Martinón-Torres, M., and Uribe-Villegas, M. A. (2015). The prehistoric individual, connoisseurship and archaeological science: The Muisca goldwork of Colombia. Journal of Archaeological Science 63: $136-155$.

Mason, A. H., Powell, W. G., Bankoff, H. A., Mathur, R., Bulatović, A., Filipović, V., and Ruiz, J. (2016). Tin isotope characterization of bronze artifacts of the central Balkans. Journal of Archaeological Science 69: 110-117.

McGeehan-Liritzis, V., and Taylor, J. W. (1987). Yugoslavian tin deposits and the Early Bronze Age industries of the Aegean region. Oxford Journal of Archaeology 6: 287-300.

McKerrell, H., and Tylecote, R. F. (1972). The working of copper-arsenic alloys in the Early Bronze Age and the effect on the determination of provenance. Proceedings of the Prehistoric Society 38: 209-218.

Meeks, N. (1993). Surface characterization of tinned bronze, high-tin bronze, tinned iron and arsenical bronze. In La Niece, S., and Craddock, P. T. (eds.), Metal Plating and Patination: Cultural, Technical and Historical Developments, Butterworth-Heinemann, Oxford, pp. 247-275.

Menotti, F. (2001). "The Missing Period": Middle Bronze Age Lake-Dwellings in the Alps, Archaeopress, Oxford.

Menotti, F. (ed.) (2004). Living on the Lake in Prehistoric Europe: 150 Years of Lake-Dwellings Research, Routledge, London.

Merideth, C. (1998). An Archaeometallurgical Survey for Ancient Tin Mines and Smelting Sites in Spain and Portugal: Mid-Central Western Iberian Geographical Region 1990-1995, BAR International Series 714, Archaeopress, Oxford.

Merkel, J. (1990). Experimental reconstruction of Bronze Age copper smelting based on archaeological evidence from Timna. In Rothenberg, B. (ed.), The Ancient Metallurgy of Copper: Archaeology, Experiment, Theory, Institute for Archaeo-Metallurgical Studies and UCL Institute of Archaeology, London, pp. 78-122.

Milcent, P.-Y. (2012). Le temps des élites en Gaule atlantique: Chronologie des mobiliers et rythmes de constitution des dépôts métalliques dans le contexte européen (XIIIe-VIIe s. av. J.-C.), Presses Universitaires de Rennes, Rennes.

Mödlinger, M., Kuijpers, M. H. G., Braekmans, D., and Berger, D. (2017). Quantitative comparisons of the color of CuAs, CuSn, CuNi, and CuSb alloys. Journal of Archaeological Science 88: 14-23.

Mödlinger, M., and Sabatini, B. (2016). A Re-evaluation of inverse segregation in prehistoric $\mathrm{As}-\mathrm{Cu}$ objects. Journal of Archaeological Science 74: 60-74.

Molloy, B. (2008). Martial arts and materiality: A combat archaeology perspective on Aegean swords of the fifteenth and fourteenth centuries BC. World Archaeology 40: 116-134. 
Molloy, B. (2009). For gods or men? A reappraisal of the function of European Bronze Age shields. Antiquity 83: 1052-1064.

Molloy, B. (2010). Swords and swordsmanship in the Aegean Bronze Age. American Journal of Archaeology 114: 403-428.

Molloy, B., Wiśniewski, M., Lynam, F., O'Neill, B., O'Sullivan, A., and Peatfield, A. (2016). Tracing edges: A consideration of the applications of 3D modelling for metalwork wear analysis on Bronze Age bladed artefacts. Journal of Archaeological Science 76: 79-87.

Monna, F., Jebrane, A., Gabillot, M., Laffont, R., Specht, M., Bohard, B., Camizuli, E., Petit, C., Chateau, C., and Alibert, P. (2013). Morphometry of Middle Bronze Age palstaves, Part II-Spatial distribution of shapes in two typological groups, implications for production and exportation. Journal of Archaeological Science 40: 507-516.

Montero, I., and Delibes, G. (eds.) (1999). Las primeras etapas metalúrgicas en la Península Ibérica, II: Estudios regionales, Instituto Universitario Ortega y Gasset, Madrid.

Montero Ruiz, I., Benítez De Lugo Enrich, L., Álvarez García, H. J., Gutiérrez-Neira, P. C., Murillo-Barroso, M., Palomares Zumajo, N., Menchén Herreros, G., Moraleda Sierra, J., and Salazar-García, D. (2014). Cobre para los muertos: Estudio arqueométrico del material metálico procedente del monumento megalítico prehistórico de Castillejo del Bonete (Terrinches, Ciudad Real). Zephyrus 73: $109-132$.

Muhly, J. D., Wheeler, T. S., and Maddin, R. (1977). The Cape Gelidonya shipwreck and the Bronze Age metals trade in the eastern Mediterranean. Journal of Field Archaeology 4: 353-362.

Müller, R., Rehren, Th., and Rovira, S. (2004). Almizaraque and the early copper metallurgy of southeast Spain: New data. Madrider Mitteilungen 45: 33-56.

Murgia, A., Roberts, B. W., and Wiseman, R. (2014). What have metal detectorists done for us? A case study of Bronze Age gold in England and Wales. Archäologisches Korrespondenzblatt 44: 353-367.

Murillo-Barroso, M., and Martinón-Torres, M. (2012). Amber sources and trade in the prehistory of the Iberian Peninsula. European Journal of Archaeology 15: 187-216.

Murillo-Barroso, M., Martinón-Torres, M., Massieu, M. D. C., Socas, D. M., and González, F. M. (2017). Early metallurgy in SE Iberia: The workshop of Las Pilas (Mojácar, Almería, Spain). Archaeological and Anthropological Sciences 9: 1539-1569.

Murillo-Barroso, M., Montero Ruiz, I., and Aranda Jiménez, G. (2015). An insight into the organisation of metal production in the Argaric society. Journal of Archaeological Science: Reports 2: 141-155.

Nebelsick, L. D. (2000). Rent asunder: Ritual violence in Late Bronze Age hoards. In Pare, C. (ed.), Metals Make the World go Round: The Supply and Circulation of Metals in Bronze Age Europe, Oxbow Books, Oxford, pp. 160-175.

Needham, S. P. (2002). Analytical implications for Beaker metallurgy in northwest Europe. In Bartelheim, M., Pernicka, E., and Krause, R. (eds.), Die Anfänge der Metallurgie in der Alten Welt, Forschungen zur Archäometrie und Altertumswissenschaft, Band 1, Verlag Marie Leidorf, Rahden, pp. 99-133.

Needham, S. P., Parham, D., and Frieman, C. J. (2013). Claimed by the Sea: Salcombe, Langdon Bay, and Other Marine Finds of the Bronze Age, CBA Research Reports 173, Council for British Archaeology, York.

Niederschlag, E., Pernicka, E., Seifert, T., and Bartelheim, M. (2003). The determination of lead isotope ratios by multiple collector ICP-MS: A case study of Early Bronze Age artefacts and their possible relation with ore deposits of the Erzgebirge. Archaeometry 45: 61-100.

Nielsen, E. H. (2014). A Late Bronze Age tin ingot from Sursee-Gammainseli (Kt. Luzern). Archäologisches Korrespondenzblatt 44: 177-193.

Northover, J. P. (1980). The analysis of Welsh Bronze Age metalwork. In Savory, H. (ed.), Guide Catalogue of the Bronze Age Collections, National Museum of Wales, Cardiff, pp. 229-243.

Northover, J. P. (1982). The exploration of the long-distance movement of bronze in Bronze and Early Iron Age Europe. Bulletin of the Institute of Archaeology 19: 45-72.

Northover, J. P. (1988). Alloy design in the Bronze Age metalwork. In Ellis-Jones, J. (ed.), Aspects of Ancient Mining and Metallurgy, University of North Wales, Bangor, pp. 44-54.

Northover, J. P. (1989). Properties and use of arsenic-copper alloys. In Hauptmann, A., Pernicka, E., and Wagner, G. A. (eds.), Old World Archaeometallurgy, Der Anschnitt, Beiheft 7, Deutsches BergbauMuseum, Bochum, pp. 111-118.

Northover, J. P., O'Brien, W., and Stos, S. (2001). Lead isotopes and metal circulation in Beaker/Early Bronze Age Ireland. Journal of Irish Archaeology 10: 25-48. 
Novaković, P., Horňák, M., Guermandi, M. P., Stäuble, H., Depaepe, P., and Demoule, J.-P. (eds.) (2016). Recent Developments in Preventive Archaeology in Europe, Ljubljana University Press, Ljubljana.

O'Brien, W. (2004). Ross Island: Mining, Metal and Society in Early Ireland, Bronze Age Studies 6, National University of Ireland, Galway.

O'Brien, W. (2015). Prehistoric Copper Mining in Europe: 5000-500 BC, Oxford University Press, Oxford.

Osborne, R. (2004). Hoards, votives, offerings: The archaeology of the dedicated object. World Archaeology 36: $1-10$.

Otto, H., and Witter, W. (1952). Handbuch der ältesten vorgeschichtlichen Metallurgie in Mitteleuropa, J. A. Barth, Leipzig.

Pare, C. F. (1999). Weights and weighing in Bronze Age central Europe. In Eliten in der Bronzezeit: Ergebnisse zweier Kolloquien in Mainz und Athen, Römisch-Germanisches Zentralmuseum Monographien 43, Verlag des Römisch-Germanischen Zentralmuseums, Mainz, pp. 421-514.

Pare, C. F. (ed.) (2000). Metals Make the World Go Round: The Supply and Circulation of Metals in Bronze Age Europe, Oxbow Books, Oxford.

Pare, C. F. (2013). Weighing, commodification and money. In Fokkens, H., and Harding, A. F. (eds.), The Oxford Handbook of the European Bronze Age, Oxford University Press, Oxford, pp. 508-527.

Parzinger, H., and Boroffka, N. (2003). Das Zinn der Bronzezeit in Mittelasien I: Die Siedlungs-Archäologischen Forschungen im Umfeld der Zinnlagerstätten, Archäologie in Iran und Turan 5, Deutsches Archäologisches Institut, Mainz.

Patterson, C. C. (1972). Silver stocks and losses in ancient and medieval times. The Economic History Review 25: 205-235.

Pearce, M. (2016). Archaeology and archaeometallurgy: Some unresolved areas in the interpretation of analytical data. STAR: Science \& Technology of Archaeological Research 2: 46-53.

Penhallurick, R. D. (1986). Tin in Antiquity, The Institiute of Metals, London.

Pernicka, E. (1984). Instrumentelle Multi-Elementanalyse archäologischer Kupfer- und Bronzeartefakte: Ein Methodenvergleich. Jahrbuch des Römisch-Germanischen Zentralmuseums Mainz 31: 517-531.

Pernicka, E. (1987). Erzlagerstätten in der Ägäis und ihre Ausbeutung im Altertum: Geochemische Untersuchungen zur Herkunftsbestimmung archäologischer Metallobjekte. Jahrbuch des RömischGermanischen Zentralmuseums Mainz 34: 607-714.

Pernicka, E. (1989). Zur Probennahme von archäologischen Metallobjekten. Arbeitsblätter für Restauratoren 1: $138-148$.

Pernicka, E. (1990). Gewinnung und Verbreitung der Metalle in prähistorischer Zeit. Jahrbuch des Römisch-Germanischen Zentralmuseums Mainz 37: 21-129.

Pernicka, E. (1999). Trace element fingerprinting of ancient copper: A guide to technology or provenance? In Young, S. M. M., Pollard, A. M., Budd, P., and Ixer, R. A. (eds.), Metals in Antiquity, BAR International Series 792, Archaeopress, Oxford, pp. 163-171.

Pernicka, E. (2014). Provenance determination of archaeological metal objects. In Roberts, B. W., and Thornton, C. P. (eds.), Archaeometallurgy in Global Perspective: Methods and Syntheses, Springer, New York, pp. 239-268.

Pernicka, E., Begemann, F., and Schmitt-Strecker, S. (1993). Eneolithic and Early Bronze Age copper artefacts from the Balkans and their relation to Serbian copper ores. Prähistorische Zeitschrift 68: $1-54$.

Pernicka, E., Begemann, F., Schmitt-Strecker, S., and Grimanis, A. P. (1990). On the composition and provenance of metal artefacts from Poliochni on Lemnos. Oxford Journal of Archaeology 9: $263-298$.

Pernicka, E., Begemann, F., Schmitt-Strecker, S., Todorova, H., and Kuleff, I. (1997). Prehistoric copper in Bulgaria: Its composition and provenance. Eurasia Antiqua 3: 41-180.

Pernicka, E., Lutz, J., and Stöllner, T. (2016a). Bronze Age copper produced at Mitterberg, Austria, and its distribution. Archaeologia Austriaca 100: 19-55.

Pernicka, E., Nessel, B., Mehofer, M., and Safta, E. (2016b). Lead isotope analyses of metal objects from the Apa Hoard and other Early and Middle Bronze Age items from Romania. Archaeologia Austriaca 100: 57-86.

Pernicka, E., Seeliger, T. C., Wagner, G. A., Begemann, F., Schmitt-Strecker, S., Eibner, C., Öztunalı, O., and Baranyi, I. (1984). Archäometallurgische Untersuchungen in Nordwestanatolien. Jahrbuch des Römisch-Germanischen Zentralmuseums Mainz 31: 533-599. 
Pernicka, E., and Wunderlich, C.-H. (2017). Rezensionen: Rupert Gebhard und Rüdiger Krause: Bernstorf. Archäologisch-naturwissenschaftliche Analysen der Gold- und Bernsteinfunde vom Bernstorfer Berg bei Kranzberg, Oberbayern. Praehistorische Zeitschrift 92(2): 428-444.

Perucchetti, L., Bray, P., Dolfini, A., and Pollard, A. M. (2015). Physical barriers, cultural connections: Prehistoric metallurgy across the alpine region. European Journal of Archaeology 18: 599-632.

Pétrequin, P., Cassen, S., Errera, M., Klassen, L., Sheridan, A., and Pétrequin, A.-M. (eds.) (2012). JADE: Grandes Haches Alpines du Néolithique Européen: Ve et IVe millénaires av. J.-C, Presses Universitaires de Franche-Comté and Centre de Recherche Archéologique de la Vallée de l'Ain, Besançon.

Philip, G. (1988). Hoards of the Early and Middle Bronze Ages in the Levant. World Archaeology 20: 190-208.

Pittioni, R. (1957). Urzeitlicher Bergbau auf Kupfererz und Spurenanalyse: Beiträge zum Problem der Relation Lagerstätte-Fertigobjekt, Archaeologia Austriaca Beiheft 1, Archiv für Ur- und Frühgeschichtliche Bergbauforschung 10, Deuticke, Wien.

Pollard, A. M., and Bray, P. (2014). Chemical and isotopic studies of ancient metals. In Roberts, B. W., and Thornton, C. P. (eds.), Archaeometallurgy in Global Perspective: Methods and Syntheses, Springer, New York, pp. 217-238.

Pollard, A. M., Bray, P., Gosden, C., Wilson, A., and Hamerow, H. (2015). Characterising copper-based metals in Britain in the first millennium AD: A preliminary quantification of metal flow and recycling. Antiquity 89: 697-713.

Pollard, A. M., Bray, P., Hommel, P., Hsu, C. Y., Liu, R., and Rawson, J. (2017a). 利用牛津㗏究体系深 化对中国青铜器的认识: Applying the Oxford System to further understand bronzes in China 考 古 Kaogu 2017(1): 95-106.

Pollard, A. M., Bray, P., Hommel, P., Hsu, Y. K., Liu, R., and Rawson, J. (2017b). Bronze Age metal circulation in China. Antiquity 91: 674-687.

Pollard, A. M., and Bray, P. J. (2015). A new method for combining lead isotope and lead abundance data to characterize archaeological copper alloys. Archaeometry 57: 996-1008.

Pollard, A. M., Bray, P. J., and Gosden, C. (2014). Is there something missing in scientific provenance studies of prehistoric artefacts? Antiquity 88: 625-631.

Popov, H., Jockenhövel, A., and Groer, C. (2011). Ada Tepe (Ost-Rhodopen, Bulgarien): Spätbronzezeitlicher- ̈̈ltereisenzeitlicher Goldbergbau. Kampagne 2008. In Yalçın, Ü. (ed.), Anatolian Metal V, Der Anschnitt, Beiheft 24, Deutsches Bergbau-Museum, Bochum, pp. 111-126.

Primas, M., and Pernicka, E. (1998). Der Depotfund von Oberwilflingen. Germania 76: 25-65.

Pulak, C. (1998). The Uluburun shipwreck: An overview. International Journal of Nautical Archaeology 27: $188-224$.

Pulak, C. (2010). Uluburun shipwreck. In Cline, E. H. (ed.), The Oxford Handbook of the Bronze Age Aegean (ca. 3000-1000 BC), Oxford University Press, Oxford, pp. 862-876.

Rademakers, F. W., and Rehren, Th. (2016). Seeing the forest for the trees: Assessing technological variability in ancient metallurgical crucible assemblages. Journal of Archaeological Science: Reports 7: 588-596.

Radivojević, M., and Grujić, J. (2017). Community structure of copper supply networks in the prehistoric Balkans: An independent evaluation of the archaeological record from the 7th to the 4th millennium BC. Journal of Complex Networks 6: 106-124.

Radivojević, M., Pendić, J., Srejić, A., Korać, M., Davey, C., Benzonelli, A., Martinón-Torres, M., Jovanović, N., and Kamberović, Ž. (2017). Experimental design of the Cu-As-Sn ternary colour diagram. Journal of Archaeological Science 90: 106-119.

Radivojević, M., and Rehren, Th. (2016). Paint it black: The rise of metallurgy in the Balkans. Journal of Archaeological Method and Theory 23: 200-237.

Radivojević, M., Rehren, Th., Pernicka, E., Šljivar, D., Brauns, M., and Borić, D. (2010). On the origins of extractive metallurgy: New evidence from Europe. Journal of Archaeological Science 37: 2775-2787.

Rahmstorf, L. (2010). The concept of weighing during the Bronze Age in the Aegean, the Near East and Europe. In Morley, I., and Renfrew, A. C. (eds.), The Archaeology of Measurement: Comprehending Heaven, Earth and Time in Ancient Societies, Cambridge University Press, Cambridge, pp. $88-105$.

Rahmstorf, L. (2011). Re-integrating 'diffusion': The spread of innovations among the Neolithic and Bronze Age Societies in Europe and the Near East. In Wilkinson, T. C., Sherratt, S., and Bennet, J. 
(eds.), Interweaving Worlds: Systemic Interactions in Eurasia, 7th to the 1st millennia BC, Oxbow, Oxford, pp. 100-119.

Rassmann, K. (2011). Metallverbrauch in der frühen Bronzezeit Mitteleuropas: Produktion, Zirkulation und Konsumption frühbronzezeitlicher Metallobjekte als Untersuchungsgegenstände einer archäologischen Wirtschaftsgeschichte. In Hansen, S., and Müller, J. (eds.), Sozialarchäologische Perspektiven: Gesellschaftlicher Wandel 5000-1500 v.Chr. zwischen Atlantik und Kaukausus, Arch. Eurasien 24, DAI and Verlag Philipp von Zabern, Berlin, pp. 341-363.

Rehren, Th. (2003). Crucibles as reaction vessels in ancient metallurgy. In Craddock, P. T., and Lang, J. (eds.), Mining and Metal Production Through the Ages, British Museum Press, London, pp. 207-215.

Rehren, Th. (2016). Another order for glass-Or, how much glass does Pharaoh need? In Franzmeier, H., Rehren, Th., and Schulz, R. (eds.), Mit archäologischen Schichten Geschichte schreiben. Festschrift für Edgar B. Pusch zum 70. Geburtstag, Forschungen in der Ramses-Stadt 10, Gerstenberg, Hildesheim, pp. 255-267.

Rehren, Th., and Pusch, E. B. (2012). Alloying and resource management in New Kingdom Egypt: The bronze industry at Qantir-Pi-Ramesse and its relationship to Egyptian copper sources. In Kassianidou, V., and Papasavvas, G. (eds.), Eastern Mediterranean Metallurgy and Metalwork in the Second Millennium BC: Conference in Honour of James D. Muhly, Nicosia, 10th-11th October 2009, Oxbow Books, Oxford, pp. 215-221.

Roberts, B. W., and Ottaway, B. S. (2003). The use and significance of socketed axes during the Late Bronze Age. European Journal of Archaeology 6: 119-140.

Rodríguez, D. A., Pavón Soldevila, I., Duque Espino, D. M., Ponce de León Iglesias, M., Hunt Ortiz, M. A., and Merideth, C. (2013). La explotación tartésica de la casiterita entre los ríos Tajo y Guadiana: San Cristóbal de Logrosán (Cáceres). Trabajos de Prehistoria 70: 95-113.

Rohl, B. M. (1996). Lead isotope data from the Isotrace Laboratory, Oxford: Archaeometry Data base 2, galena from Britain and Ireland. Archaeometry 38: 165-180.

Rohl, B. M., and Needham, S. P. (1998). The Circulation of Metal in the British Bronze Age: The Application of Lead Isotope Analysis, British Museum Occasional Papers 102, British Museum, London.

Rovira, S. (2002). Metallurgy and society in prehistoric Spain. In Ottaway, B. S., and Wager, E. (eds.), Metals and Society, BAR International Series 1061, Archaeopress, Oxford, pp. 5-20.

Rovira, S. (2004). Tecnología metalúrgica y cambio cultural en la prehistoria de la Península Ibérica Norba. Revista de Historia 17: 9-40.

Rovira, S. (2007). La producción de bronces en la prehistoria. In Molera, J., Farjas, J., Roura, P., and Pradell, T. (eds.), Avances en arqueometría: Actas Del VI Congreso Ibérico de Arqueometría 2005, Universidad de Girona, Girona, pp. 21-35.

Rovira, S., and Gómez Ramos, P. (2003). Las primeras etapas metalúrgicas en la Península Ibérica, 3 : Estudios metalográficos, Instituto Universitario Ortega y Gasset, Madrid.

Rovira, S., Montero, I., and Conseurgra, S. (1997). Las primeras etapas metalúrgicas en la Península Ibérica, I: Análisis de materiales, Instituto Universitario Ortega y Gasset, Madrid.

Sabatini, B. (2015). The As-Cu-Ni system: A chemical thermodynamic model for ancient recycling. Journal of Metals 67: 2984-2992.

Sabatini, S. (2016). Late Bronze Age oxhide and oxhide-like ingots from areas other than the Mediterranean: Problems and challenges. Oxford Journal of Archaeology 35: 20-45.

Saez, R., Nocete, F., Nieto, J. M., Capitan, M. A., and Rovira, S. (2003). The extractive metallurgy of copper from Cabezo Jure, Huelva, Spain: Chemical and mineralogical study of slags dated to the third millenium BC. Canadian Mineralogist 41: 627-638.

Sangmeister, E. (1971). Aufkommen der Arsenbronze in SO-Europa. In Garašanin, M., Benac, A., and Tasić, N. (eds.), Actes du VIIle Congrès International des Sciences Préhistoriques et Protohistoriques, Beograd, 9-15 Septembre 197, Union Internationale des Sciences Prehistoriques et Protohistoriques, Belgrade, pp. 131-138.

Schubert, M., and Pernicka, E. (2013). Die frühbronzezeitliche Kupferverarbeitung auf dem Buchberg im Unterinntal, Tirol, in Montanwerke Brixlegg AG. In Oeggl, K., and Schaffer, V. (eds.), Cuprum Tyrolense - 5550 Jahre Bergbau und Kupferverhüttung in Tirol, Montanwerke Brixlegg, Tirol, pp. $123-152$.

Seewald, B. (2017). Das Zentrallabor auf der Überholspur: 611 Spangenbarren in 8 Tagen analysiert! Metalluntersuchungen mittels mobiler Röntgenfluoreszenzanalyse. In Krause, H. R., and Kutscher, S. (eds.), Spangenbarrenhort Oberding, Schriften 2, Museum Erding, Erding, pp. 158-165. 
Shelmerdine, C. W. (ed.) (2008). The Cambridge Companion to the Aegean Bronze Age, Cambridge University Press, Cambridge.

Shennan, S. (1999). Cost, benefit and value in the organization of early European copper production. Antiquity 73: 352-363.

Sherratt, A. (2006). The Trans-Eurasian exchange: The prehistory of Chinese relations with the West. In Mair, V. H. (ed.), Contact and Exchange in the Ancient World, Hawaii University Press, Honolulu, pp. 123-135.

Stöllner, T. (2003). Mining and economy: A discussion of spatial organisations and structures of early raw material exploitation. In Stöllner, T., Körlin, G., Steffens, G., and Cierny, J. (eds.), Man and Mining, Studies in Honour of Gerd Weisgerber, Der Anschnitt, Beiheft 16, Deutsches BergbauMuseum, Bochum, pp. 415-446.

Stöllner, T., Samaschev, Z., Berdenov, S., Cierny, J., Doll, M., Garner, J., Gontscharov, A., Gorelik, A., Hauptmann, A., Rainer, H., Kusch, G. A., Merz, V., Riese, T., Sikorski, B., and Zickgraf, B. (2011). Tin from Kazakhstan: Steppe tin for the West? In Yalçın, Ü. (ed.), Anatolian Metal V, Der Anschnitt, Beiheft 24, Deutsches Bergbau-Museum, Bochum, pp. 231-251.

Stos-Gale, Z. A. (1989). Cycladic copper metallurgy. In Hauptmann, A., Pernicka, E., and Wagner, G. A. (eds.), Old World Archaeometallurgy, Der Anschnitt, Beiheft 7, Deutsches Bergbau-Museum, Bochum, pp. 279-293.

Stos-Gale, Z. A. (1992). The origin of metal objects from the Early Bronze Age site of Thermi on the island of Lesbos. Oxford Journal of Archaeology 11: 155-177.

Stos-Gale, Z. A. (1998). The role of Kythnos and other Cycladic islands in the origins of Early Minoan metallurgy. In Mendoni, L., and Mazarakis, A. (eds.), Meletimata 27, Kea-Kythnos: History and Archaeology: Proceeding of the Kea-Kythnos Conference, Kea June 1994, Diffusion de Broccard, Paris, pp. 717-736.

Stos-Gale, Z. A. (2000). Trade in metals in the Bronze Age Mediterranean: An overview of lead isotope data for provenance studies. In Pare, C. F. (ed.), Metals Make the World Go Round: The Supply and Circulation of Metals in Bronze Age Europe, Oxbow Books, Oxford, pp. 56-69.

Stos-Gale, Z. A. (2001). The development of Spanish metallurgy and copper circulation in prehistoric southern Spain. In Gómez Tubío, B., Respaldiza Galisteo, M. A., and Pardo Rodríguez, M. L. (eds.), III Congreso Nacional de Arqueometría, Universidad de Sevilla, Sevilla, pp. 445-456.

Stos-Gale, Z. A. (2015). Patterns of trade in Cypriot copper in the Bronze Age eastern Mediterranean revealed using data from Oxford Archaeological Lead Isotope Database (OXALID). In RosinskaBalik, K., Ochal-Czarnowicz, A., Czarnowicz, M., and Debowska-Ludwin, J. (eds.), Copper and Trade in the South-Eastern Mediterranean, BAR International Series 2753, Archaeopress, Oxford, pp. 111-153.

Stos-Gale, Z. A. (2016). Bronze Age metal sources and the movement of metals between the Aegean and Anatolia. In Bartelheim, M., Horejs, B., and Krauss, R. (eds.), Von Baden bis Troja, Ressourcennutzung, Metallurgie und Wissenstransfer: Eine Jubiläumsschrift für Ernst Pernicka, Oriental and European Archaeology, Vol. 3, Verlag Marie Leidorf GmbH, Rahden/Westf., pp. 375-398.

Stos-Gale, Z. A., Gale, N. H., and Gilmore, G. R. (1984). Early Bronze Age Trojan metal sources and Anatolians in the Cyclades. Oxford Journal of Archaeology 3: 23-44.

Stos-Gale, Z. A., Maliotis, G., Gale, N. H., and Annetts, N. (1997). Lead isotope characteristics of the Cyprus copper ore deposits applied to provenance studies of copper oxhide ingots. Archaeometry 39: $83-123$.

Sun, W.-D., Zhang, L.-P., Guo, J., Li, C.-Y., Jiang, Y.-H., Zartman, R. E., and Zhang, Z.-F. (2016). Origin of the mysterious Yin-Shang bronzes in China indicated by lead isotopes. Scientific Reports 6: 23304. https://doi.org/10.1038/srep23304.

Tadmor, M., Kedem, D., Begemann, F., Hauptmann, A., Pernicka, E., and Schmitt-Strecker, S. (1995). The Nahal Mishmar hoard from the Judean Desert: Technology, composition and provenance. Atiqot 27: 95-148.

Timberlake, S. (2009). Copper mining and metal production at the beginning of the British Bronze Age. In Clark, P. (ed.), Bronze Age Connections, Oxbow Books, Oxford, pp. 94-121.

Tykot, R. H. (2002). Chemical fingerprinting and source tracing of obsidian: The central Mediterranean trade in black gold. Accounts of Chemical Research 35: 618-627.

Tylecote, R. F. (1970). The composition of metal artifacts: A guide to provenance? Antiquity 44: 19-25.

Tylecote, R. F. (1976). A History of Metallurgy, The Metals Society, London. 
Tylecote, R. F., and Boydell, P. J. (1978). Experiments on copper smelting. In Rothenberg, B., Tylecote, R. F., and Boydell, P. J. (eds.), Chalcolithic Copper Smelting, Institute for Archaeo-Metallurgical Studies, London, pp. 27-49.

Tylecote, R. F., Ghaznavi, H. A., and Boydell, P. J. (1977). Partitioning of trace elements between the ores, fluxes, slags and metal during the smelting of copper. Journal of Archaeological Science 4: $305-333$.

Uckelmann, M., and Mödlinger, M. (eds.) (2011). Warfare in Bronze Age Europe: Manufacture and Use of Weaponry, Archaeopress, Oxford.

Valério, P., Monge Soares, A. M., Fátima Araújo, M., Silva, R. J. C., Porfírio, E., and Serra, M. (2014). Arsenical copper and bronze in Middle Bronze Age burial sites of southern Portugal: The first bronzes in southwestern Iberia. Journal of Archaeological Science 42: 68-80.

Vandkilde, H. (1996). From Stone to Bronze: The Metalwork of the Late Neolithic and Earliest Bronze Age in Denmark, Jutland Archaeological Society and Aarhus University Press, Aarhus.

Vandkilde, H. (2005). A biographical perspective on Ösenringe from the Early Bronze Age. In Kienlin, T. L. (ed.), Die Dinge als Zeichen: Kulturelles Wissen und Materielle Kultur, Habelt, Bonn, pp. 263-281.

Vandkilde, H. (2014). Breakthrough of the Nordic Bronze Age: Transcultural warriorhood and a Carpathian crossroad in the sixteenth century BC. European Journal of Archaeology 17: 602-633.

Vandkilde, H. (2016). Bronzization: The Bronze Age as pre-modern globalization. Praehistorische Zeitschrift 91: 103-123.

Vandkilde, H. (2017a). The Metal Hoard from Pile in Scania, Sweden: Place, Things, Time, Metals, and Worlds around 2000 BCE, The Swedish History Museum Studies and Aarhus University Press, Aarhus.

Vandkilde, H. (2017b). Small, medium, large: Globalisation perspectives on the Afro-Eurasian Bronze Age. In Hodos, T. (ed.), Routledge Handbook of Globalization and Archaeology, Routledge, London, pp. 506-521.

Vandkilde, H., Hansen, S., Kotsakis, K., Kristiansen, K., Müller, J., Sofaer, J., and Stig Sørensen, M.-L. (2015). Cultural mobility in Bronze Age Europe. In Suchowska-Ducke, P., Reiter, S. S., and Vandkilde, H. (eds.), Forging Identities: The Mobility of Culture in Bronze Age Europe: Report from a Marie Curie Project 2009-2012 with Concluding Conference at Aarhus University, Moesgaard 2012, Volume 1, BAR International Series 2771, Archaeopress, Oxford, pp. 5-37.

Vilaça, R. (2008). Reflexões em torno da presença mediterrânea no Centro do território português, na charneira do Bronze para o Ferro. In Celestino Pérez, S., Rafel, N., and Armada, X.-L. (eds.), Contacto cultural entre el Mediterráneo y el Atlántico (siglos XII-VIII ANE): La precolonización a debate, Escuela Española de Historia y Arqueología de Roma del CSIC, Madrid, pp. 371-400.

Walaszek, D., Senn, S., Faller, M., Philippe, L., Wagner, B., Bulska, E., and Ulrich, A. (2013). Metallurgical and chemical characterization of copper alloy reference materials within laser ablation inductively coupled plasma mass spectrometry: Method development for minimally-invasive analysis of ancient bronze objects. Spectrochimica Acta Part B-Atomic Spectroscopy 79-80: 17-30.

Wang, Q., Strekopytov, S., Roberts, B. W., and Wilkin, N. (2016). Tin ingots from a probable Bronze Age shipwreck off the coast of Salcombe, Devon: Composition and microstructure. Journal of Archaeological Science 67: 80-92.

Waterbolk, H. T., and Butler, J. J. (1965). Comments on the use of metallurgical analysis in prehistoric studies. Helinium 5: 227-251.

Webley, L., Vander Linden, M., Haselgrove, C., and Bradley, R. (eds.) (2012). Development-Led Archaeology in North-Western Europe, Oxbow, Oxford.

Weisgerber, G., and Pernicka, E. (1995). Ore mining in prehistoric Europe: An overview. In Morteani, G., and Northover, J. P. (eds.), Prehistoric Gold in Europe: Mines, Metallurgy, and Manufacture, Kluwer Academic, Dordrecht, pp. 159-182.

Wengrow, D. (2011). 'Archival' and 'sacrificial' economies in Bronze Age Eurasia: An interactionist approach to the hoarding of metals. In Wilkinson, T. C., Sherratt, S., and Bennet, J. (eds.), Interweaving Worlds: Systemic Interactions in Eurasia, 7th to 1st Millennia BC, Oxbow Books, Oxford, pp. 135-144.

Williams, A. (2015). Where did all the prehistoric copper go? Linking the Great Orme ores to Bronze Age metalwork. The Journal of the Great Orme Exploration Society 2015: 1-10.

Wiseman, R. (2018). Random accumulation and breaking: The formation of Bronze Age scrap hoards in England and Wales. Journal of Archaeological Science 90: 39-49. 
Yates, D., and Bradley, R. (2010). Still water, hidden depths: The deposition of Bronze Age metalwork in the English Fenland. Antiquity 84: 405-415.

Yener, K. A., Kulakoğlu, F., Yazgan, E., Kontani, R., Hayakawa, Y. S., Lehner, J. W., Dardeniz, G., Öztürk, G., Johnson, M., Kaptan, E., and Hacar, A. (2015). New tin mines and production sites near Kültepe in Turkey: A third-millennium BC highland production model. Antiquity 89: 596-612.

\section{Bibliography of Recent Literature}

Armada, X.-L., Rafel, N., and Montero Ruiz, I. (2008). Contactos precoloniales, actividad metalúrgica y biografías de objetos de bronce en la Península Ibérica. In Celestino, S., Rafel, N., and Armada, X.-L. (eds.), Contacto cultural entre el Mediterráneo y el Atlántico (siglos XII-VIII ANE): La precolonización a debate, Serie Arqueológica 11, Escuela Española de Historia y Arqueología en Roma-CSIC, Madrid, pp. 465-508.

Armbruster, B. (2013). Gold and gold working in the Bronze Age. In Fokkens, H., and Harding, A. F. (eds.), The Oxford Handbook of the European Bronze Age, Oxford University Press, Oxford, pp. 454-468.

Begemann, F., Schmitt-Strecker, S., and Pernicka, E. (1989). Isotopic composition of lead in early metal artefacts: Results, possibilities, and limitations. In Hauptmann, A., Pernicka, E., and Wagner, G. A. (eds.), Old World Archaeometallurgy, Der Anschnitt, Beiheft 7, Deutsches Bergbau-Museum, Bochum, pp. 269-278.

Berger, D., Pernicka, E., Nessel, B., Brügmann, G., Frank, C., and Lockhoff, N. (2014). Neue Wege zur Herkunftsbestimmung des bronzezeitlichen Zinns. Blickpunkt Archäologie 4: 76-82.

Bourgarit, D., Rostan, P., Carozza, L., and Mille, B. (2010). Vingt ans de recherches à Saint-Véran, Hautes Alpes: État des connaissances de l'activité de production de cuivre à l'âge du Bronze ancient. Trabajos de Prehistoria 67: 269-285.

Brandherm, D. (2018). Fragmentation patterns revisited: Ritual and recycling in Bronze Age depositional practice. In Brandherm, D., Heymans, E., Hofmann, D., and Wells, N. (eds.), Gifts, Goods and Money: Comparing Currency and Circulation Systems in Past Societies, Archaeopress, Oxford, pp. 45-66.

Celestino, S., Rafel, N., and Armada, X.-L. (eds.) (2008). Contacto cultural entre el Mediterráneo y el Atlántico (siglos XII-VIII ane): La precolonización a debate (Serie Arqueológica 11), Escuela Española de Historia y Arqueología en Roma-CSIC, Madrid.

Diaz-Andreu, M., and Montero Ruiz, I. (1999). Arqueometalurgia de la provincia de Cuenca: Minería y metalurgia en la Edad del Bronce, Diputación Provincial de Cuenca, Cuenca.

Gale, N. H., and Stos-Gale, Z. A. (2007). Cross-cultural Minoan networks and the development of metallurgy in Bronze Age Crete. In La Niece, S., Hook, D., and Craddock, P. T. (eds.), Metals and Mines, Studies in Archaeometallurgy, Archetype Publications, London, pp. 103-111.

Gale, N. H., and Stos-Gale, Z. A. (2008). Changing patterns in prehistoric Cycladic metallurgy. In Brodie, N., Doole, J., Gavalas, G., and Renfrew, A. C. (eds.), Horizon: A Colloquium on the Prehistory of the Cyclades, McDonald Institute for Archaeological Research, Cambridge, pp. 387-408.

Gale, N. H., Stos-Gale, Z. A., Maliotis, G., and Annetts, N. (1997). Lead isotope data from the Isotrace Laboratory, Oxford: Archaeometry data base 4, ores from Cyprus. Archaeometry 39: 237-246.

Gauss, R. (2016). Früher Bergbau und Metallurgie auf der Iberischen Halbinsel 1: Zambujal und die Anfänge der Metallurgie in der Estremadura (Portugal): Technologie der Kupfergewinnung, Herkunft des Metalls und soziokulturelle Bedeutung der Innovation, Iberia Archaeologica 15/1, Wasmuth, Tübingen.

Giardino, C. (2002). I, Metalli nel mondo antico: Introduzione all'archeometallurgia (3rd edition), Laterza, Rome.

Gómez Ramos, P. (1997). Historiografía de la arqueometalurgia en España. Boletín de la Asociación Española de Amigos de la Arqueología 37: 139-150.

Groer, C. (2008). Früher Kupferbergbau in Westeuropa, Universitätsforschungen zur Prähistorischen Archäologie 157, Habelt, Bonn.

Haag, S., Popov, H., Horejs, B., Alexandrov, S., and Plattner, G. (eds.) (2017). Das erste Gold-Ada Tepe: Das älteste Goldbergwerk Europas, Kunsthistorisches Museum, Vienna. 
Hansen, S., Neumann, D., and Tilmann, V. (eds.) (2012). Hort und Raum: Aktuelle Forschungen zu bronzezeitlichen Deponierungen in Mitteleuropa, De Gruyter, Berlin.

Huelga-Suarez, G., Moldovan, M., Suárez Fernández, M., Ángel De Blas Cortina, M., and Ignacio García Alonso, J. (2014). Defining the lead isotopic fingerprint of copper ores from north-west Spain: The El Milagro mine (Asturias). Archaeometry 56: 88-101.

Huelga-Suarez, G., Moldovan, M., Suárez Fernández, M., de Blas Cortina, M. Á., and García Alonso, J. I. (2014). Isotopic composition of lead in copper ores and a copper artefact from the La Profunda mine (León, Spain). Archaeometry 56: 651-664.

Huelga-Suarez, G., Moldovan, M., Suárez Fernández, M., De Blas Cortina, M. Á., Vanhaecke, F., and García Alonso, J. I. (2012). Lead isotopic analyses of copper ores from the Sierra el Aramo (Asturias, Spain). Archaeometry 54: 685-697.

Hunt Ortiz, M., Contreras Cortés, F., and Arboledas Martínez, L. (2011). La procedencia de los recursos minerales en el poblado de la Edad de Bronce de Peñalosa (Baños de la Encina, Jaén): Resultados de análisis de isótopos de plomo. In Mata Perelló, J. M., Torró i Abat, L., Fuentes Prieto, M. N., Neira Campo, A., and Puche Riart, O. (eds.), Actas V Congreso Internacional sobre Minería y Metalurgia Históricas en el Suroeste Europeo (León, 2008): Libro en homenaje a C. Domergue, SEDPGYM, Madrid, pp. 290-310.

Hunt-Ortiz, M. A., Martínez Navarrete, M. I., Hurtado Pérez, V., and Montero-Ruiz, I. (2012). Procedencia de las puntas de jabalina del "Dolmen de la Pastora" (Valencina de la Concepción, Sevilla). Trabajos de Prehistoria 69: 357-374.

Kronz, A., Pernicka, E., and Simon, K. (2004). Naturwissenschaftliche Untersuchungen an der spätneolithischen Kupferaxt von Reiffenhausen. Archäologisches Korrespondenzblatt 34: 35-56.

Kuleff, I., and Pernicka, E. (1995). On the instrumental neutron activation analysis of native copper: some methodological considerations. Journal of Radioanalytical and Nuclear Chemistry 191: 145-161.

Lauermann, E., and Pernicka, E. (2013). Die frühbronzezeitlichen Barrendepotfunde aus Kilb, VB Melk und Obermarkersdorf, VB Hollabrunn Niederösterreich. In Bartelheim, M., Peška, J., and Turek, J. (eds.), From Copper to Bronze: Cultural and Social Transformations at the Turn of the 3rd/2nd Millennia BC in Central Europe: In Honour of Václav Moucha on his 80th Birthday, Beiträge zur Ur- und Frühgeschichte in Mitteleuropa 74, Beier \& Beran Archäologische Fachliteratur, Langenweissbach, pp. 147-164.

Liversage, D., and Pernicka, E. (2002). An industry in crisis? Copper alloy impurity patterns near the end of the Hungarian Bronze Age. In Jerem, E., and Biró, K. T. (eds.), Archaeometry 98, BAR International Series 1043, Volume II, Archaeopress, Oxford, pp. 417-431.

Lo Schiavo, F., Giumlia-Mair, A., Sanna, U., and Valera, R. (eds.) (2005). EPUISE-Archaeometallurgy in Sardinia from the Origin to the Beginning of Early Iron Age, Éditions Mergoil Montagnac.

Lutz, J., and Pernicka, E. (1996). Energy dispersive X-ray fluorescence analysis of ancient copper alloys: Empirical values for precision and accuracy. Archaeometry 38: 313-323.

Montero Ruiz, I. (1994). El origen de la metalurgia en el sureste peninsular, Instituto de Estudios Almerienses, Almeria.

Montero Ruiz, I. (ed.) (2010). Manual de arqueometalurgia, Museo Regional, Alcalá de Henares.

Montero Ruiz, I., and Murillo-Barroso, M. (2010). La producción metalúrgica en las sociedades argáricas y sus implicaciones sociales: Una propuesta de investigación. Menga 1: 37-52.

Montero Ruiz, I., Rafel, N., Hunt, M., Murillo-Barroso, M., Rovira, C., Armada, X.-L., and Graells, R. (2010). Pre-roman mining activities in the El Molar-Bellmunt-Falset district (Tarragonia, Spain): Indirect proofs based on lead isotopes analysis. In Anreiter, P., Goldenberg, G., Hanke, K., Krause, R., Leitner, W., Mathis, F., Nicolussi, K., Oeggl, K., Pernicka, E., Prast, M., Schibler, J., Schneider, I., Stadler, H., Stöllner, T., Tomedi, G., and Tropper, P. (eds.), Mining in European History and Its Impact on Environment and Human Societies: Proceedings for the 1st Mining in European History-Conference of the SFB-HIMAT, 12-15 November 2009, Innsbruck, Innsbruck University Press, Innsbruck, pp. 115-121.

Montero-Ruiz, I., Gallart, J., García-Vuelta, O., and Martínez-Navarrete, M. I. (2015). Homogénéité ou hétérogénéité dans le métal des dépôts de l’Âge du Bronze: Estimations sur leur formation à partir des isotopes du plomb. L’Anthropologie 119: 89-105.

Mordant, C., Gabillot, M., Krolikowski, F., and Saligny, L. (2004). Approche de la notion de flux de métal et de recyclage au sein des sociétés européennes de l'Âge du Bronze. In Lehoërff, A. (ed.), L'artisanat métallurgique dans les sociétés anciennes en Méditerranée occidentale: Techniques, lieux et forms de production: Actes du colloque de Ravello, 2-6 Mai 2000, École Française de Rome, Rome, pp. 263-285. 
Mordant, C., Pernot, M., and Rychner, V. (eds.) (1998). L'atelier du bronzier en Europe du xxe au viiie siècle avant notre ère, Volume 1: Les analyses de composition du métal: Leur apport à l'archéologie de l'Âge du Bronze: Actes du Colloque International Bronze' 96, Neuchâtel et Dijon, Mars 1996, CTHS, Paris.

Mordant, C., Pernot, M., and Rychner, V. (eds.) (1998). L'atelier du bronzier en Europe du xxe au viiie siècle avant notre ère, Volume 2: Du minerai au métal, du métal à l'objet: Actes du Colloque International Bronze’ 96, Neuchâtel et Dijon, Mars 1996, CTHS, Paris.

Mordant, C., Pernot, M., and Rychner, V. (eds.) (1998). L'atelier du bronzier en Europe du xxe au viiie siècle avant notre ère, Volume 3: Production, circulation et consommation du bronze: Actes du Colloque International Bronze' 96, Neuchâtel et Dijon, Mars 1996, CTHS, Paris.

Müller, R., and Pernicka, E. (2009). Chemical analyses in archaeometallurgy: A view on the Iberian Peninsula. In Kienlin, T. L., and Roberts, B. W. (eds.), Metals and Societies: Studies in Honour of Barbara S. Ottaway, Universitätsforschungen zur Prähistorischen Archäologie Bd. 169, Habelt, Bonn, pp. 296-306.

Murillo-Barroso, M., Montero-Ruiz, I., Rafel, N., Hunt Ortiz, M. A., and Armada, X.-L. (2016). The macro-regional scale of silver production in Iberia during the first millennium BC in the context of Mediterranean contacts. Oxford Journal of Archaeology 35: 75-100.

Needham, S. (2001). When expediency broaches ritual intention: The flow of metal between systemic and buried domains. Journal of the Royal Anthropological Institute 7: 275-298.

Nessel, B., Brügmann, G., and Pernicka, E. (2015). Tin isotopes and the sources of tin in the early Bronze age Únětice culture. In Mata-Perelló, J. M., Hunt Ortiz, M. A., and García, E. O. (eds.), Patrimonio geológico y minero: De la investigación a la difusión: Congreso en Memoria de Vicente Sos Baynat y Craig Merideth: Actas del XV Congreso Internacional sobre Patrimonio Geológico y Minero, SEDPGYM, Logrosán, Cáceres, pp. 1-20.

Pernicka, E. (1986). Provenance determination of metal artifacts: Methodological considerations. Nuclear Instruments and Methods in Physics Research Section B: Beam Interactions with Materials and Atoms 14: 24-29.

Pernicka, E. (1992). Evaluating lead isotope data: Comments on E. V. Sayre, K. A. Yener, E. C. Joel and I. L. Barnes, "Statistical evaluation of the presently accumulated lead isotope data from Anatolia and surrounding regions" III. Archaeometry 34: 322-326.

Pernicka, E. (1993). Comments on P. Budd, D. Gale, A. M. Pollard, R. G. Thomas and P. A. Williams, "Evaluating lead isotope data: Further observations" III. Archaeometry 35: 259-262.

Pernicka, E. (1995). Besprechung von F. Eckel: Studien zur Form- und Materialtypologie von Spangenbarren und Ösenringbarren: Zugleich ein Beitrag zur Frage der Relation zwischen Kupferlagerstätten, Halbzeugproduktion und Fertigwarenhandel. Germania 73: 174-183.

Pernicka, E. (1995). Crisis or catharsis in lead isotope analysis? Journal of Mediterranean Archaeology 8: $59-64$.

Pernicka, E. (1998). Whither metal analysis in archaeology? In Mordant, C., Pernot, M., and Rychner, V. (eds.), L'atelier du bronzier en Europe du Xxe au VIIIe siècle avant notre ère: Actes du Colloque International, "Bronze '96”, Neuchâtel et Dijon, 4-9 mars 1996, Comité des Traveaux Historiques et Scientifiques, Paris, pp. 259-267.

Pernicka, E. (2014). The development of metallurgy in western Anatolia, the Aegean and southeastern Europe before Troy. In Horejs, B., and Mehofer, M. (eds.), Western Anatolia before Troy-ProtoUrbanisation in the 4th Millennium BC? Proceedings of the International Symposium Held at the Kunsthistorisches Museum Wien, Vienna, Austria, 21-24 November, 2012, Oriental and European Archaeology, Vol. 1, Austrian Academy of Sciences Press, Vienna, pp. 447-461.

Pernicka, E., and Mehofer, M. (2013). Archäometallurgische Untersuchungen. In Lauermann, E., and Rammer, E. (eds.), Die Urnenfelderzeitlichen Metallhortfunde Niederösterreichs-Mit besonderer Berücksichtigung der zwei Depotfunde aus Enzersdorf im Thale, Universitätsforschungen zur Prähistorischen Archäologie, Band 226, Habelt, Bonn, pp. 42-59.

Rafel, N., Montero Ruiz, I., Castanyer, P., Aquilue, X., Armada, X.-L., Belarte, C., Fairen, S., Gasull, P., Gener, M., Graels, R., Hunt, M., Martin, A., Mata, J. M., Morell, N., Perez, A., Pons, E., Renzi, M., Rovira, M. C., Rovira, S., Santos, M., Tremoleda, J., and Villalba, P. (2010). New approaches on the Archaic trade in the north-eastern Iberian Peninsula: Exploitation and circulation of lead and silver. Oxford Journal of Archaeology 29: 175-202.

Santos Zalduegui, J. F., Garcia De Madinabeitia, S., Gil Ibarguchi, J. I., and Palero, F. (2004). A lead isotope database: The Los Pedroches Alcudia area (Spain): Implications for archaeometallurgical connections across south western and south eastern Iberia. Archaeometry 46: 625-634. 
Schmitt-Strecker, S., and Begemann, F. (2005). Kupfer- und bronzezeitliche Metallartefakte vom Westbalkan: Zur Frage nach den Quellen ihres Kupfers. Prähistorische Zeitschrift 80: 49-64.

Schreiner, M. (2007). Erzlagerstätten im Hrontal, Slowakei. Genese und Prähistorische Nutzung, Forschungen zur Archäometrie und Altertumswissenschaft, Band 3, Marie Leidorf, Rahden/Westf.

Simón García, J. L. (1998). La metalurgia prehistórica valenciana, Serie de Trabajos Varios 93, Museo de Prehistoria de Valencia, Valencia.

Stockhammer, P. W., Massy, K., Knipper, C., Friedrich, R., Kromer, B., Lindauer, S., Radosavljević, J., Pernicka, E., and Krause, J. (2015). Kontinuität und Wandel vom Endneolithikum zur frühen Bronzezeit in der Region Augsburg. In Meller, H., Arz, H. W., Jung, R., and Risch, R. (eds.), 2200 BC-Ein Klimasturz als Ursache für den Zerfall der Alten Welt? 7th Archaeological Conference of Central Germany, October 23-26, 2013 in Halle (Saale), Tagungen des Landesmuseums für Vorgeschichte Halle (Saale) Band 12, pp. 617-641.

Stos-Gale, Z. A., and Gale, N. H. (1994). The origin of metals excavated on Cyprus. In Knapp, A. B., and Cherry, J. (eds.), Provenance Studies and Bronze Age Cyprus: Production Exchange and PoliticoEconomic Change, Prehistory Press, Madison, WI, pp. 92-122, 210-216.

Stos-Gale, Z. A., Gale, N. H., and Annetts, N. (1996). Lead isotope analyses of ores from the Aegean. Archaeometry 38: 381-390.

Stos-Gale, Z. A., Gale, N. H., Annetts, N., Todorov, T., Lilov, P., Raduncheva, A., and Panayotov, I. (1998). Lead isotope data from the Isotrace Laboratory, Oxford: Archaeometry data base 5, ores from Bulgaria. Archaeometry 40: 217-226.

Stos-Gale, Z. A., Gale, N. H., Houghton, P. J., and Speakman, R. J. (1995). Lead isotope data from the Isotrace Laboratory, Oxford: Archaeometry data base 1, ores from the western Mediterranean. Archaeometry 37: 407-415.

Stos-Gale, Z. A., Hunt Ortiz, M. A., and Gale, N. H. (1999). Análisis elemental y de isótopos de plomo de objetos metálicos de los sondeos de Gatas. In Castro, P., Chapman, R., Gili, S., Lull, V., Micó, R., Rihuete, C., Risch, R., and Sanahuja Y., M. E. (eds.), Proyecto Gatas 2: La dinámica arqueoecológica de la ocupación prehistórica, Consejería de Cultura de la Junta de Andalucía, Sevilla, pp. 347-361.

Stos-Gale, Z. A., Kayafa, M., and Gale, N. H. (1999). The origin of metals from the Bronze Age site of Nichoria. Opuscula Atheniensia 24: 99-120.

Stos-Gale, Z. A., Maliotis, G., and Gale, N. H. (1998). A preliminary survey of the Cypriot slag heaps and their contribution to the reconstruction of copper production on Cyprus. In Rehren, Th., Hauptmann, A., and Muhly, J. (eds.), Metallurgica antiqua: In Honour of Hans-Gert Bachmann and Robert Maddin, Der Anschnitt, Beiheft 8, Deutsches Bergbau-Museum, Bochum, pp. 235-262.

Strahm, C. (1995). Die Anfänge der Metallurgie in Mitteleuropa. Helvetia Archaeologica 25: 2-39.

Tornos, F., and Chiaradia, M. (2004). Plumbotectonic evolution of the Ossa Morena zone, Iberian Peninsula: Tracing the influence of mantle-crust interaction in ore-forming processes. Economic Geology 99: 965-985.

Wilczek, J., Monna, F., Gabillot, M., Navarro, N., Rusch, L., and Chateau, C. (2015). Unsupervised model-based clustering for typological classification of Middle Bronze Age flanged axes. Journal of Archaeological Science: Reports 3: 381-391.

\title{
Affiliations
}

Miljana Radivojević1,5 $\cdot$ Benjamin W. Roberts ${ }^{2}$ - Ernst Pernicka ${ }^{3}$. Zofia Stos-Gale ${ }^{4}$ Marcos Martinón-Torres ${ }^{1,5}$ - Thilo Rehren ${ }^{5,6} \cdot$ Peter Bray $^{7}$. Dirk Brandherm ${ }^{8}$. Johan Ling ${ }^{4}$. Jianjun Mei $^{1} \cdot$ Helle Vandkilde $^{9}$. Kristian Kristiansen ${ }^{4}$. Stephen J. Shennan ${ }^{5}$. Cyprian Broodbank ${ }^{1}$

\author{
Ernst Pernicka \\ ernst.pernicka@cez-archaeometrie.de \\ Zofia Stos-Gale \\ zofia@stos-gale.com
}


Marcos Martinón-Torres

m.martinon-torres@ucl.ac.uk

Thilo Rehren

th.rehren@ucl.ac.uk; th.rehren@cyi.ac.cy

Peter Bray

peter.bray@rlaha.ox.ac.uk

Dirk Brandherm

d.brandherm@qub.ac.uk

Johan Ling

johan.ling@archaeology.gu.se

Jianjun Mei

Jianjun.Mei@nri.cam.ac.uk

Helle Vandkilde

farkhv@cas.au.dk

Kristian Kristiansen

kristian.kristiansen@archaeology.gu.se

Stephen J. Shennan

s.shennan@ucl.ac.uk

Cyprian Broodbank

cb122@cam.ac.uk

1 McDonald Institute for Archaeological Research, University of Cambridge, Downing Street, Cambridge CB2 3ER, UK

2 Department of Archaeology, Durham University, South Road, Durham DH1 3LE, UK

3 Curt-Engelhorn-Zentrum für Archäometrie, D6, 68159 Mannheim, Germany

4 Department of Archaeology and Ancient History, University of Gothenburg, Box 200, 40530 Göteborg, Sweden

5 Institute of Archaeology, University College London, 31-34 Gordon Square, London WC1H 0PY, UK

6 Science and Technology in Archaeology Research Center, The Cyprus Institute, Nicosia, Cyprus

7 School of Archaeology, University of Oxford, 1 South Parks Road, Oxford OX1 3TG, UK

8 School of Natural and Built Environment, Queen's University, University Road, Belfast BT7 1NN, UK

9 Department of Archaeology and Heritage Studies, Aarhus University, Moesgård Allé 20, 8270 Højbjer, Denmark 